\title{
SEISMIC INTERPRETATION AND CLASSIFICATION OF \\ MUD VOLCANOES OF THE SOUTH CASPIAN BASIN, OFFSHORE AZERBAIJAN
}

\author{
A Thesis \\ by \\ MEHDI YUSIFOV \\ Submitted to the Office of Graduate Studies of \\ Texas A\&M University \\ in partial fulfillment of the requirements for the degree of \\ MASTER OF SCIENCE
}

August 2004

Major Subject: Geology 


\title{
SEISMIC INTERPRETATION AND CLASSIFICATION OF \\ MUD VOLCANOES OF THE SOUTH CASPIAN BASIN, OFFSHORE AZERBAIJAN
}

\author{
A Thesis \\ by \\ MEHDI YUSIFOV \\ Submitted to Texas A\&M University \\ in partial fulfillment of the requirements \\ for the degree of \\ MASTER OF SCIENCE
}

Approved as to style and content by:

Philip D. Rabinowitz

(Chair of Committee)

Tom Blasingame

(Member)

William R. Bryant

(Member)

Richard Carlson

(Head of Department)

August 2004

Major Subject: Geology 


\begin{abstract}
Seismic Interpretation and Classification of Mud Volcanoes of the South Caspian Basin, Offshore Azerbaijan. (August 2004)

Mehdi Yusifov, B.S., Azerbaijan State Oil Academy Chair of Advisory Committee: Dr. Philip D. Rabinowitz
\end{abstract}

Understanding the nature of mud volcanism, mechanisms of formation, types of eruptions and their relationship to the hydrocarbon systems provides important information about subsurface conditions and geological processes within the South Caspian Basin.

A 2D seismic grid in southeastern offshore Azerbaijan is used to define the areal distribution of mud volcanoes and to make a classification of the mud volcanoes based on characteristic seismic features. A detailed database for each determined mud volcano is constructed. Analysis of different parameters from this database shows that there is a high concentration of mud volcanoes in the southern part of the study area that coincides with subsurface structures within the basin. Mud volcanoes with low relief (several tens of meters) are mainly concentrated in the northeast. Mud volcanoes with large vertical relief (greater than $200 \mathrm{~m}$ ) are clustered in the southwest part of the basin. Mud volcano development in the South Caspian Basin is generally linked to faults, which in some instances are detached at the basement level. By using interpreted seismic surfaces the relative time of mud flows has been determined from the mud volcanoes. The cycles of mud volcano activity in the South Caspian Basin coincides with the time of high 
sedimentation rate, a regional contraction episode, and major stage for hydrocarbon generation. Mud volcano activity initiated in the Sabunchi-Syrakhany (lower Pliocene) and has increased in activity in upper Apsheron-Quaternary time.

Previous studies of the onshore mud volcanoes in Azerbaijan and the results from current work conclude that mud volcano formation within the South Caspian Basin is mainly controlled by tectonic forces and overpressured sediments. Mud volcano activity is not always related to the Maykop organic rich shale succession. It can occur at shallow depths by pressure breakthrough from any stratigraphic zone. 


\section{DEDICATION}

I would like to dedicate this manuscript to those whose support and care inspired me throughout all these years at Texas A\&M - my parents and Magdalena Vintrova. Without their love and understanding this contribution would not be possible. 


\section{ACKNOWLEDGEMENTS}

I want to express my special gratitude to Dr. Philip D. Rabinowitz for the support, dedication and honest belief in my success.

I acknowledge my committee members - Dr. Tom Blasingame and Dr. William Bryant for their encouragement during this study.

Special thanks to ExxonMobil Exploration Company for the help and data support for this project during my summer internship.

Also, my acknowledgments to the Caspian Geophysical and State Oil Company of Azerbaijan Republic for the release of required seismic lines. 


\section{TABLE OF CONTENTS}

Page

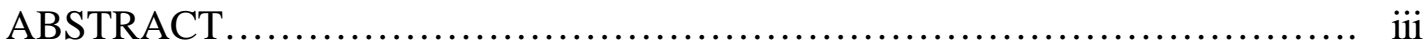

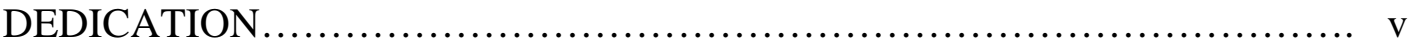

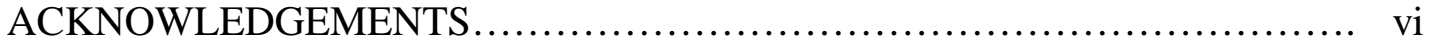

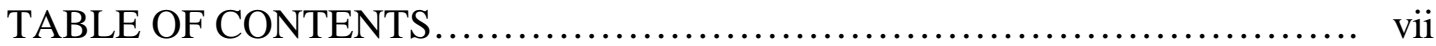

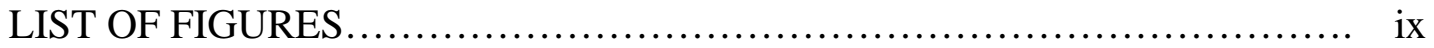

CHAPTER

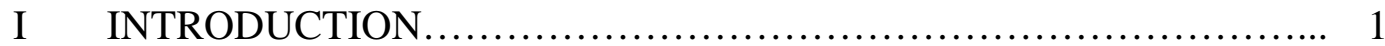

Methods and Procedures.................................... 3

Significance of the Study..................................... 4

II GEOLOGICAL BACKGROUND................................ 6

Tectonics............................................... 8

Stratigraphy.............................................. 14

Previous Studies of Mud Volcanoes............................ 20

III OBSERVATIONS AND RESULTS ................................ 26

Database Description...................................... 26

The Size.......................................... 26

Shape of the Mud Volcanoes............................ 29

Seismic Artifacts.................................. 33

Faulting and Relation to the Underlying Structure......... 35

Collapse Structure................................... 35

Mud Flows and Timing of Activity................... 38

Observations and Database Analysis.......................... 40

IV DISCUSSION AND CONCLUSIONS ............................. 59

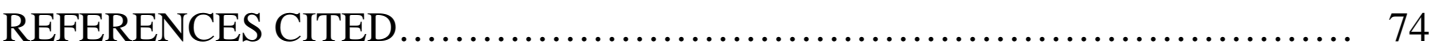

APPENDIX A.......................................................... 81 


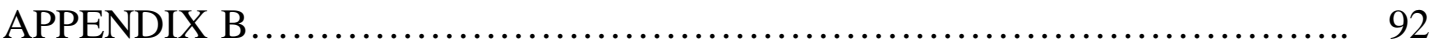

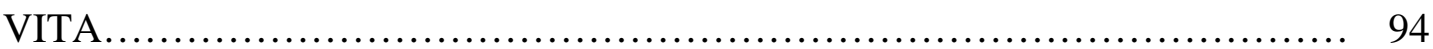




\section{LIST OF FIGURES}

FIGURE Page

$1 \quad$ Area of study with the $2 \mathrm{D}$ seismic data coverage $\ldots \ldots \ldots \ldots \ldots \ldots .2$

2 Summary structural map of the South Caspian Basin ........... 7

$3 \quad$ Crust and uppermost mantle cross-section between the Kura Basin to the west of the South Caspian Basin and the Turkmenian lowlands and the Kopeh Dag mountains to the east ...................................... 9

4 A schematic geological cross-section of the NE Talesh in Azerbaijan .............................................

$5 \quad$ Sketches to illustrate active tectonics of the South Caspian Basin ................................... 13

6 Generalized stratigraphic column for the Azeri sector of the South Caspian Basin ................................. 15

7 Diagram for the procedure of identifying the size of mud volcano............................................... 27

8 Diagram showing height extraction from the seismic data..........

9 Types of mud volcanoes based on the shape and appearance on the seismic line

10 Change in shape of a seismic response based on the place where the line intersects the mud volcano.

11 Examples of seismic artifacts associated with the mud volcanoes

12 Example of the mud volcano with faults in the vicinity 36

13 Example of the collapse structure before (a) and after (b) interpretation. 
16 a) Plot of the area versus height of the mud volcanoes;

b) height and c) area distribution from the obtained data population...

18 a) Areal distribution of the mud volcanoes of different shapes;

b) pie diagram reflecting distribution of the mud volcanoes with the specific shape...

a) Position of the mud volcanoes relative to subsurface structure; b) pie diagram reflecting distribution of the mud volcanoes relative to the subsurface structure

Mud volcano activity through time

21a Maps of mud volcano development in different periods of time: Activity in Subunchi-Upper Surakhany time (4.33 MY).

21b Maps of mud volcano development in different periods of time: Activity in Uppermost Surakhany time (3.5 MY)

21c Maps of mud volcano development in different periods of time: Activity in Upper Akchagyl time (2.3 MY).

21d Maps of mud volcano development in different periods of time: Activity in Upper Apsheron time (1.3 MY).

21e Maps of mud volcano development in different periods of time: Activity in Lower Quaternary time $(0.75 \mathrm{MY}) \ldots \ldots \ldots \ldots \ldots \ldots \ldots . \ldots 5$

21f Maps of mud volcano development in different periods of time: Activity in Upper Quaternary time $(0.3 \mathrm{MY}) \ldots \ldots \ldots \ldots \ldots \ldots \ldots .56$ 


\section{CHAPTER I}

\section{INTRODUCTION}

Mud volcanoes are a natural phenomena that has attracted attention for a long time. They have some similarities in appearance to magmatic volcanoes, but have greatly different origins. Mud volcanoes are key features that reflect regional geological processes in the Caspian Sea.

The Caspian Sea and surrounding regions, in particular Azerbaijan, have a long history relating to petroleum (Maksimova, 1987; Narimanov and Palaz, 1995; Abrams and Narimanov, 1997; Cullen, 1999; Daniloff, 1998; Sagers and Matzko, 1993). Stories abound with respect to the use of petroleum seeps in the $4^{\text {th }}$ century BC by soldiers of Alexander the Great. Marco Polo, when travelling on the Silk Route in the $13^{\text {th }}$ century, noted its great abundance (Rabinowitz et al, 2004). The very first oil exploration well ever drilled was in Baku, Azerbaijan in 1848, long before the first gushers in Texas and Arabia. The commercial production in the Baku area dates from the 1870's when the Russian government first allowed private development of the oil fields. By 1900, there were about 3000 oil wells and Azerbaijan accounted for $\sim 50 \%$ of the worlds oil production and in 1924 the first offshore well was drilled (Rabinowitz et al., 2004).

There are many global studies of mud volcanoes that reveal aspects of their origin, mechanism of formation and paleo-activity (Brown, 1990; Guliyev and

This thesis follows the style and format of the AAPG Bulletin. 


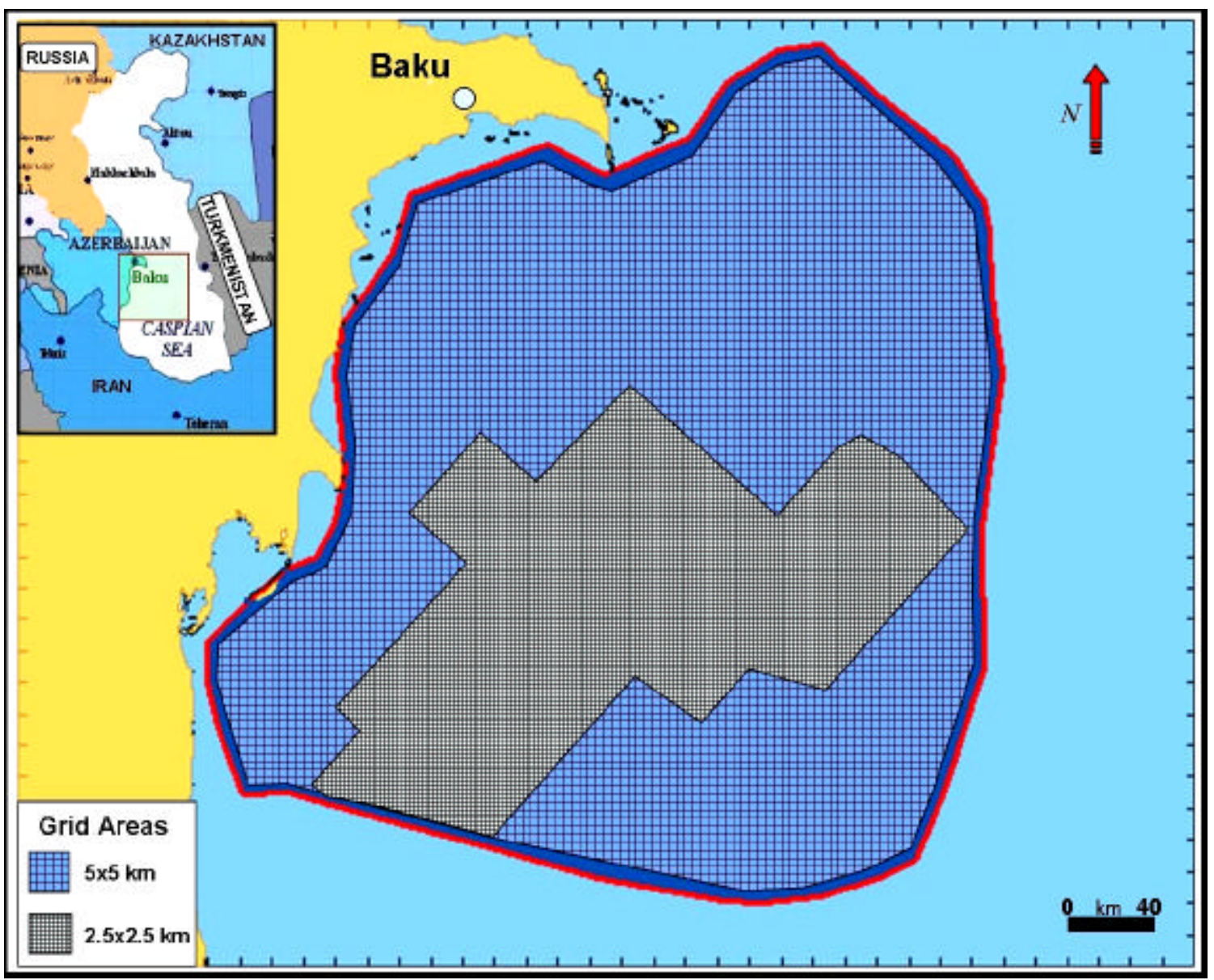

Figure 1. Area of study with the 2D seismic data coverage.

Feizullayev, 1995; Kopf, 2002; Milkov, 2000). Mud volcanoes are mainly concentrated in the systems of accretionary prisms where compressional settings and active fluid dynamics prevail. Thus, they are an important source of information about subsurface sediments and conditions.

The goal of this study is to interpret and classify mud volcanoes in the Caspian Sea using observations from 2D seismic data. In order to achieve this, a detailed database for all observed mud volcanoes is constructed. Next the database is analyzed 
and the relationship between the mud volcano occurrence and the regional geological settings is determined. Finally, these results and other major observations are combined with previous studies of mud volcanoes in the Caspian as well with studies of mud volcanoes in other regions of the globe.

This study provides a description of offshore mud volcanoes in an area of about $60,000 \mathrm{~km}^{2}$ southeast offshore Azerbaijan (Figure 1). The source of data is 2D seismic coverage that has been shot in 1995 and 1998. This seismic survey has extensively covered most of the Azeri sector of the Caspian Sea. The coarse grid between seismic lines is $5 \times 5 \mathrm{~km}$. In the central and southwestern portion of the study area the seismic line spacing is finer $-2.5 \times 2.5 \mathrm{~km}$ (Figure1). Since there is a paucity of geologic samples from the offshore areas where mud volcanoes are observed, the seismic data is vital for our understanding the processes and mechanisms of their formation.

\section{Methods and Procedures}

The mud volcanoes are characterized using seismic data by different assigned parameters (shape, height, relationship with the structure, existence of the faults, wipeout zones, etc.). Each parameter obtained from the seismic data were carefully documented and put into a database constructed in a Microsoft Excel spreadsheet. The database given in the appendix aid in obtaining a quantitative description of the assigned parameters.

The analysis of the database allows for the position of the mud volcanoes and their areal distribution to be mapped. Furthermore, the relative time of paleoflows (paleoactivity) from the mud volcanoes is identified. Wedge like features observed 
beneath the sea floor on the seismic reflection profiles are also mapped. These features are manifestation of mud volcano activity in the past.

\section{Significance of the Study}

More than $30 \%$ of the world's known mud volcanoes are concentrated in the South Caspian Basin (Guliyev and Feizullayev, 1995). Favorable tectonic conditions, depositional settings and thermobaric conditions caused generation of significantly huge mud volcanoes in this region (Guliyev and Feizullayev, 1995). In places, they are several kilometers across and reach several hundred meters in height (Appendix A). As a source of hydrocarbon gases they may provide sufficie nt supply of gases to the hydrosphere and atmosphere to possibly affect climate change (Kopf, 2002; Milkov, 2000). According to Guliyev (1995) the mud volcanoes may have a spatial and genetic relationship with oil and gas fields and thus may provide evidence of petroleum potential. This study shows that mud volcanoes are indeed located in regions where active hydrocarbon system are present, but are not necessary connected with fossil fuel accumulation. Mud volcanoes also impact drilling operations, rig installations and pipeline routings by their violent eruptions and instability of the surrounding gas saturated sediments (Milkov, 2000). Moreover, of particular interest to scholars as well as the petroleum industry is the answer to the question of what are mud volcanoes - are they conduits for charge of hydrocarbons to the reservoir rock or pathways to its leakage?

Observations from this study when integrated with the previous studies on mud volcanoes in the Caspian Sea show that there are no evidence of mud diapirs observed in 
the seismic data. Most mud volcanoes are situated above anticlines that are complicated by faults and there is a cyclicity in mud volcano development within an area of study. These conclusions also similar in part with conclusions of mud volcano studies in other geographical regions. 


\section{CHAPTER II}

\section{GEOLOGICAL BACKGROUND}

The South Caspian Basin is a Tertiary basin lying between the Greater and Lesser Caucasus and Talysh Mountains in Azerbaijan, and the Elburz and Koped Dag Mountains in Iran and Turkmenistan, respectively (Figure 2). It contains significant accumulations of oil and gas with discovered reserves estimated to be more than 20 GOEB (billion oil equivalent barrels) with an additional 20 plus GOEB undiscovered reserves. The South Caspian Basin a thus a world class petroleum system (Rabinowitz et al., 2004).

The South Caspian depression is characterized by a system of positive morphological elements reflecting subsurface Pliocene-Quaternary structures. These elements relate to the anticlinal folds extending from several tens of kilometers up to the 180-200 km (Croissant, 1998; Lebedev et al., 1987).

Extremely low values of geothermal gradient at the central part of the basin (1.0 to 1.8 deg.C/100m), compared to the values from the other basins $(2.5-3.5 \mathrm{deg} . \mathrm{C} / 100 \mathrm{~m})$ puts the present day limit for the "oil window" to about $9 \mathrm{~km}$ and the "gas window" to about 14 km (Guliyev and Feizullayev, 1995; Lerche et al., 1997; Nadirov et al., 1997).

High sedimentation rates up to $1000 \mathrm{~m} / \mathrm{MA}$ since middle Pliocene, as compared with other similar basins (100-200m/MA), causes excessive fluid pressure within the sediments throughout whole basin. Existence of overpressured sediments appears to be 


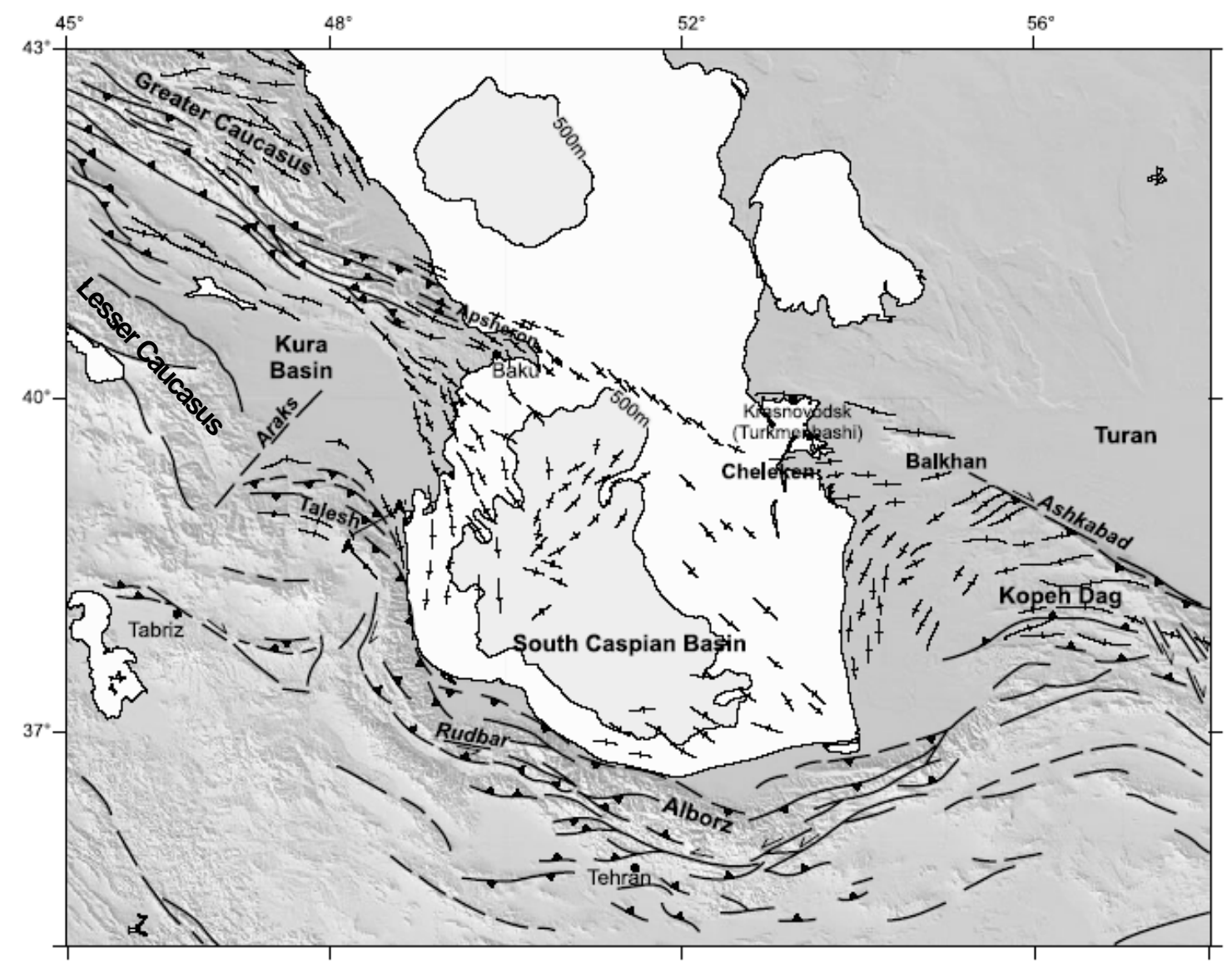

Figure 2. Summary structural map of the South Caspian Basin.

the key factor for the mud volcano formation and the mud volcanism in the basin (Lerche et al., 1997; Nadirov et al., 1997).

Hydrocarbon accumulations are mainly associated with structural traps. Variety of the anticlinal folds, monoclines with various degrees of reverse faulting and fracturing creates favorite conditions for the trapping hydrocarbons. However, mud volcanoes penetrate most of these structures. These are relatively large surface features, with an average height of $\sim 400$ meters and several kilometers in width. This large areal extent 
and unpredictable behavior is of obvious importance to the petroleum industry. The geological overview of this unique basin is described below.

\section{Tectonics}

The northern boundary of the South Caspian Basin is the Apsheron Sill that links the Apsheron and Cheleken peninsulas with a line of shallow anticlines (Allen et al., 2003). Its southern boundary lies parallel and just to the north of the Iranian coastline of the Caspian Sea. The eastern and western boundaries roughly correspond with the present day Caspian shorelines (Mangino and Priestley, 1998). Seismicity at the margins

of the South Caspian Basin shows that it is in the early stages of subducting under the Apsheron Sill to its north, where earthquakes acur at depth of up to $\sim 80 \mathrm{~km}$, and probably also under the Talysh to its west, where gently west-dipping thrust have depth of 15-27 km (Jackson et al., 2002).

Early works of Russian scientists, along with deep seismic sounding (DSS) experiments show that the crust of the South Caspian Basin is very different from that of the surrounding region (Jackson et al., 2002). Russian seismologists generally divide the continental crust into three main sections: a sedimentary layer, an upper or "granitic" crust bellow the sediments and a lower or "basaltic" crust. The DSS studies of the South Caspian Basin do not show "granitic" layer that is observed in the surrounding regions (Figure 3). Instead, the crust of the South Caspian Basin consists of a 15-25 km thick sedimentary layer with a Vp of $3.5-4.8 \mathrm{~km} \mathrm{~s}^{-1}$ overlying a $12-18 \mathrm{~km}$ thick "basaltic" layer with a Vp of 6.8-7.0 $\mathrm{km} \mathrm{s}^{-1}$ (Galperin et al., 1962; Neprochnov, 1968; Ryaboy, 

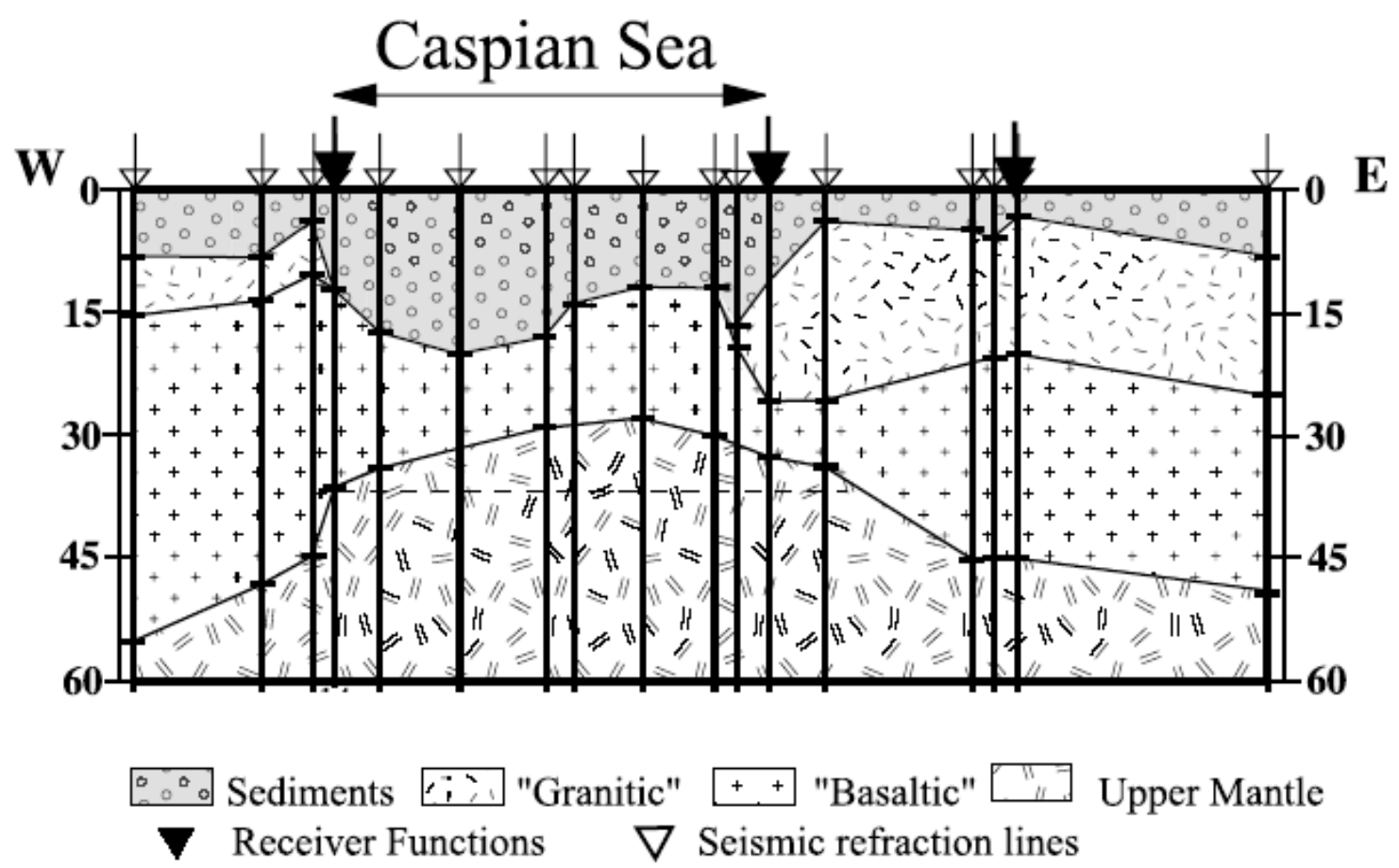

Figure 3. Crust and uppermost mantle cross-section between the Kura Basin to the west of the South Caspian Basin and the Turkmenian lowlands and the Kopeh Dag mountains to the east. The structure is summarized in terms of four generalized rock types: low-velocity sediments; the upper 'granitic' crust consisting of rocks with Vp 5.8-6.5 km/sec; the lower 'basaltic' crust consisting of rocks with $\mathrm{Vp} 6.5-7.8 \mathrm{~km} / \mathrm{sec}$; and the upper mantle. The vertical arrows at the top of the cross-section denote points where receiver function analysis (large solid arrows) or Russian refraction analysis (small open arrows), both from Mangino \& Priestley (1998), provide a constraint on the crustal structure. The surface wave study of Priestley \& Patton (2001) is for the path denoted by the double-headed arrow above the cross-section. The dashed line at $35 \mathrm{~km}$ depth beneath the basin denotes the approximate position of the Moho from the surface wave analysis. Adapted from Jackson et al., 2002.

1969; Yegorkin and Matushkin, 1970; Bulin, 1978; Khalilov et al., 1987). However, the thickness of this "basaltic" crust is not well constrained in the central part of the basin.

The tectonic evolution of the South Caspian Basin is quite complex with little agreement as to the origin of the anomalous south Caspian crust. Rezanov and Chamo 
(1969) and Shikalibeily and Grigoryants (1980) indicate that the region was uplifted during the Mesozoic by a mantle diapir and the upper continental crust was eroded. After this event was the period of subsidence and sedimentation. Berberian and King (1981) and Berberian (1983) suggest that the South Caspian Basin is either an unsubducted crustal remnant of an ocean that closed in the Triassic or Cretaceous, or a remnant of a marginal sea that developed behind an island arc in the late Mesozoic or Paleogene. Zonenshain and Le Pichon (1986) and Philip et al. (1989) argue that both the Black and Caspian seas are fragments of a larger, late Mesozoic back-arc basin which lies to the north of the late Mesozoic-Paleogene subduction zone of the Tethys Ocean. After the Tethys Ocean closed, the Red Sea Rift opened and as the Arabian plate moved northwards relative to the Eurasian plate, subduction shifted to the northern boundary of the marginal sea. Closure of this marginal sea $\sim 3.5 \mathrm{Ma}$ resulted in uplift and crustal thickening of the Caucasus and left relic oceanic crust underlying part of the Black Sea and South Caspian Basin. Sengor (1990) suggests that the South Caspian Basin opened as a large pull-apart structure along a major late Cretaceous strike-slip fault zone collinear with the Koped Dag - Alborz - Greater Caucasus montain belts.

The present day tectonics of the South Caspian Basin was also described in many sources. The recent analysis of the present active tectonics of the South Caspian Basin is presented by Jackson (2002) and Allen (2003). They suggest that lack of shallow earthquakes within the South Caspian Basin indicates that it behaves as a rigid block within the Eurasia-Iran-Arabia collision zone. Both this basement and sedimentary cover are markedly different from surrounding ranges, leading to major variations in the nature 


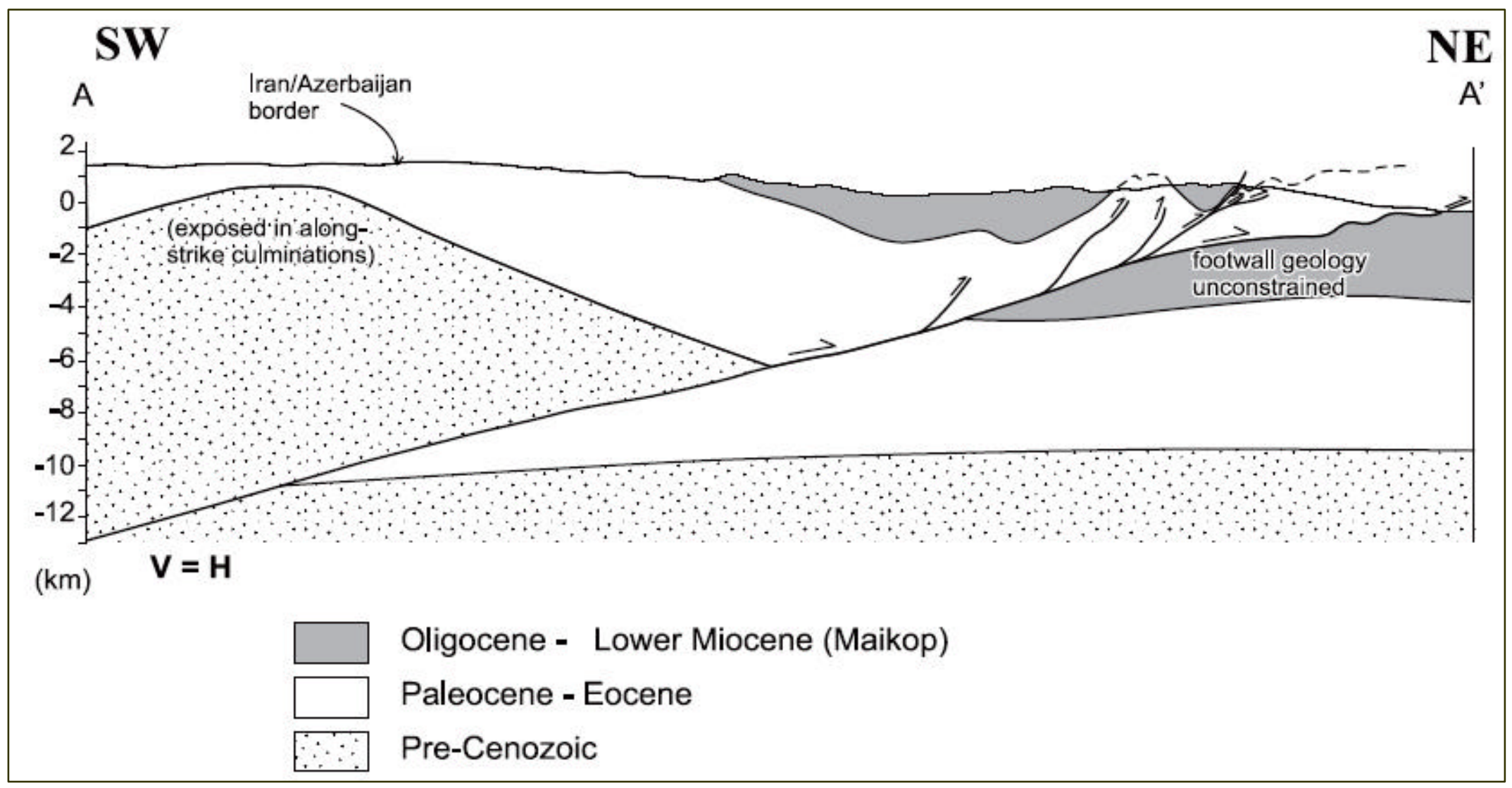

Figure 4. A schematic geological cross-section of the NE Talesh in Azerbaijan. The vertical and horizontal scales are equal. Adapted from Allen et al., 2003. 
and orientations of structures across the region. The South Caspian Basin is presently overthrust from all sides. At its margins, range-parallel strike-slip faults in the Alborz and Kopet Dagh indicate a westward motion of the South Caspian relative to both Iran and Eurasia. Earthquakes at up to $\sim 80 \mathrm{~km}$ beneath and north of the Apsheron Sill are consistent with the South Caspian basement subducting northwards (Allen, 2003). The surface folding is likely to be completely decoupled, and can be spatially separated from any basement shortening by the overpressured muds. The N-S folds in offshore Azerbaijan are probably a response to deeper basement shortening that occurs $\sim 100 \mathrm{~km}$ further west beneath the Talesh (Figure 4). Thus the Talesh takes up part of the regional Arabia-Eurasia convergence and also the westward motion of the South Caspian basement. The north-south shortening in the Talesh also means that the range moves northwards with respect to the adjacent South Caspian Basin. In contrast WNW-ESE trending surface folds near the Apsheron-Balkhan sill are probably a response to deeper thrusting of the Southern Caspian beneath the northern Caspian.

Figure 5 summarizes the active tectonics of the South Caspian Basin. The present day configuration (a) shows S to SW underthrusting in the Kopeh Dag, Alborz, Talesh and eastern Greater Caucasus and north dipping underthrusting in the central Caspian. A velocity triangle (b) illustrates the relative motion between Iran (I), Eurasia (E) and the South Caspian Basin (C). Sketch (c) illustrates how the current collinear geometry of the seismic belt across the Apsheron-Balkhan sill with the Caucasus and Kopeh Dag is unstable because the underthrusting is to the north in the middle (white triangles) but to 


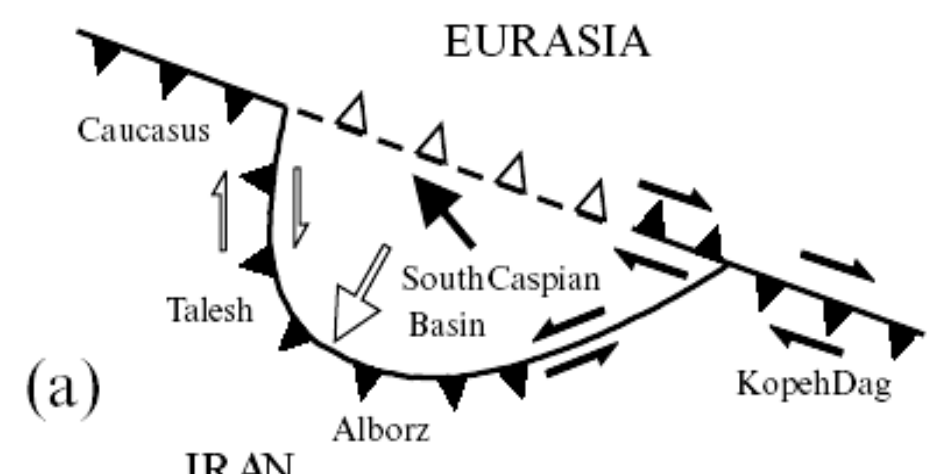

(b)

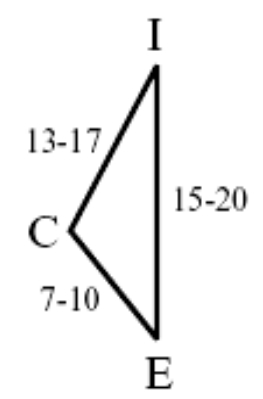

(c)

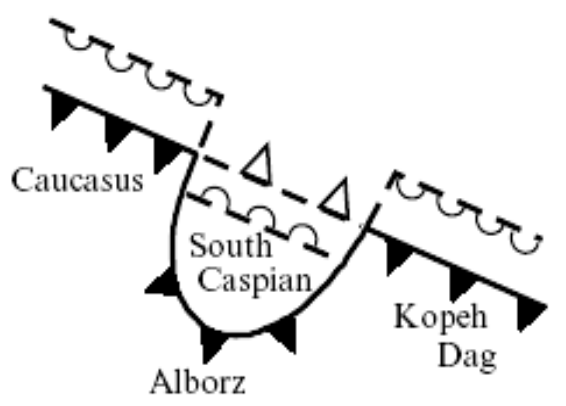

Figure 5. Sketches to illustrate active tectonics of the South Caspian Basin. (a) The present-day configuration, showing $S$ to SW underthrusting in the Kopeh Dag, Alborz, Talesh and eastern Greater Caucasus and north-dipping underthrusting in the central Caspian. Note the left-lateral strike-slip component in the eastern Alborz, and right-lateral component in the Kopeh Dag. The white arrow shows the approximate direction of the South Caspian Basin relative to Iran, and the black arrow shows its motion relative to Eurasia. (b) A velocity triangle constructed to illustrate the relative motion between Iran (I), Eurasia (E) and the South Caspian Basin (C). Velocities are in $\mathrm{mm}$ yrx1. (c) A sketch to illustrate how the current collinear geometry of the seismic belt across the Apsheron-Balkhan sill with the Caucasus and Kopeh Dag is unstable because the underthrusting is to the north in the middle (white triangles) but to the south on either side (black triangles). It will eventually evolve to the offset configuration shown by the white semi-circles. 
the south on either side (black triangles). It will eventually evolve to the offset configuration shown by the white semi circles.

The ability of the South Caspian basement to subduct under adjacent regions may lead to its eventual elimination. The South Caspian region especially demonstrates that a rigid block of crust within a collision zone may move with respect to adjacent areas millions of years after initial collision. As it moves, it produces deformation zones with kinematics that are not predictable from the overall plate convergence. The exact style in which deformation occurs depends strongly on the nature of the crust in each area, its

overall strength, pre-existing structures available for reactivation, and the stratigraphic horizons available to slip during thrusting (Allen, 2003).

\section{Stratigraphy}

The huge sedimentary cover in some instances up to $20 \mathrm{~km}$ thick contains sediments from Jurassic to Quaternary in age (Abrams and Narimanov, 1997). Typical source rock for the basin is the organic rich Maikop shales (Figure 6). These are mudprone sediments that lie at depths of 10-12 km within the basin interior. Their thickness, in some instances, reaches $8 \mathrm{~km}$. Outcrop studies showed the very high values for the total organic carbon (TOC) in these shales which together with other different geochemical parameters reveals its high generation potential (Abrams and Narimanov, 1997; Belopolsky et al., 1998; Buryakovky et al., 1995; Katz et al., 2000; Lerche et al., 1997). 


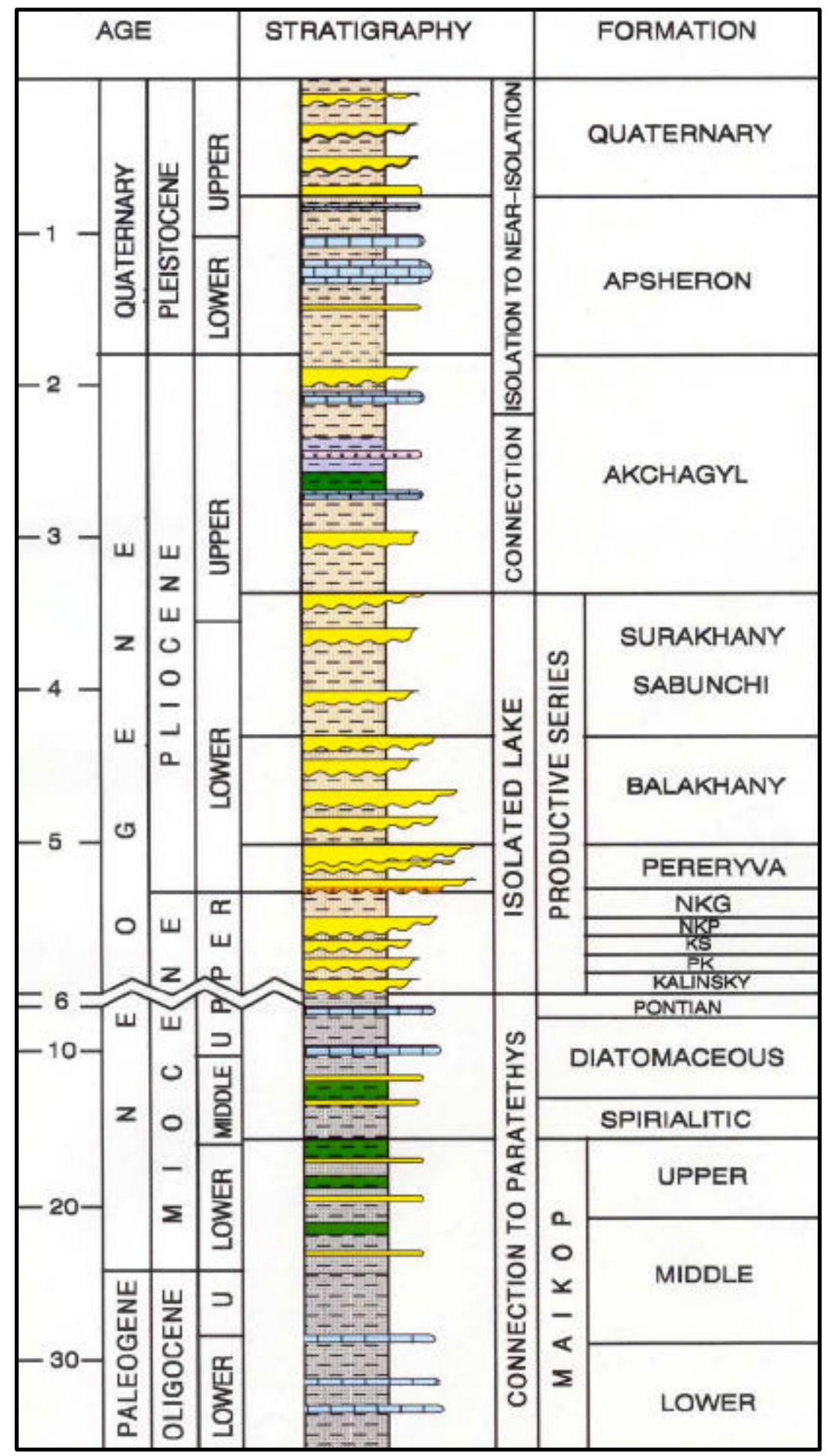

Figure 6. Generalized stratigraphic column for the Azeri sector of the South Caspian Basin. 
Younger strata record a broadly shallowing upward trend in the basin, which led to the late Miocene deposition of evaporites. The main oil reserves have been discovered in the Middle Pliocene Productive Series. Fluvial-deltaic deposition of the Productive Series and its lateral equivalents took place between the latest Miocene and the early Pliocene (Reynolds and Simmons, 1998). During this time highly incised paleo-Volga river system supplied sediment from the Russian Plain to the north, and the paleo-Amu Darya supplied sediment from the Pamirs to the east. Relatively minor sediment input came from other river systems, such as paleo-Kura and paleo-Sumgaiet. These rivers fed a series of lowstand lacustrine deltas. There are two distinctive groups of reservoir rocks within the Productive Series. One is the Early Productive series - mainly quartz and rocks typical for Paleo Volga deposits. The second is the Late Productive series - less quartz, more feldspar, and fragments of both sedimentary and volcanic rocks typical for Paleo-Kura sediments.

The following is a detailed description of the Productive Series based on the field work studies of several outcrops around Apsheron peninsula (Reynolds and Simmons, 1998). The Productive Series of the Absheron Peninsula is divided into several distinctive intervals or suites: Kalin Suite (KAS), Pre-Kirmaky Sand Suite (PK), Kirmaky Suite (KS), Post-Kirmaky Sand Suite (NKP), Post-Kirmaky Clay Suite (NKG), Pereriva Suite, Balakhany Suite, Sabunchy Suite, Surakhany Suite.

The area around Kirmaky Valley is the best place to examine exposures of the Productive series. This area lies in the center of the Apsheron Peninsula, $12 \mathrm{~km}$ north of Baku. Many of the sandstones are bitumen stained or oil bearing, and at the northern 
edge of the valley, there is a well-known and spectacular burning gas seep (Reynolds and Simmons, 1998). Outcrops of the older suites within the Productive series occur along the margins of a mud volcano in Kirmaky Valley. The strata comprise the PK, the KS, the NKP, the NKG, and the Pereriva Suite. The overlying Balakhany Suite and Sabunchi Suite are only poorly exposed in Kirmaky Valley. However, good exposures of these suites occur west of the main valley in a quarry identified as Balakhany Quarry, where $220 \mathrm{~m}$ of the Balakhany Suite is exposed, and good exposures occur along the side of an adjacent lake, where a wave-cut platform, exposes over $190 \mathrm{~m}$ of the Sabunchi Suite.

Kalin Suite is not exposed in any outcrops within the Absheron Peninsula. It is known from the numerous wells that breach this suite in different areas. Kalin Suite is presented by the coarse-grained succession more than 300 m thick.

The Pre-Kirmaky Sand Suite is poorly exposed at Kirmaky Valley (commonly covered by mud volcano flows). The sands are weak-sorted, medium and coarse grained, rarely fine-grained, and often cemented into the sandstones.

The Kirmaky Suite can be divided into a lower sand-prone unit and an upper argillaceous unit. Lower sand-prone unit that exposed at Kirmaky Valley consists of three stacked parasequences (9-15 m thick) bounded by abrupt flooding surfaces. The coarser grained and most laterally extensive sandstones occur at the top of each parasequence and interpreted as fluvially dominated, shoal water distributary mouth bars at the front of the paleo-Volga delta (Reynolds and Simmons, 1998). 
In Kirmaky Valley the Post-Kirmaky Sand Suite is around $150 \mathrm{~m}$ thick at outcrop. The basal sandstone passes upward into a succession of mudstones, siltstones, and sandstones arranged into coarsening-upward parasequences that range in thickness from 7 to $14 \mathrm{~m}$. As in the Kirmaky Suite, the coarsening-upward signatures are thought to record deposition on fluvially dominated mouth bars. The fining-upward successions, by contrast, are interpreted as the product of distributary channels that fed the prograding mouth bars.

The Post-Kirmaky Clay Suite is dominated by mudstone and siltstone with thin sandstone beds. These rock types are arranged into stacked coarsening-upward successions (9-15 m thick). The characteristics of the post-Kirmaky Clay Suite indicate low-energy conditions dominated by deposition of suspended fine-grained material. Micropaleontological studies of the samples from this suite show that deposition occurs in a low salinity, shallow-marine environment.

The Pereriva Suite is one of the most important producing intervals in the subsurface, particularly in the offshore where it is up to 110 m thick. In Kirmaky Valley, where only the basal $35 \mathrm{~m}$ of the Pereriva are well exposed, the suite is $100 \%$ sandstone and characterized in its lower portions by conglomeratic sandstones with clasts up to 10 $\mathrm{cm}$ in diameter. The grain-size decreases upward to very fine or fine-grained sandstone. These characteristics are interpreted to record a major fluvial or distributary channel system. The erosion surface and jump to coarser grade material that occur at the base of the Pereriva Suite are thought to reflect a drop in base level and are considered to record a major sequence boundary. 
The Balakhany Suit is the major producing interval in the offshore Apsheron Peninsula. The suite consists of fine-grained sandstone intervals and intervals of interbedded siltstone and sandstone. The sandstone intervals are predominantly fine grained, laterally extensive, and interpreted as stacked channels and proximal mouth bars. The interbedded siltstone and sandstone reflects delta-front and delta-plain deposition.

The Sabunchi Suite is an argillaceous succession. It is exposed west of Balakhany Quarry, and characterized by decimeter thick beds of mudstone, siltstone, and sandstone. Sandstone beds are either of constant grain size or fine upward. The overall succession is thought to be deposited in a distal delta-front setting (in case of thin sands interbeded with the siltstone) or in mouth bars and distributary channels environment (in case of thick sands).

The Surakhany Suite is the uppermost lithostratigraphic subdivision of the Productive series. It typically consists of mudstones, siltstones, and very thin, finegrained sandstones. This suite is not exposed in the Kirmaky Valley area. Good exposures of this suite exist at Yasamal Valley on the Apsheron Peninsula.

To summarize, the deposition of the Productive series was initiated by a major fall in base level during the latest Miocene (Reynolds and Simmons, 1998; Allen et al., 2003). The Paleo-Volga river brought the majority of sediments into the small, isolated South Caspian Basin. Over the Apsheron Peninsula the paleo-Volga river formed a major sandy braid delta. Fluctuations in sediment supply and in base level caused the delta to prograde, retrograde, and step abruptly basinward at a variety of scales. Four 
major facies associations show different reservoir quality and outline general characteristics of target horizons: (1) Alluvial Braided River, (2) Delta Plain, (3) Proximal Delta Front, and (4) Distal Delta Front facies associations (Reynolds and Simmons, 1998; Abdullayev, 2000). Each of these facies reflects different depositional environment and leads to different reservoir performance in the subsurface. Fluvial reservoirs are likely to have an excellent reservoir performance. In delta-plain deposits reservoir performance are likely to be poorer than that in fluvial system. Fine grained sands and interbedded siltstones along with the faulting affect dramatically on reservoir performance within the proximal delta-front deposits. Poorest reservoir quality has deposits of distal delta-front facies association. Very fine sands compartmentalized by faults and shale injections affect greatly on reservoir performance.

\section{Previous Studies of Mud Volcanoes}

Mud volcanism is an interesting and unusual natural phenomenon. It occurs in areas of tectonic compression and is usually associated with hydrocarbon accumulations in deep-seated strata. Three important aspects are (Milkov, 2000): (1) mud volcanoes may be an indication of high petroleum potential, (2) mud volcanoes are an important tool for obtaining information about subsurface sediments and conditions, (3) submarine mud volcanoes are may be hazardous for the drilling operations, rig installations and pipeline routings.

From a scientific point of view mud volcanoes offer an important source of information about subsurface conditions and environment. Proper use of this "natural 
well" allows us to evaluate types of hydrocarbons, build trap models, charge scenarios and define reservoir distribution.

More than $30 \%$ of the world's mud volcanoes are concentrated in the Azerbaijan region. Based on comprehensive studies by Azeri and Russian geologists, more than 300 mud volcanoes have been recognized both onshore and offshore Azerbaijan. Most are relatively large with an average height of $400 \mathrm{~m}$ with widths of several kilometers. However, as will be discussed, recent surveys indicate that the concentration of mud volcanoes offshore is higher than previously assumed.

There are several important conditions that are necessary for mud volcano formation (Milkov, 2000):

- thick sedimentary cover;

- the presence of plastic stratum in the subsurface;

- enough gas supply and high hydrocarbon potential;

- the rapid sedimentation rate and as a consequence of that abnormally high formation pressure;

- the occurrence of faults;

- compressional settings;

- seismicity.

Within the South Caspian Basin the sedimentary cover is about $20 \mathrm{~km}$. The source rock for hydrocarbon generation is the thick Mykop shale succession. It is highly overpressured. Overpressure of the sediments is caused by high sedimentation rate and subsidence in the Plio-Pleistocene $(>2.0 \mathrm{~km} / \mathrm{MA})$. Such high sedimentation causes the 
low heat flow within the basin. The region is tectonically very active. The basin is highly folded and faulted and the overall seismicity of the region is considerably high (Lerche et al., 1997). Therefore, the South Caspian Basin has the sufficient conditions that lead to mud volcano formation.

Many hypotheses were proposed in order to explain mechanism of mud volcano formation. One theory explains the formation of mud volcanoes due to rising of mud diapirs where gas supply and formation fluids is the driving forces for the mud volcanism (Brown, 1990; Guliyev and Feyzullayev, 1995; Kopf, 2002; Milkov, 2000). Another hypothesis, proposed by Lorenz (1975), explains the formation of the mud volcanoes due to rapid flow of pore fluids to the plastic shales and later escape of this highly fluidized mass through the faults or other structural conduits (Fowler et al., 2000). This theory does not associate the formation of the mud volcanoes with the mud diapirism. However, both concepts show the critical role of the gas and formation fluids in the mechanism of formation of the mud volcanoes.

From the studies of onshore mud volcanoes in Azerbaijan it is possible to conclude that:

- Mud volcano formation begins in the Middle Miocene and becomes more intensive in the Pliocene.

- Roots of many mud volcanoes onshore are Lower Cretaceous and Jurassic. The samples of these rocks have bitumen content from $0.469 \%$ up to $2.5 \%$.

- Gases of mud volcanoes consist primarily of methane with a little content of $\mathrm{CO} 2$ and heavy hydrocarbons. 
- Mineralization of the waters of mud volcanoes is the same as the waters of oil fields.

- The height and the form of mud volcanoes depend on their activity (frequency of eruption) and on the nature of material erupted.

- Mud volcanoes have little affect on the oil and gas distribution in the structures. They primarily affect as a seal, not as a conductor.

An interesting relationship has been found between the shape of the mud volcano and the material erupted. Volcanoes, which are not known for their powerful eruptions but are characterized by constant activity of gryphons and salses do not usually form distinct topographic highs, and sometimes simply merge into the surrounding plain. Their highest points are usually raised by only $10-20 \mathrm{~m}$, but they often cover an area of several square kilometers. The craters are up to $400 \mathrm{~m}$ in diameter, and the base of the volcano is usually hundreds of meters, and sometimes several kilometers across. On the other hand, material erupted has a very strong influence on the shape and height of the body of the mud volcano. More dense material has steeper slopes and greater heights.

Offshore areas of Azerbaijan have little in terms of geological samples. Therefore, the offshore seismic records are of special importance in correlating what is observed onshore to offshore (Fowler et al., 2000).

Potential hazards from the mud volcano eruption might be expulsion of mud, emission of toxic gases and spontaneous combustion of the gases (Guliyev and Feyzullayev, 1995). These hazardous phenomena can occur suddenly and without warning. They only affect the area directly near the mud volcanoes and therefore only 
pose a localized threat. However not all mud volcano eruptions are violent and dangerous. There are four basic groups of mud volcanoes as defined by State Oil Company of Azerbaijan Republic:

1. Explosive - powerful flow of mud and gas that spontaneously ignites.

2. Effusive - ejection of large amount of mud breccia with non-ignited gas emission.

3. Effusive - flow of low viscosity of mud without intense gas emissions.

4. Extrusive - slow extrusion of viscous mud with very insufficient amount of gas (Fowler, 2000).

Among these types of mud volcano eruptions, the first two can be very hazardous. Others have less destructive power and might be considerably predictable.

The South Caspian Basin is an important element in the Arabia-Eurasia collision. Being overthrust by continental material from all sides it behaves as a rigid block. The origin of this block is still controversial. It is either a remnant of oceanic lithosphere with unusual thick crust (Zonenshain et al., 1986; Philip et al., 1989) or stretched continental crust with unusually high velocity (Sengor, 1990). High sedimentation rate initiated during Upper Miocene - Early Pliocene time caused deposition of a very thick highly overpressured sedimentary succession. Silty sediments interbedded with the thick sand beds contain great amount of fluids as well as hydrocarbon gases. These extreme conditions such as overpressure, existence of plastic shale succession saturated with the fluids and high tectonic activity favors the mud volcano development in the region. Mud 
volcanism apparently plays very important role in the regional geology of the area as well as in many aspects of petroleum exploration. 


\section{CHAPTER III}

\section{OBSERVATIONS AND RESULTS}

\section{Database Description}

Using 2D seismic lines that cover most of the territory of Azeri sector of the Caspian Sea it is possible to determine the size, shape and seismic characteristic of the features that are interpreted as mud volcanoes. These observations are placed into a database constructed in Excel Spreadsheet format and presented in Appendix A. The database was created in order to capture any possible observations that might be relevant to the mud volcano and to reveal characteristics of mud volcanism in general. The description of the mud volcanoes was based on size, shape and seismic artifacts, such as wipeout zone, multiples and pulldown effect, and on relation to the faults and structures underneath the observed seismic features. In addition to this study, the data of the paleo flows from mud volcanoes is gathered and the time of their occurrence is determined. Detailed description of the database is provided below.

\section{The Size}

The procedure for estimating the size of the interpreted mud volcano is described. First the seismic line is examined for the existence of any indicators suggesting the existence of a mud volcano. This feature is marked by the arbitrary horizon that captures the entire extent of the mud volcano within this particular seismic 


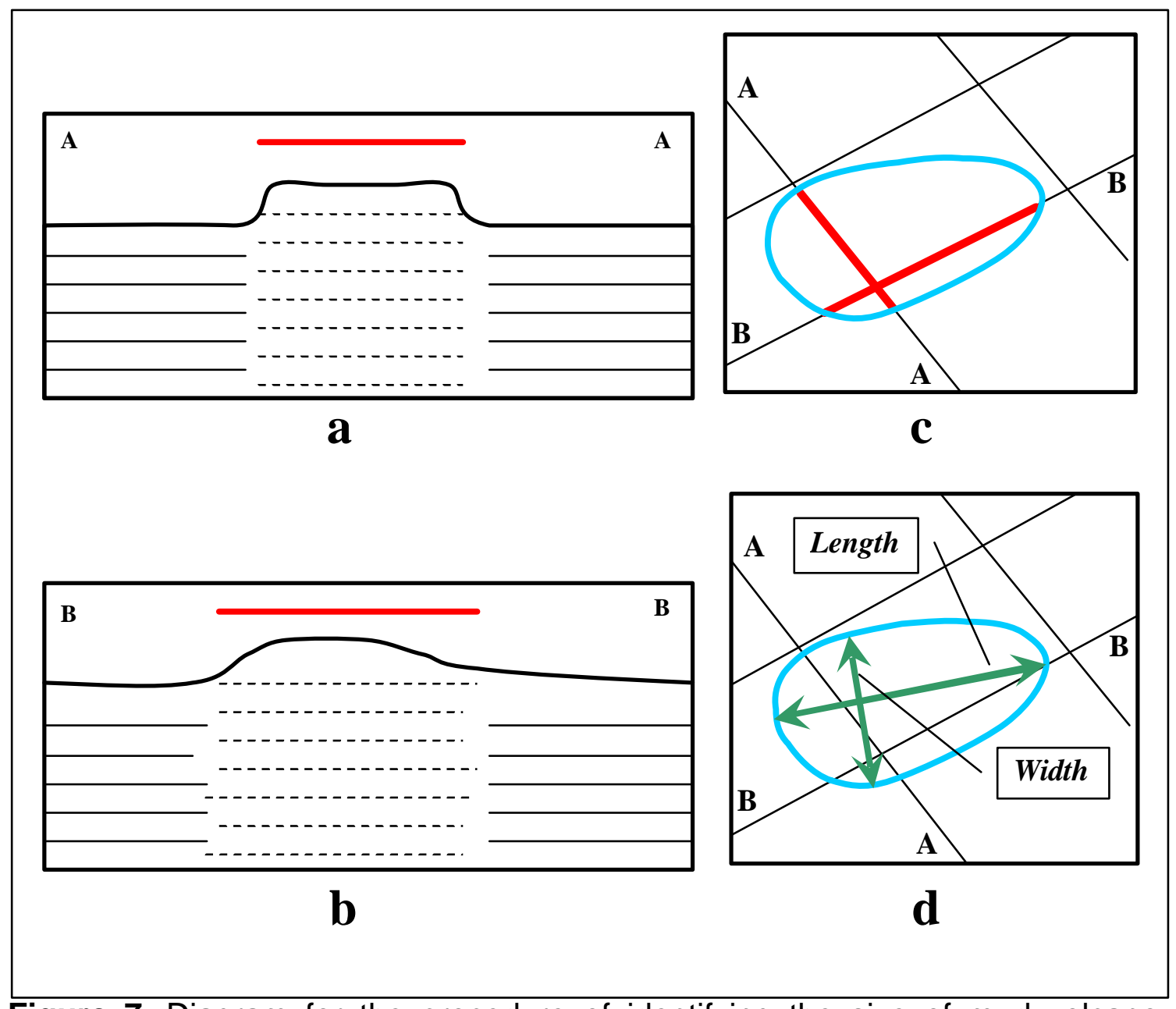

Figure 7. Diagram for the procedure of identifying the size of mud volcano. a) schematic seismic line A-A with the characteristic feature of a mud volcano. Dashed lines represent lack of a reflection underneath this feature. Red line above is the hypothetical horizon that marks an extend of the mud volcano's body. b) schematic seismic line BB that lies in the vicinity and includes the traces of observed mud volcano. c) planar view of a seismic grid with the lines A-A and B-B on it. Red lines are marked extent of the mud volcano. Blue outline is a possible area that is covered by mud volcano assuming that its body usually has a semicircular shape. d) Length and Width delineation based on the outline areal extent of the mud volcano. 
line (Figure 7a). The same procedure is applied to all other lines that intersect, or are in the vicinity of the first seismic line, until there are no other visible traces of the analyzed mud volcano (Figure 7b).

In the next stage of the analyses, the planar view of the seismic grid is employed in order to determine the size and areal extent of the mud volcano. When the horizon that is assigned to the mud volcano is retrieved, the outline of the interpreted feature is given on the base map. By connecting the contours of the marked horizons, the areal extent of the mud volcano could be defined, assuming that this feature has semicircular shape (Figure 7c). A probable area occupied by the mud volcano is then found using the planimeter option. The length of the mud volcano is assumed to be the longest distance within the outlined region. The width is the line perpendicular to the length and it captures the widest part of the outline (Figure 7d).

The height of mud volcanoes above the sea floor was determined from the following equation:

$$
H=1485 m / \sec \frac{\left(\chi_{1 m s}-\chi_{2 m s}\right)}{2000}
$$

where: $1485 \mathrm{~m} / \mathrm{sec}$ is the speed of sound wave through water; $\chi_{1 m s}$ is the two way travel time of the sea floor by the vicinity of mud volcano in milli seconds; $\chi_{2 m s}$ stands for the two way travel time of the highest point of the mud volcano in milli seconds and 2000 represents the conversion factor obtained by converting units in milli seconds to the seconds and two way travel time into one way travel time (Figure 8). In cases where 
several lines cross the body of one mud volcano, the line that shows the highest relief is chosen for height extraction.

\section{Shape of the Mud Volcanoes}

Mud volcanoes on the seismic lines have different shapes and forms. Some form a distinguished feature on the sea floor, whereas others merge into the surrounding relief and form pools of unconsolidated gassy mud. Four types of mud volcanoes that are distinguished based on their shape and appearance on the sea floor are described here: Concave, Convex, Flat and Buried.

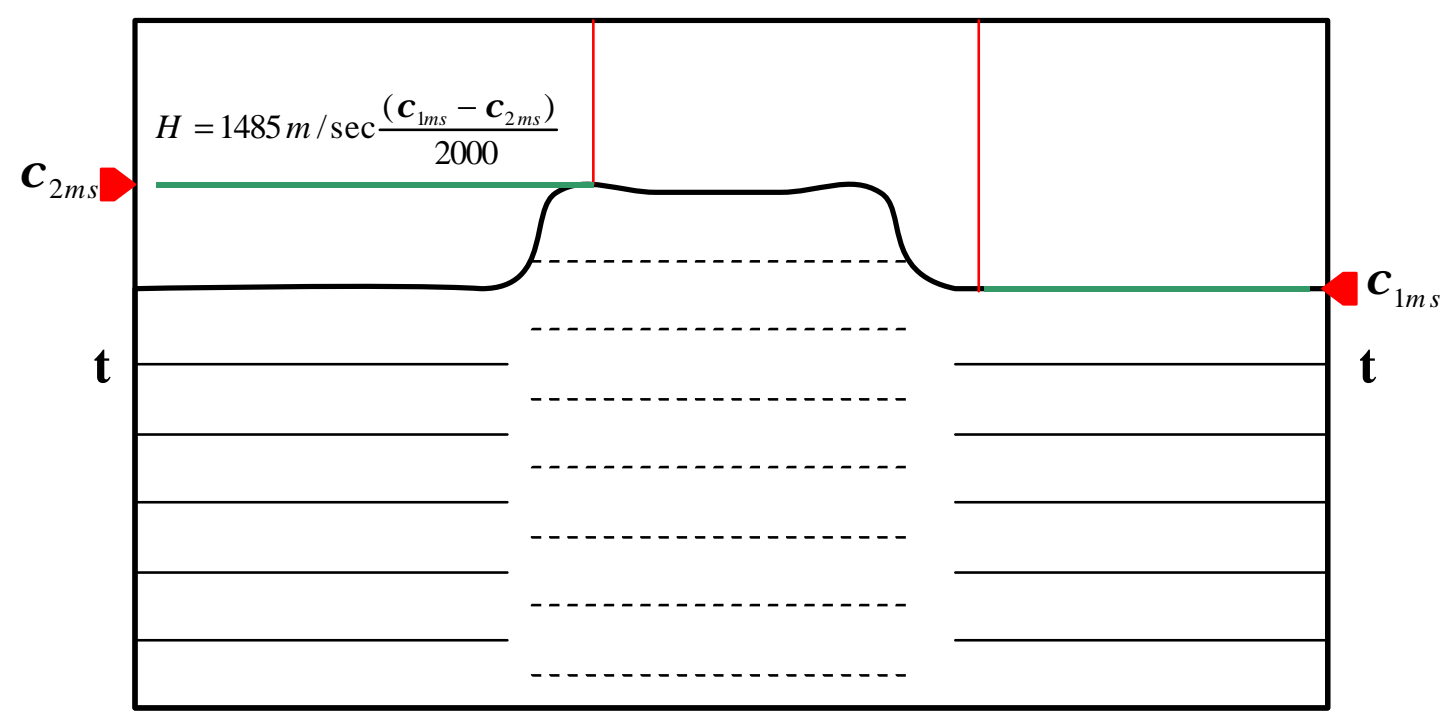

Figure 8. Diagram showing height extraction from the seismic data.

$1485 \mathrm{~m} / \mathrm{sec}$ - speed of sound wave through water; X1ms - two way travel time of the sea floor by the vicinity of mud volcano; X2ms - two way travel time of the highest point of the mud volcano; 2000 - conversion factor obtained by converting units in milli seconds to the seconds and two way travel time into one way travel time. 
Concave. This type of mud volcanoes usually has conic shape with a distinctive crater or sag on top of it (Fig 9a).

Convex. Mud volcanoes of this type have relatively smooth convex surface without any visible evidence of crater or of negative distortion on the sea floor (Figure 9b).

Flat. The mud volcanoes having a conic shape and flat reflector on the top become distinguished as a "flat" type (Figure 9c). There are cases when mud volcanoes do not have the distinctive relief as mentioned above. These features merge into the surrounding plane, but have a very strong wipeout of the seismic signal beneath them. The lack of a seismic signal may be caused by the gas saturating the sediments. The source of this gas may not be necessary related to the mud volcano activity. It may be a biogenic gas that is very common in the upper portion of the sedimentary succession or it might escape from the gas caps deeper in the section through the faults or fractures. In this case even a few percent of gas incorporated into the sediments may cause complete wipeout of the entire section. Therefore, careful examination of each seismic line that borders this feature is necessary in order to define, whether it represents a mud volcano with a flow of fluidized and gassy material, or just a seismic artifact with no relevance to the mud volcanism.

Buried. This type of mud volcanoes is characterized by the hck of any surface manifestation (Figure 9d). The body of the mud volcano is covered by sediments and has no connection with the surface. Such mud volcanoes usually have sets of stacked wedge like features interpreted as paleo flows that reveal their activity in the past. 


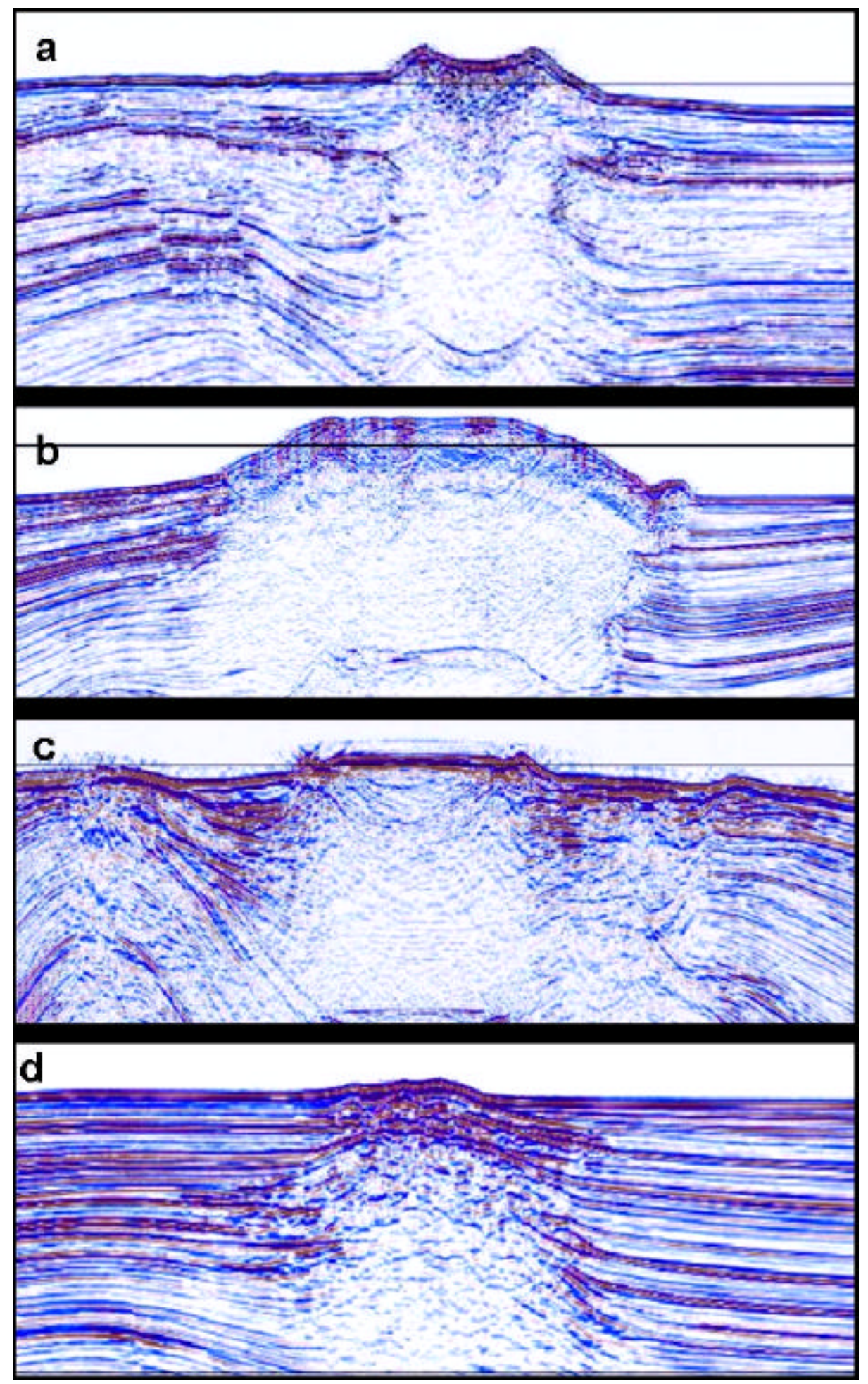

Figure 9. Types of mud volcanoes based on the shape and appearance on the seismic line. a) Concave; b) Convex; c) Flat; d) Buried. 
Even after meticulous analysis of each seismic line there is still a limitation that affects the precision of shape determination. 2D seismic coverage can not necessary provide fully accurate picture of the mud volcano. The seismic line could cross the mud volcano through the center as well as through the distant portion of its body. Depending where the seismic line crosses the mud volcano, different seismic response will become available. The same mud volcano can be interpreted as having concave shape, if the seismic line intersects its center, or convex, if the line was shot trough its side (Figure 10). Therefore certain caution should be involved when analyzing these data.

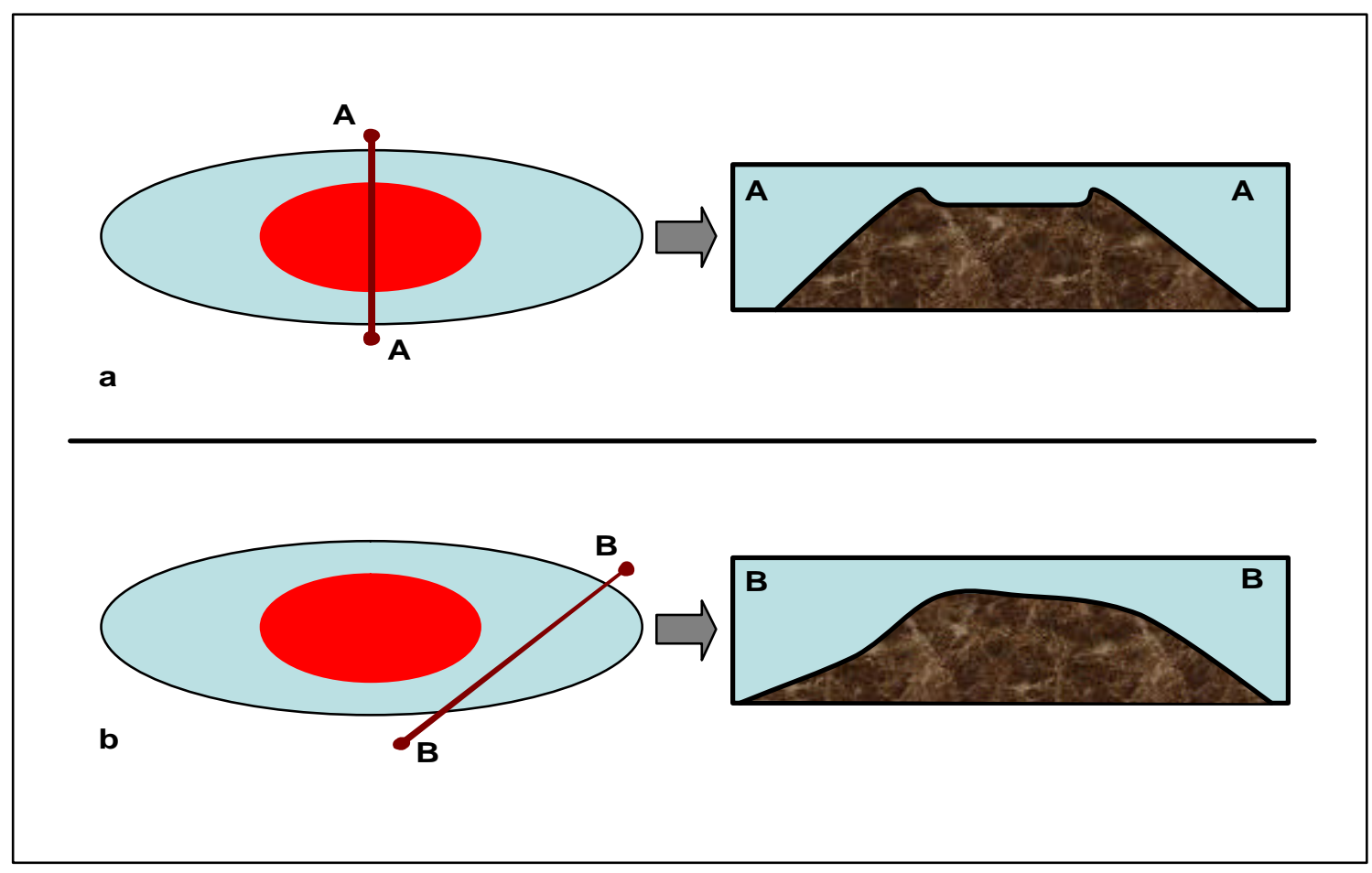

Figure 10. Change in shape of a seismic response based on the place where the line intersects the mud volcano. a) When the seismic line is shot through the center of a mud volcano; b) When the seismic line is shot through the edge of mud volcano. Note change in shape of the same mud volcano to the right. 


\section{Seismic Artifacts}

There are three seismic artifacts that were captured by this study: wipeout zone, multiples and pulldown effect (Figure 11).

Wipeout zone is a seismic artifact characterized by a lack of a seismic image through the entire or part of its section. When the seismic front reaches the gassy section, it significantly loses energy and produces a very distorted image. In this study the wipeout zone is classified according to its strength. If there is a complete lack of reflection within the observed section, the wipeout zone is classified as strong. However, if there are some but very distorted reflections present, the wipeout zone is classified as weak.

Another type of a seismic artifact that is usually associated with a mud volcano are Multiples. There are multiple reflections of the sea floor mound or of any morphological feature that could be interpreted as a mud volcano. This artifact occurs due to a big difference in seismic reflection coefficient between the highly unconsolidated, fluidized material from a given mud volcano and its surrounding rocks.

The Pulldown effect is also a common seismic artifact. As it was mentioned earlier, even a small amount of gas incorporated into the system may significantly reduce velocities of the seismic waves and thus cause artificial pulldown effect or "smile-like" features on the seismic image. This effect usually indicates shallow gas accumulations and was captured in the database.

Analysis of the seismic artifacts reveals information about the sediments that compose a mud volcano and a degree of their fluidization and gasification. In cases of a 


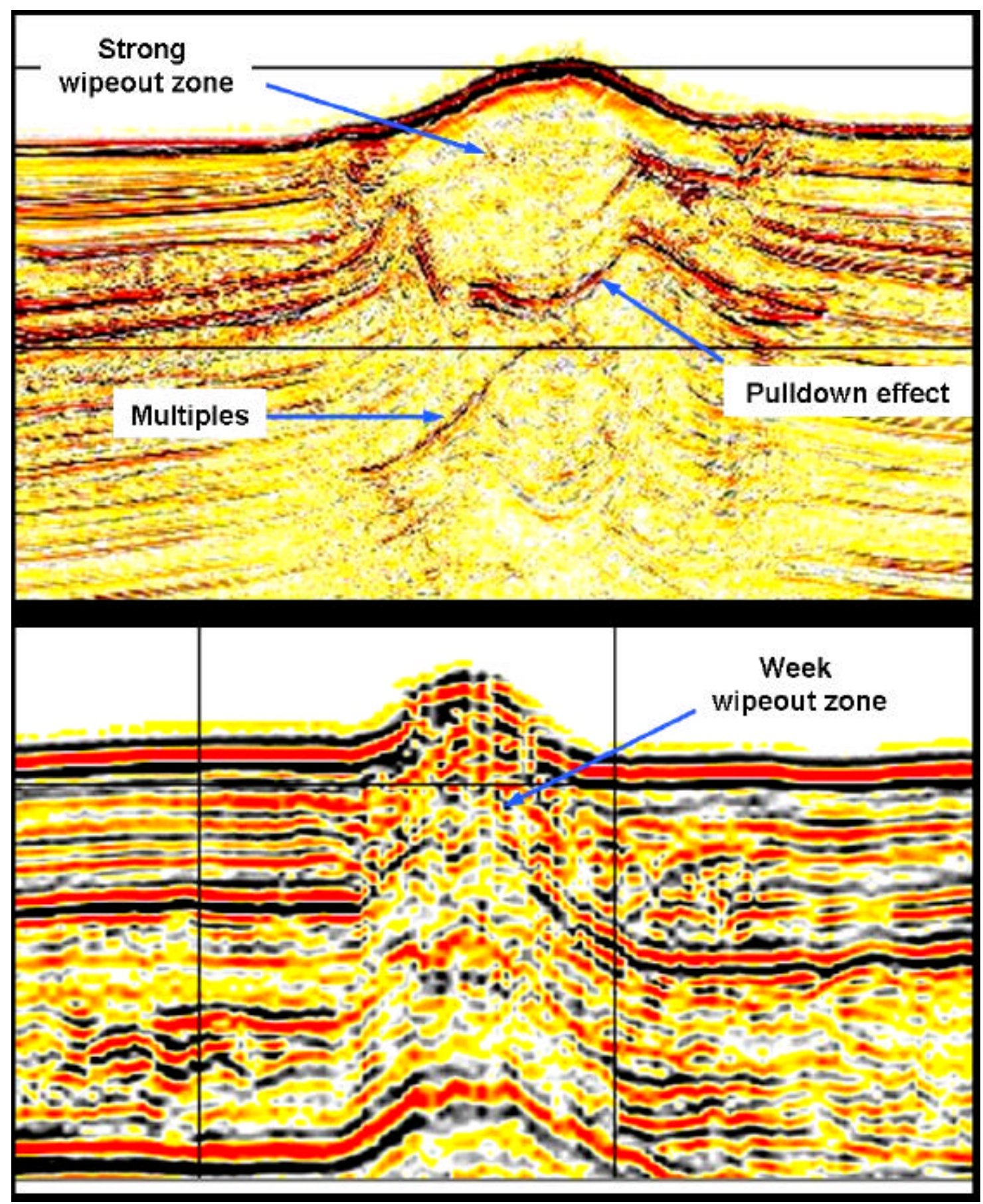

Figure 11. Examples of seismic artifacts associated with the mud volcanoes. 
strong occurrence of these artifacts the sediments may be assumed to be more fluidized by gas. This implies that the system is active and that there is a constant gas supply.

\section{Faulting and Relation to the Underlying Structure}

Each mud volcano was examined for the existence of faults in its vicinity (Figure 12). Faults play an important role in mud volcano development. They may manifest weak points of the structures and become pathways for pressure release and for the consequent eruption of the overpressured fluidized material within the mud volcano formation. Due to the importance of this particular observation, the lines that do not have traces of mud volcanoes but are situated in their vicinity were also examined to see, whether they suggested the existence of faults. In some instances, strong wipeouts distort the image and faults cannot thus be observed. In this case, information about faults may be extracted from the neighboring seismic lines or some interpretive clues from the seismic reflections around the wipeout zone.

The relationship of the mud volcano with the underlying structure is also marked, i.e. whether the mud volcano is on the top of the structure, on its side or in the syncline, it was put into the database. These data might help to understand which mechanism prevailed in the course of mud volcano formation and development. In particular what kind of pressure conditions were dominant for mud volcanism in this specific area.

\section{Collapse Structure}

Collapse structure is a peculiar feature that is associated with mud volcanoes and noted in studies of mud volcanoes in different geographic regions (Graue, 2000; 


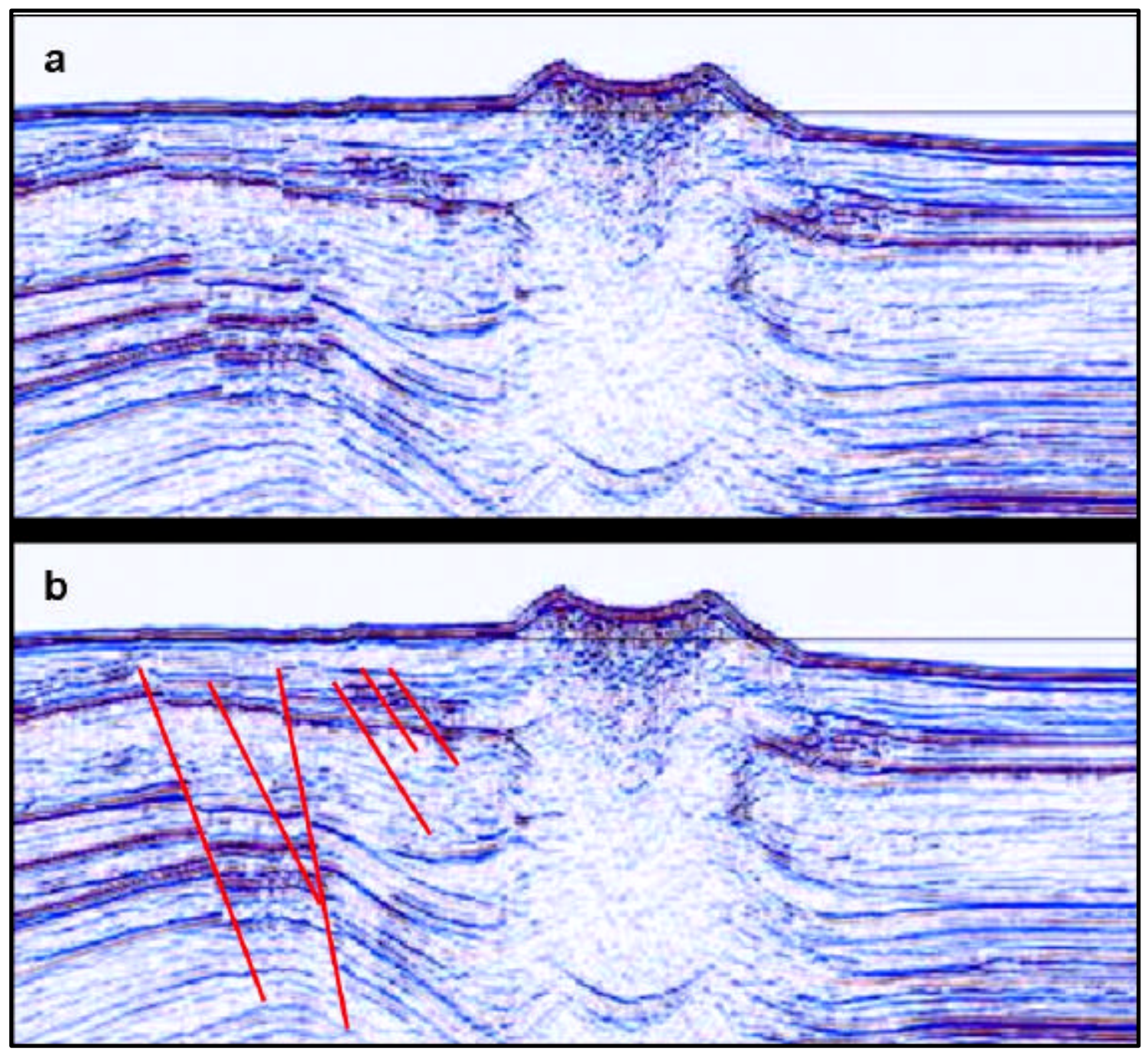

Figure 12. Example of the mud volcano with faults in the vicinity. Before (a) and after (b) interpretation. 
Kopf, 2002). This feature is the package of reflectors parallel to the overlying sediments that collapse into a zone of mass deficiency (Figure 13). Usually these structures are associated with listric faults. The base of the collapse structure may provide information about the source of mud volcano.

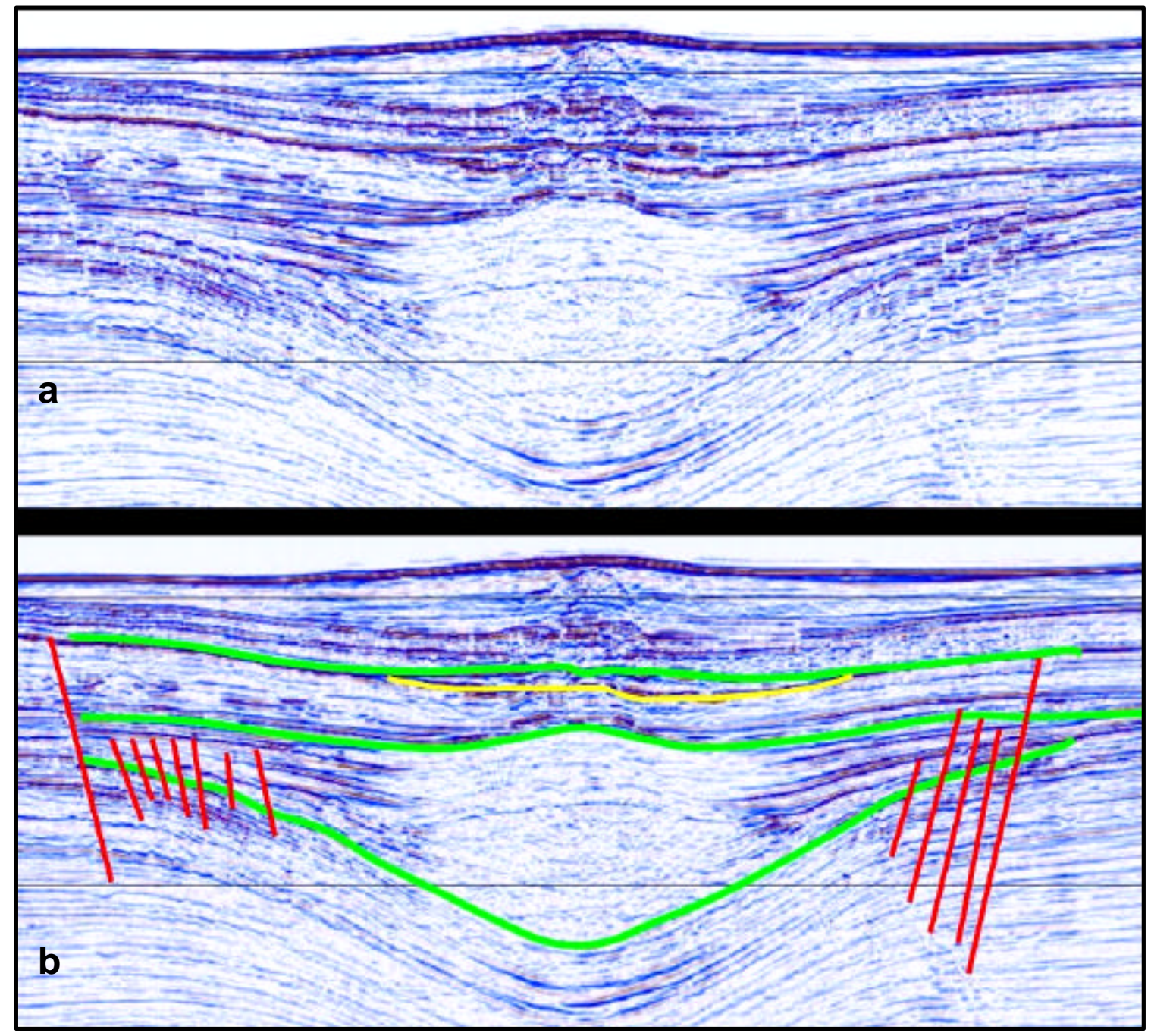

Figure 13. Example of the collapse structure before (a) and after (b) interpretation. Note faults that are product of the collapse and next generation of the mud volcano activity (yellow line), separated from the major event by the time of quiescence. 


\section{Mud Flows and Timing of Activity}

This study also reveals the presence of mud flows from the mud volcanoes and identifies the time of their activity. Mud flows that appear as a wedge like feature that encompass a disturbed reflection. They are evidence for previous stages of activity of mud volcanoes. With knowledge of the time of activity we may understand the process of development of mud volcanism within the area of study.

In order to relate the flows to the actual time intervals, previously mapped seismic horizons were used. Core and log analysis from the different wells allowed assigning relative time to these mapped reflectors. These reflectors represent the base of Sabunchi - Upper Surakhany time (4.33 MY), Uppermost Surakhany (3.5 MY), Lower Akchagyl (3.4 MY), Middle Akchagyl (2.8 MY), Upper Akchagyl (2.3 MY), Lower Apsheron (1.8 MY), Upper Apsheron (1.3 MY), Lower Quaternary (0.75 MY), Middle Quaternary (0.63 MY), Upper Quaternary (0.3 MY). A simple procedure is followed in order to relate the paleo flows to the relative time intervals (Figure 14). First all lines that define the studied mud volcano are inspected in order to determine the existence of paleo flows. Once these features are outlined, their relevance to the particular time interval is defined. If the mud flow occurs between the mapped horizons, the time of the lower horizon is assigned to it. The data capturing the timing of the mud flows are incorporated into the database in the following manner:

a) The time of certain activity - the time intervals when flow is clearly visible and easily distinguished. 


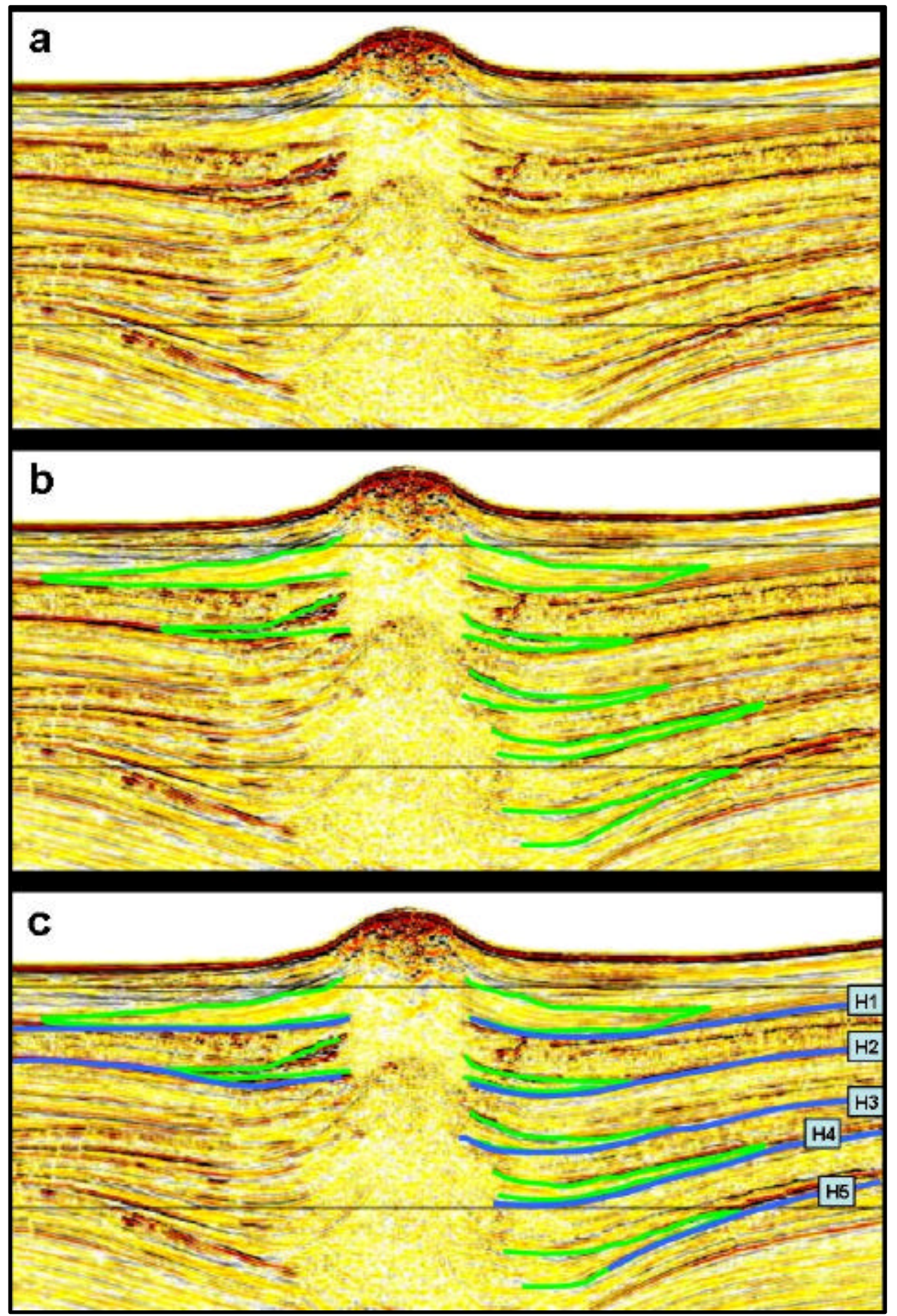

Figure 14. Scheme for identifying time of mud flows. a) Seismic line without interpretation; b) Same seismic line with identified mud flow features and c) mapped reflectors. The time of the first from the top flow is $\mathrm{H} 1$ time, second is $\mathrm{H} 2$ time and etc. 
b) The time of probable activity - the time intervals when flow is difficult to recognize because of low resolution of the seismic data, decreasing quality of the seismic data with depth or due to other seismic artifacts that distort the image. In this case, there are assumptions made when revealing the evidence of paleo activity.

c) The time of no activity - the time intervals when there is no visible evidence of mud flows. However, there are instances when the seismic lines are disturbed by the wipeout zones and there is no opportunity to determine paleo activity. If none of the bordering seismic lines reveal the evidence of flow then this particular mud volcano is assumed to have no past activity. In addition, the presence of large and shallow "mud chambers", their tendency to enlarge themselves, the ability of mud to be injected to the subsurface zones of weakness and consequently form highly irregular shapes substantially complicate precise dating of the mud volcano activity (Cooper, 2001).

\section{Observations and Database Analysis}

Here the analysis of data described above is presented in order to show the major trends in their distribution. The interpretation of the observations will be discussed in the next chapter.

The analysis of the seismic lines reveals 99 mud volcanoes within the area of study. The map presented in Figure 15 shows the position and areal extent of each mud 


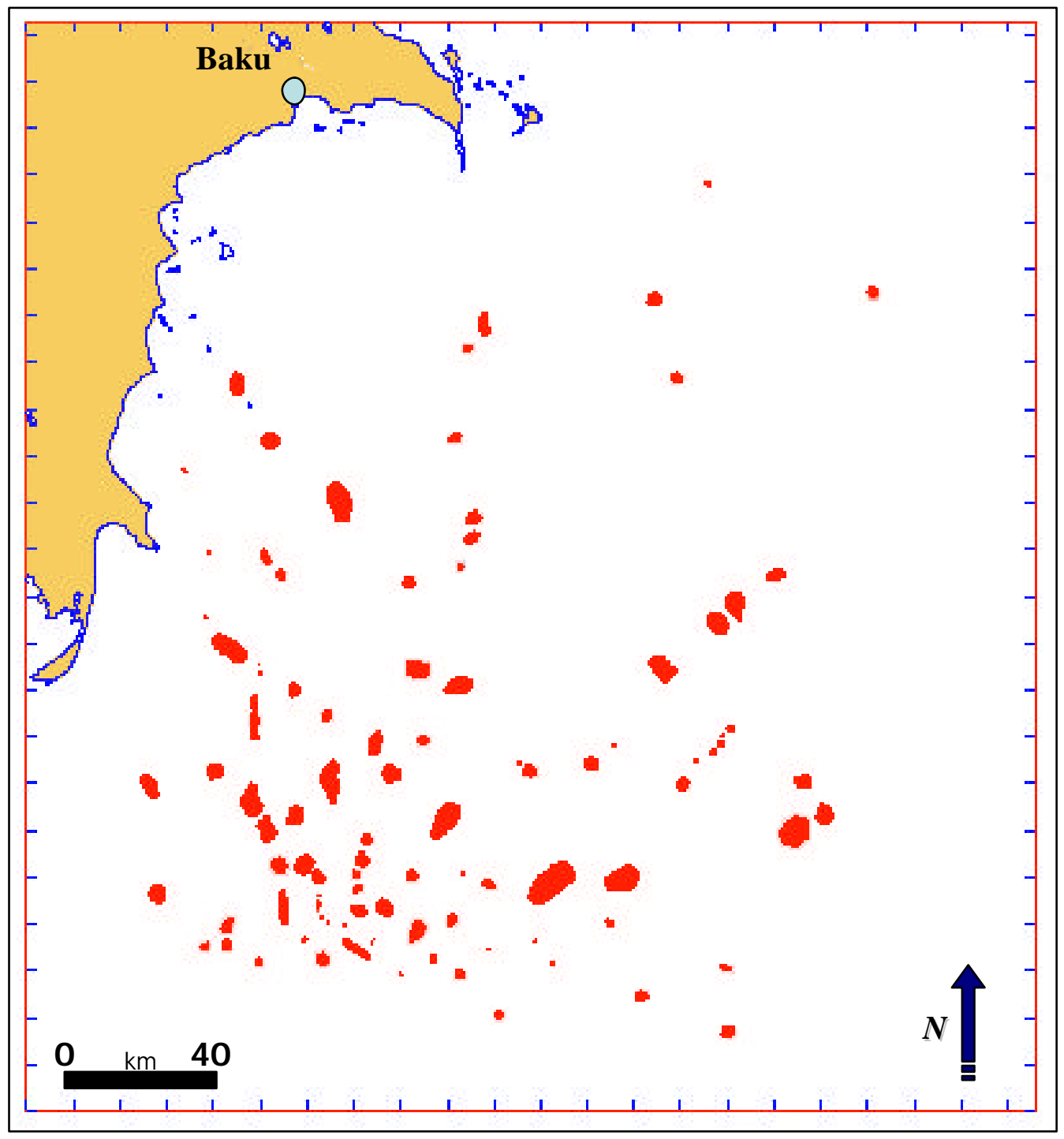

Figure 15. Areal distribution of the mud volcanoes within the area of study.

volcano included in the database. There is a large concentration of mud volcanoes in the southern part of the examined area coinciding with the distribution of the subsurface structures. Towards the north and northeast, the morphological features on the sea floor become less dense. The mud volcanoes here tend to be larger in area. The major limitation in creating this map was the $2 \mathrm{D}$ seismic grid. Areas where seismic grid is 
coarse (Figure 1) should be considered less reliable in comparison with the ones of a finer grid. However, even though the spacing between the lines range between 5 to $5 \mathrm{~km}$ and 2.5 to $2.5 \mathrm{~km}$, it is necessary to analyze the data with a certain degree of caution. Studies on mud volcanoes onshore as well as numerous 3D surface extractions of the sea floor around mud volcanoes (Guliyev and Feyzullayev, 1995; Graue, 2000; Dimitrov, 2002; Fowler et al., 2000) show that the body of a mud volcano may consist of many morphological features (gryphones, salsas, domes). These elements can occur on the volcanic plateau itself or can be attached to it within some proximity. Therefore, the feature that is interpreted as a separate mud volcano might be a part of one volcanic system. The 2D seismic coverage is too coarse to distinguish between these relatively small features.

The height and areal extent of the mud volcano are the most important values among those that describe an actual size of the feature. Studies of onshore mud volcanoes in Azerbaijan revealed a relationship between these two parameters (Guliyev and Feyzullayev, 1995). According to Azeri scientists, the height and areal extent of a mud volcano depends on the physical properties of the material that had been erupted.

Lerche and Bagirov (1999) describes different variables of mud volcanoes (length, width, area, and diameter) observed onshore Azerbaijan. He derives equations showing the relationships between these variables for the onshore data. Offshore data from this study when applied to his equations give significant different results. Lerche and Bagirov (1999) notes that mud volcano flow is different on land surfaces than on the sea floor. In offshore conditions, turbidity flows associated with the mud volume release 

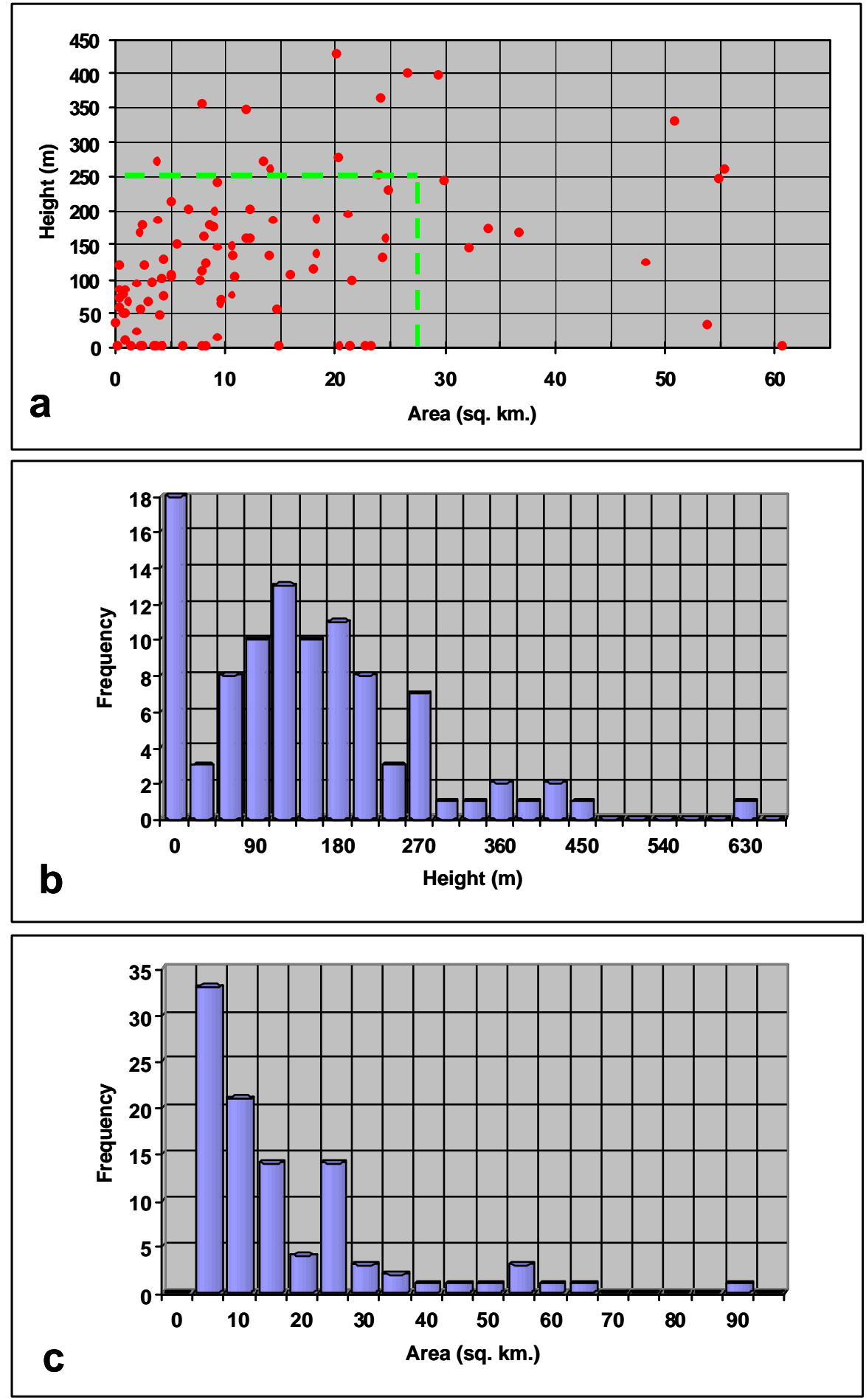

Figure 16. a) Plot of the area versus height of the mud volcanoes; b) height and c) area distribution from the obtained data population. 
may decrease the length of the mud flow. The low viscosity of mud flows in marine conditions compared with those on land would make the distance covered by a marine mud flow greater. However, the areal extension of the mud volcanoes both onshore and offshore depends on the local morphology and on the angle of the slope.

Simple statistical analysis of the height and areal extent of mud volcanoes (Figure $16 \mathrm{~b}, \mathrm{c}$ ) shows exponential distribution of these data sets. Probability plots constructed to confirm this observation also show a non-linear pattern within these values. About $80 \%$ of all mud volcanoes do not exceed 240-270 meters in height and 25 square kilometers in areal extent (Figure 16a). There are instances of mud volcanoes with great areal extent and very low relief as well as of small mud volcanoes with significant elevation. The map of the relative height of the mud volcanoes within the area of study illustrates the concentration of the mud volcanoes with steep slopes and with small areal extent in the south-west and of those with low relief and with great areal extent in the north-east (Figure 17).

Most of the analyzed mud volcanoes create convex and flat shaped features on the seafloor (Figure 18b). About $46 \%$ and $33 \%$ of them respectively compose this major group of mud volcanoes. Others form concave and buried types - $11 \%$ and $10 \%$ respectively. There is no apparent regularity in distribution of these different types of mud volcanoes (Figure 18a). They are scattered mainly chaotically without visible trends. However, a tendency in the concentration of convex and buried mud volcanoes can be noticed in the south, whereas towards north and north-east there is a tendency for concave and flat features. 


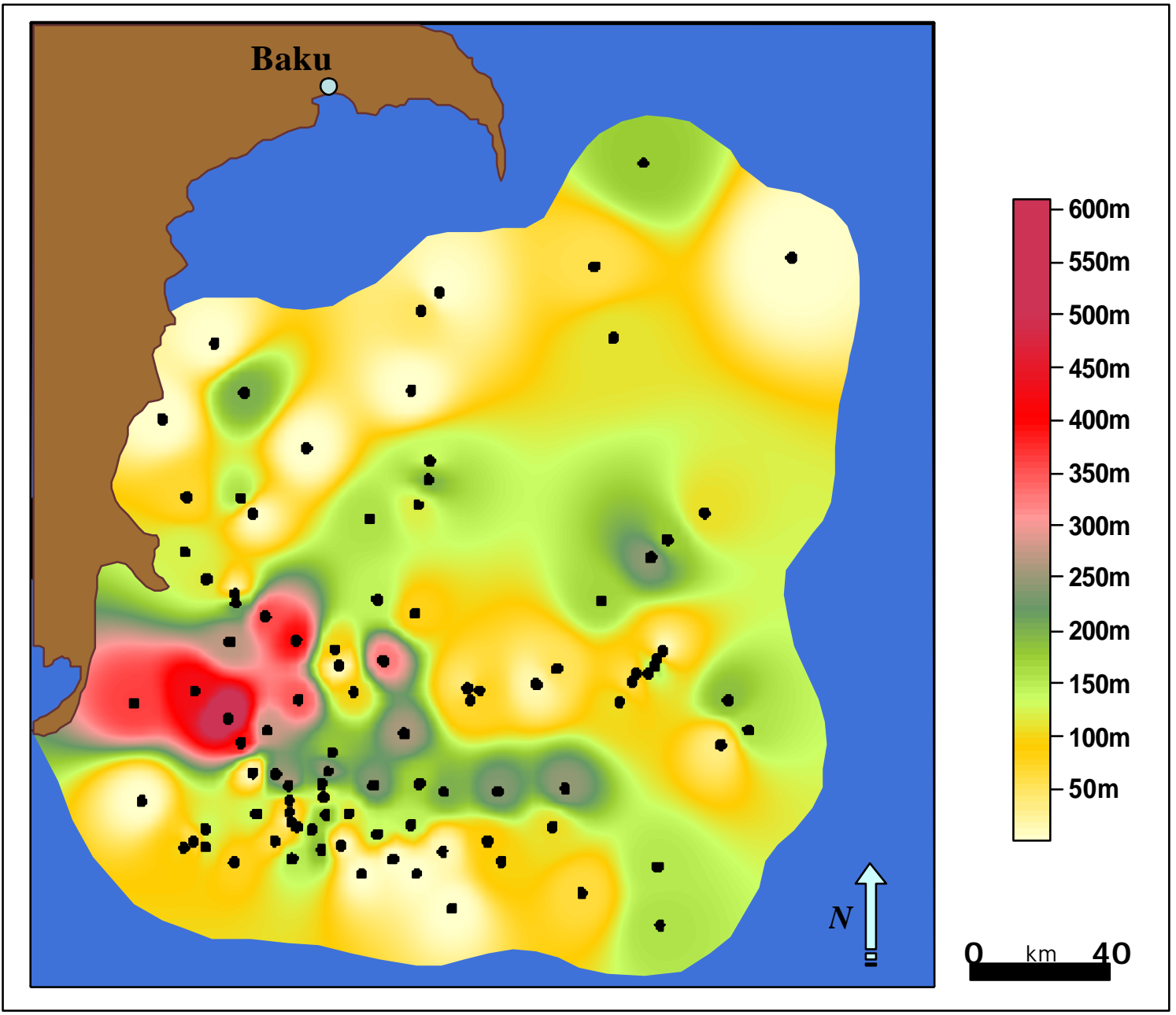

Figure 17. Relative height of the mud volcanoes.

Analysis of the captured seismic artifacts shows 42 out of 99 mud volcanoes with a strong wipeout zone, 49 of them have multiples and only 18 have visible pulldown effect.

Most of the mud volcanoes are situated above the anticlines that are complicated by faults. Examination of the data sets obtained from the seismic shows that $74 \%$ of all mud volcanoes develop on the crest of the subsurface structures (Figure 19b). Moreover, 


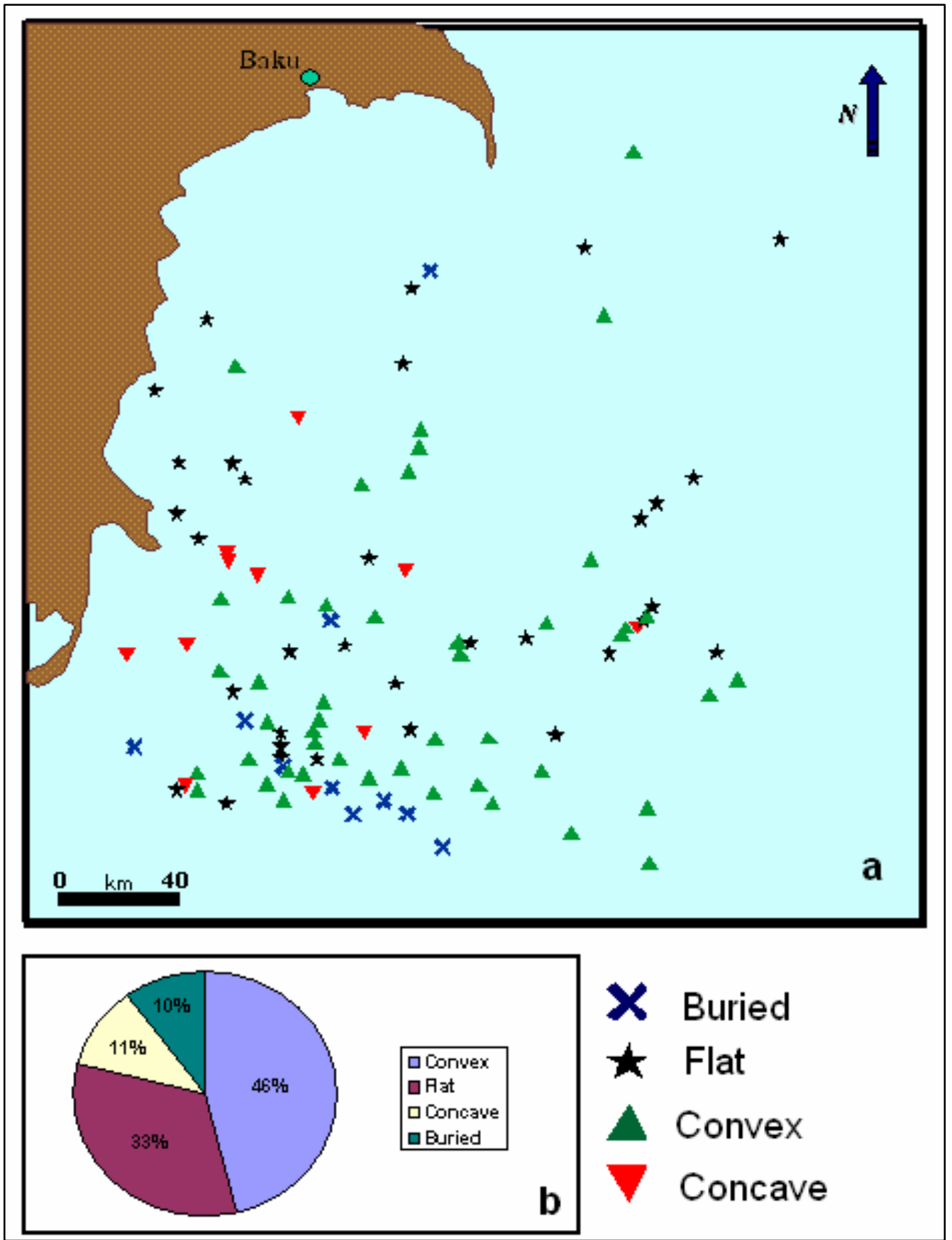

Figure 18. a) Areal distribution of the mud volcanoes of different shapes; b) pie diagram reflecting distribution of the mud volcanoes with the specific shape. 

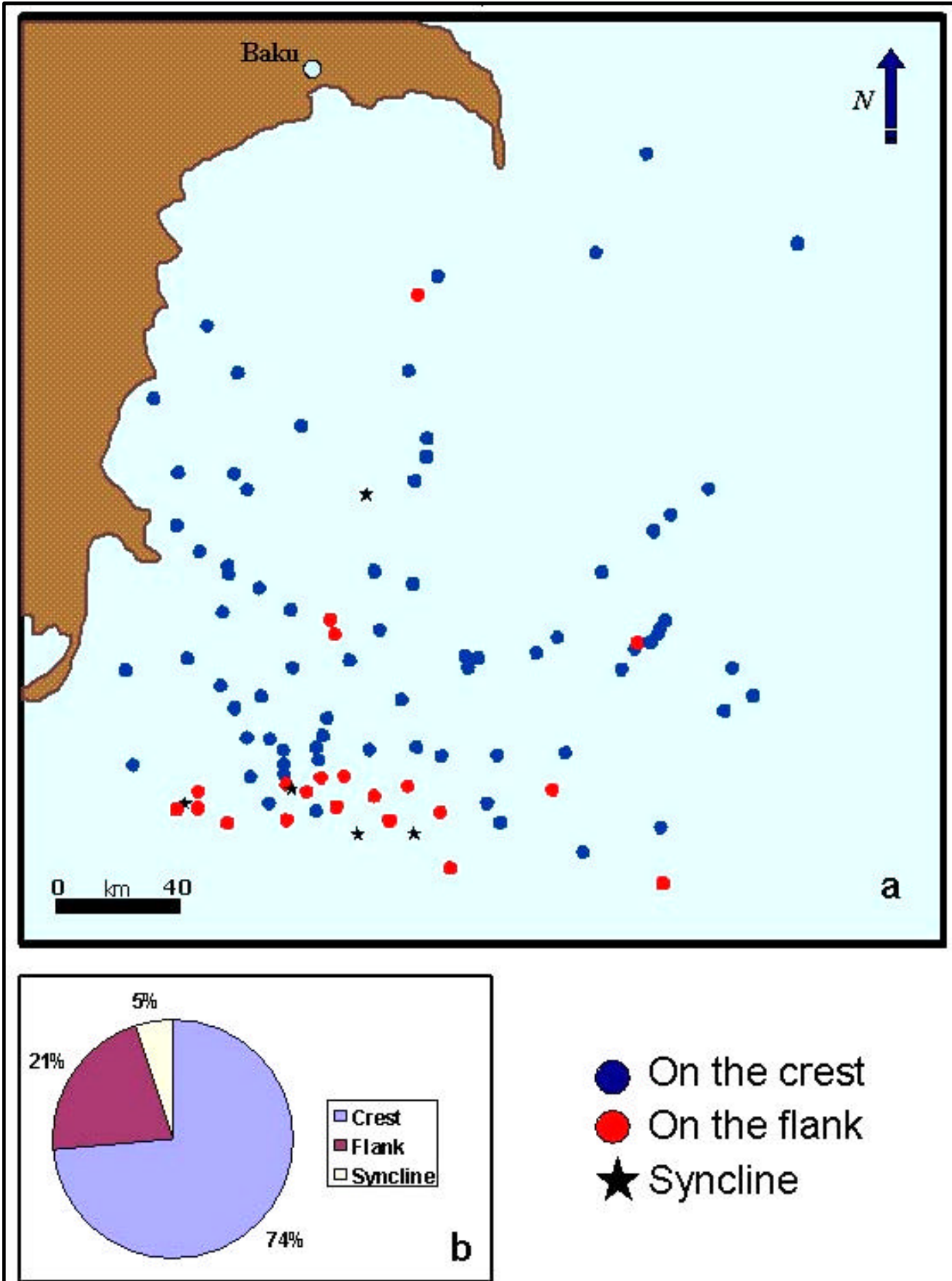

On the crest

On the flank

$\star$ Syncline

Figure 19. a) Position of the mud volcanoes relative to subsurface structure; b) pie diagram reflecting distribution of the mud volcanoes relative to the subsurface structure. 
there are 21 mud volcanoes that form on the flanks. Analysis of the database for an existence of distinctive collapse structures reveal 35 mud volcanoes associated with them. Syncline mud volcanoes are of a great interest to scholars. Their mechanism of formation is still not very well understood. It is possible that these features represent evidence of a large pressure breakthrough that developed under very active tectonic conditions. There are 5 mud volcanoes that formed in the synclines within the area of study. Most of the mud volcanoes that are situated above the flanks of the subsurface structures are concentrated in the south (Figure 19a). Similar pattern follows distribution of syncline mud volcanoes. However there is one case when a syncline mud volcano occurs on the north between two big structures and will be discussed further in the next chapter.

Analysis of paleo flows reveal cyclicity in mud volcano development. Figure 20 represents mud volcano activity through time captured in a cumulative curve of activity of the analyzed mud volcanoes from lower Pliocene time through upper Pleistocene.

The oldest time of activity within the area of study corresponds to the SurakhanySabunchi time (4.33 MY). In this study, this period is considered as the beginning of the mud volcano activity in the offshore South Caspian Basin. As shown in the activity chart, there are several cycles of mud volcano development. Each cycle consists of the period of increasing activity, of the period of stable activity and of the period of general quiescence followed by the beginning of the next cycle. In order to observe the evolution of mud volcano development in offshore Azerbaijan, a series of maps that reveal the activity in different time periods are created. These are intensity maps that 


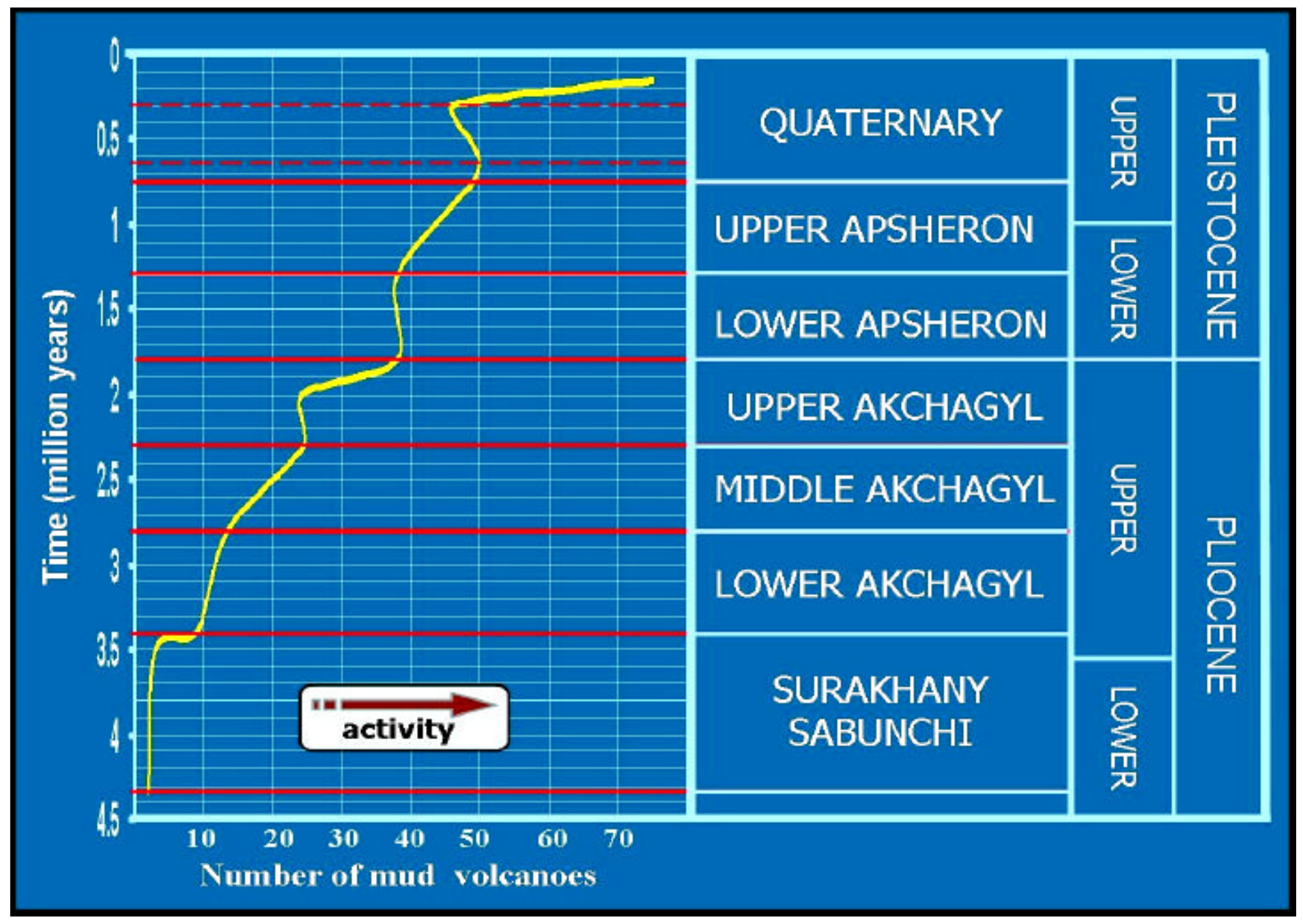

Figure 20. Mud volcano activity through time. See text for details. 
show the areas of definite and possible activity as well as areas where no activity was discovered (see Figures 21a-21f). The following discussion concentrates on the intervals of the greatest mud volcano activity.

During Sabunchi-Surakhany time (4.33 MY) mud volcano development initiated. There is only one mud volcano that has certain activity within this region. It should be pointed out that this volcano developed in the syncline zone. Two other locations, one in the south and another one in the north, may have also been active during this period of time.

Uppermost Surakhany time (3.5 MY) has a similar appearance except that one of the mud volcanoes in the south became active. In this study, this time is recognized as the beginning of the first cycle of mud volcano activity within the South Caspian Basin.

By the Upper Akchagyl time (2.3 MY), the area evolves into a much intense stage. There are more volcanoes in the south that initiate their activity during this time. The central part of the area also underwent mud volcano development, while the northern part was still without evidence of mud volcano activity.

Upper Apsheron time (1.3 MY) shows the progressive spreading of the mud volcano activity from south to north. Along with many other mud volcanoes that developed during this time in the south, the northern part also substantially evolves into this stage. It is important to notice that some of the previously active mud volcanoes actually ceased development and became dormant.

Lower Quaternary time $(0.75 \mathrm{MY})$ is manifested by even further intensification of the mud volcano development process. Along with the mud volcanoes in the north 


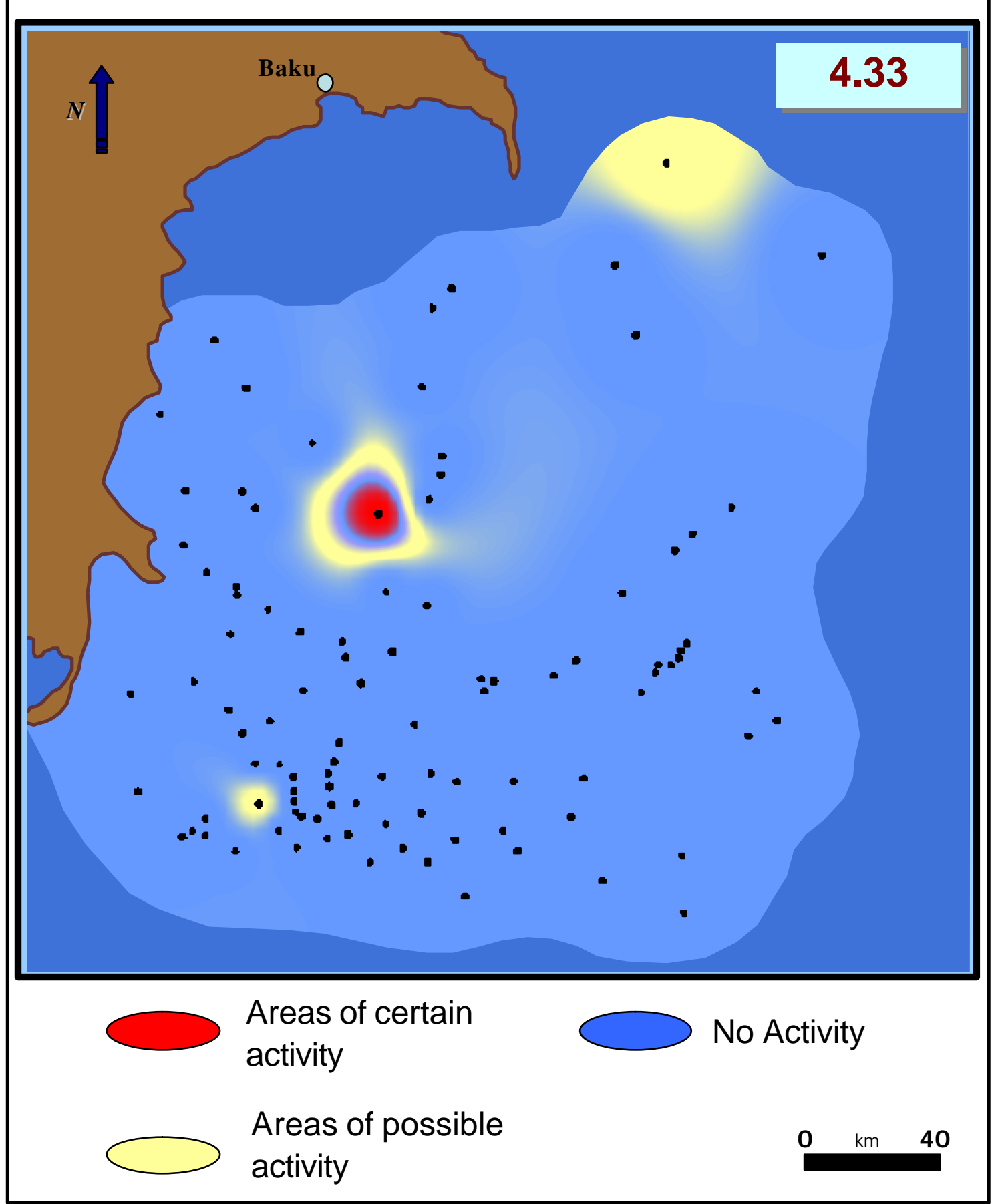

Figure 21a. Maps of mud volcano development in different periods of time: Activity in Subunchi-Upper Surakhany time (4.33 MY). 


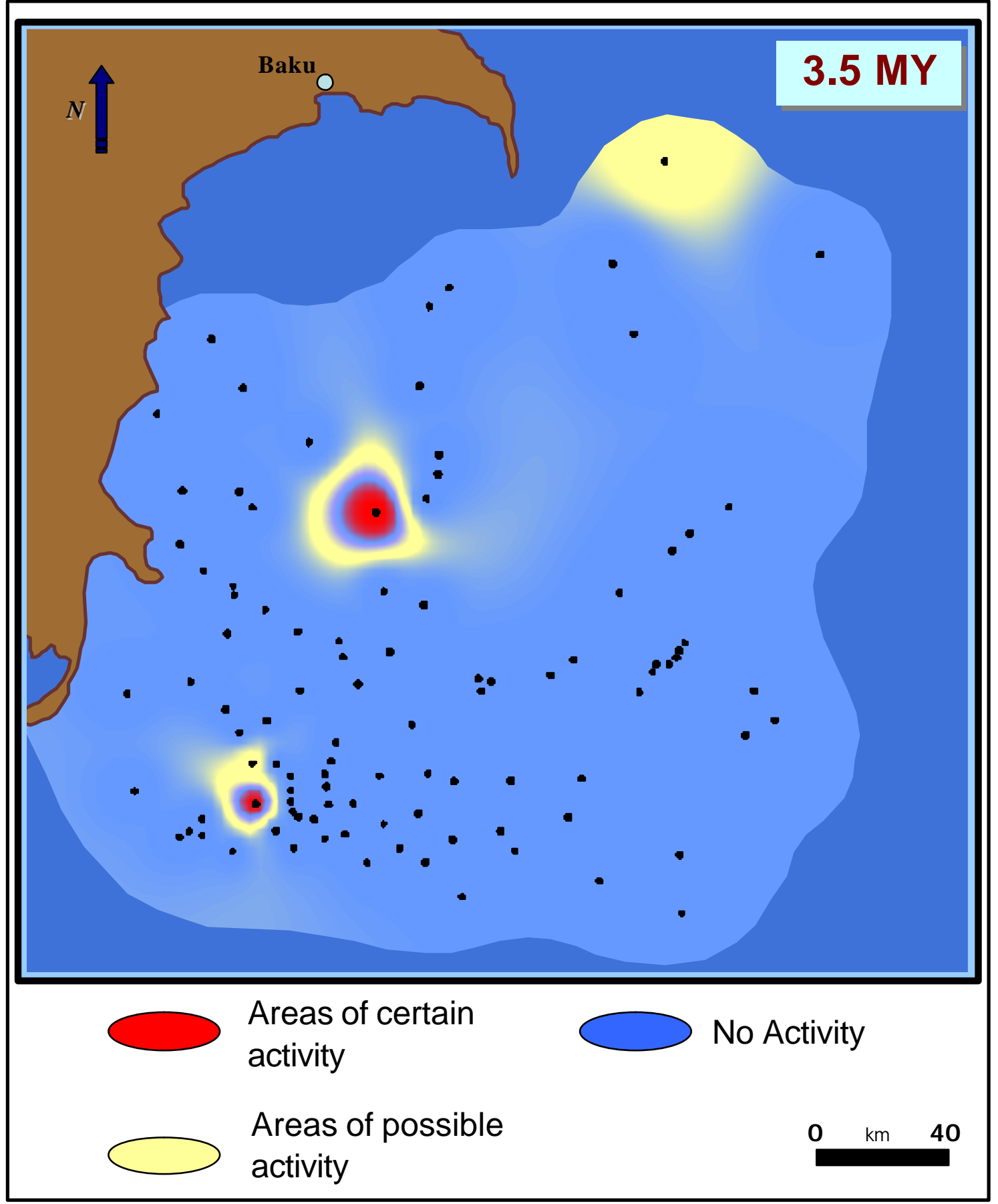

Figure 21b. Maps of mud volcano development in different periods of time: Activity in Uppermost Surakhany time (3.5 MY). 


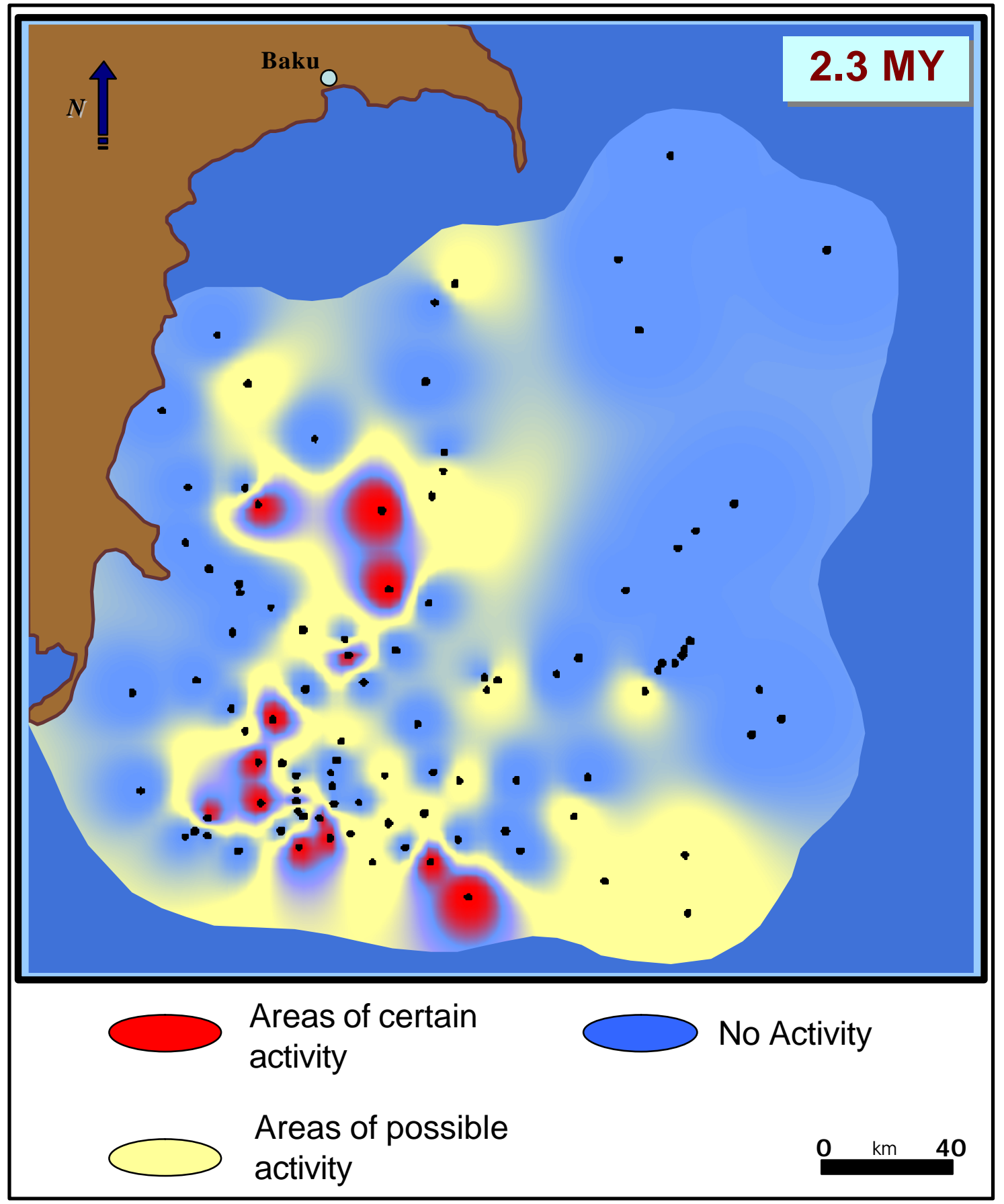

Figure 21c. Maps of mud volcano development in different periods of time: Activity in Upper Akchagyl time (2.3 MY). 


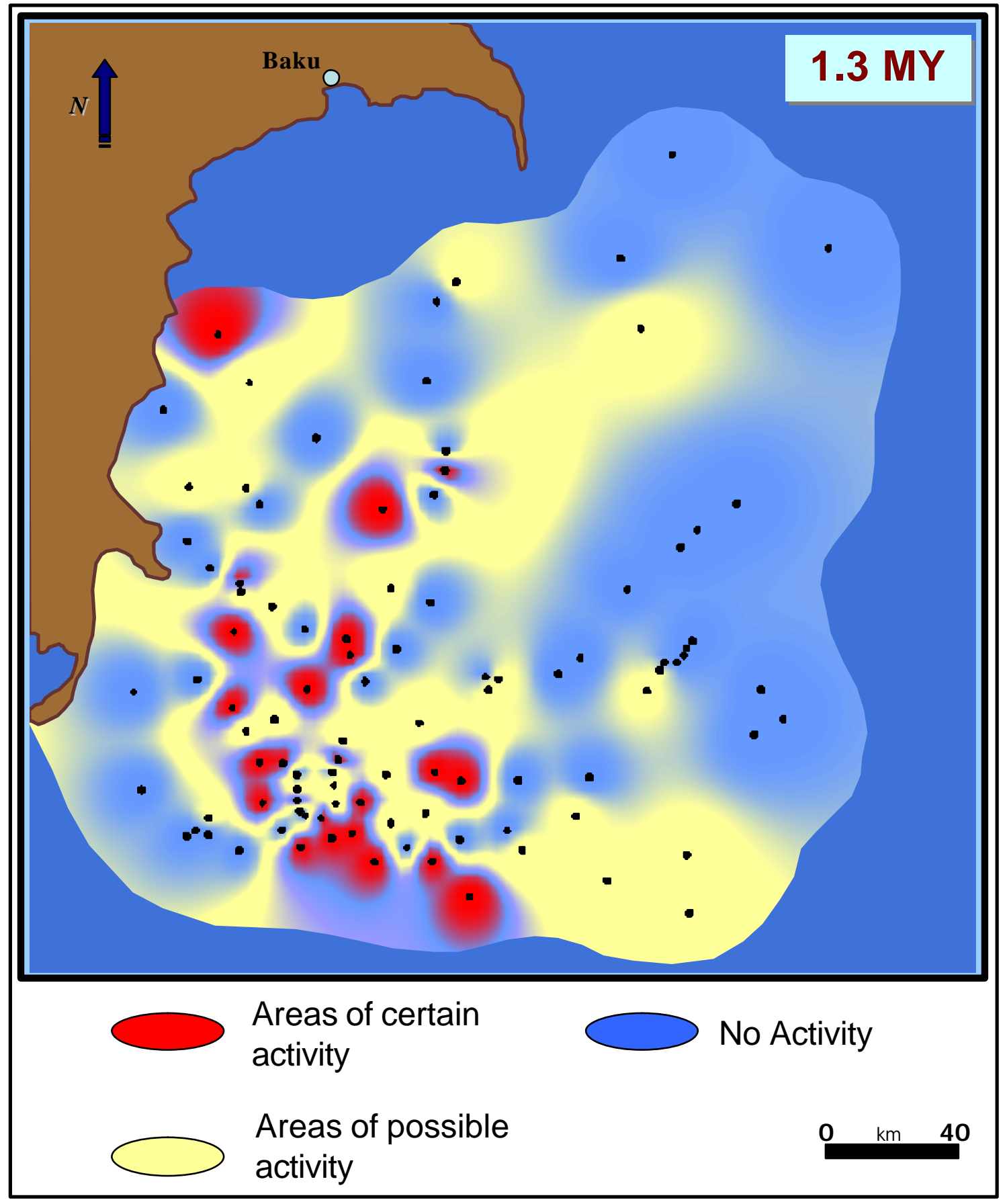

Figure 21d. Maps of mud volcano development in different periods of time: Activity in Upper Apsheron time (1.3 MY). 


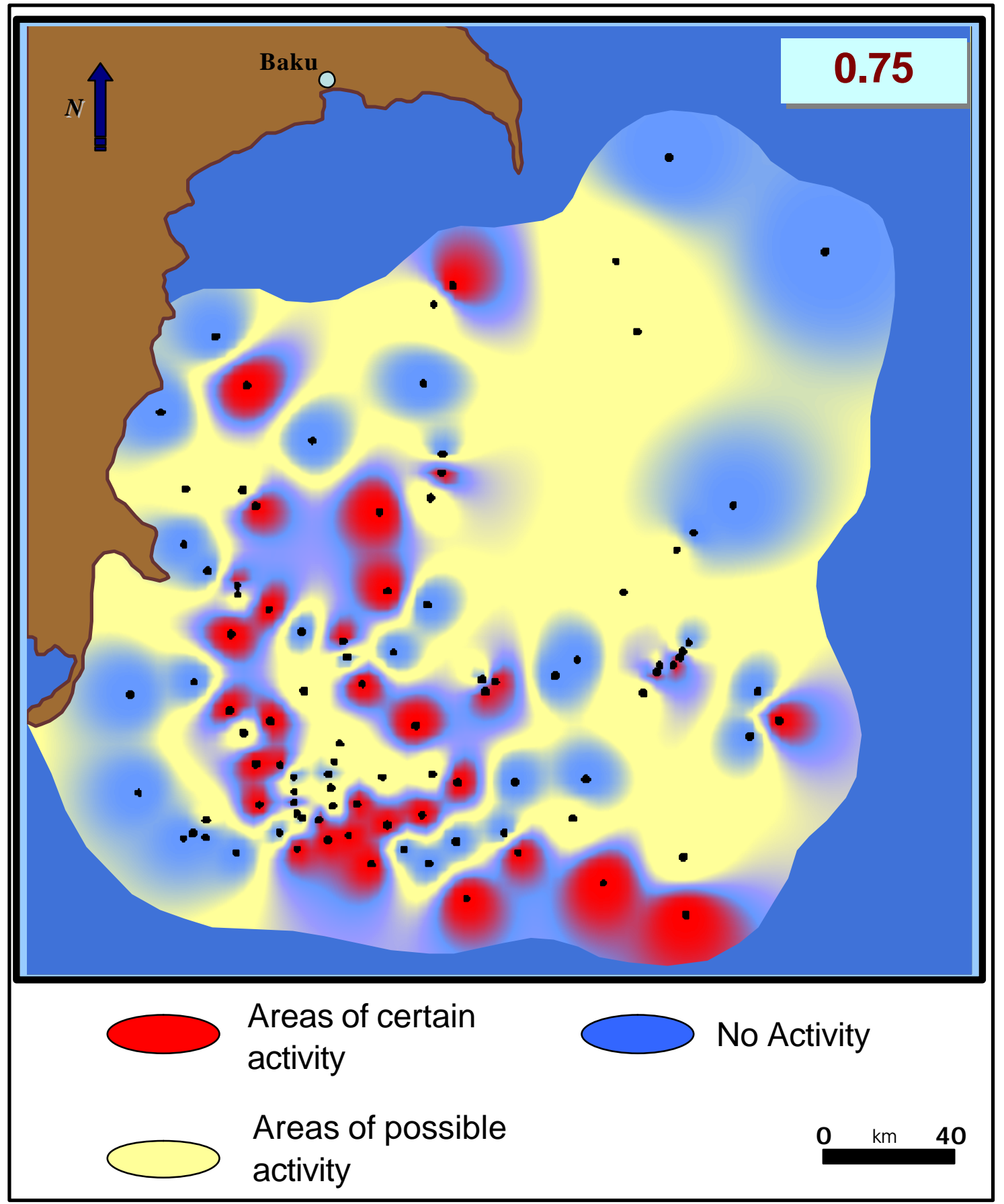

Figure 21e. Maps of mud volcano development in different periods of time: Activity in Lower Quaternary time (0.75 MY). 


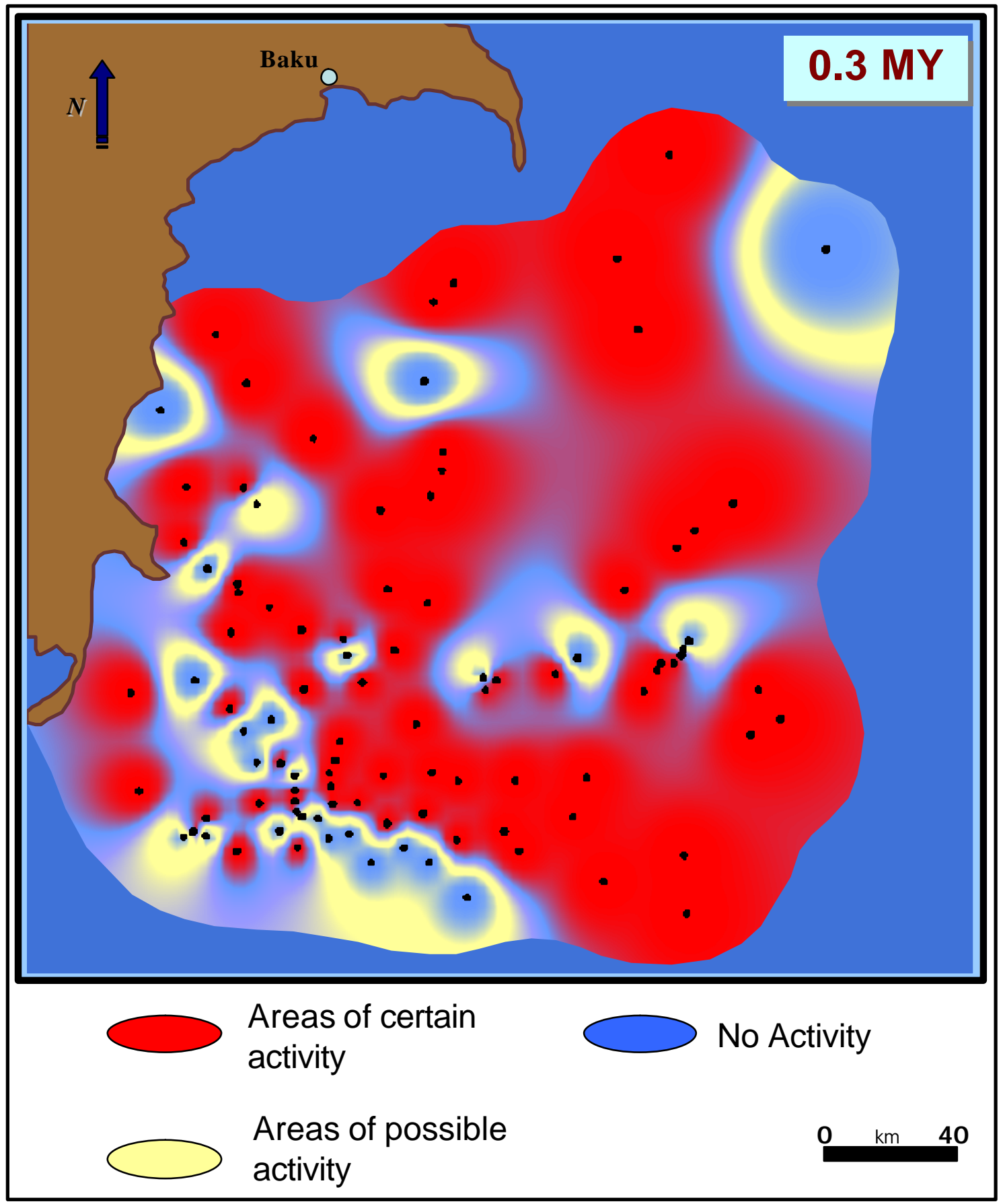

Figure 21f. Maps of mud volcano development in different periods of time: Activity in Upper Quaternary time (0.3 MY). 
and in the central part of the region, there are more volcanoes in the south that became active during this time.

Finally, by the Upper Quaternary time (0.3 MY), most of the region is involved in mud volcanic activity. However, some mud volcanoes in the south-west region, after being active since lower Akchagyl have become inactive.

In conclusion, the following summarizes the major observations that were made after extensive analysis of the database:

- 99 Mud Volcanoes have been recognized.

- Most mud volcanoes are situated above anticlines that are complicated by faults.

- Mud volcanoes that develop on the flanks of the structures are clustered in the south.

- Syncline mud volcanoes are concentrated also in the south.

- $35 \%$ of mud volcanoes have a distinctive collapse feature associated with them.

- Mud volcanoes with steep slopes and with small areal extent are mainly concentrated in the south-west.

- Mud volcanoes with low relief and with great areal extent are clustered in the north-east.

- Four types of mud volcanoes were recognized based on the shape of the morphological features on the sea floor: Concave, Convex, Flat and Buried. 
- Cyclicity in mud volcano development was revealed, with their beginning in

Lower Pliocene (Sabunchi-Surakhany time) and with the greatest activity during Upper Pleistocene (Upper Apsheron - Quaternary time).

- In general, there is a chaotic pattern in distribution of all mud volcano parameters (shape, size, etc.). 


\section{CHAPTER IV}

\section{DISCUSSION AND CONCLUSIONS}

Mud volcanism is a widespread phenomenon. It occurs in many regions that have in general similar geological settings. Figure 22 shows the geographical occurrence of mud volcanoes on Earth. They predominantly develop at convergent plate margins, where high volume of the sediments is subjected to great lateral and vertical stresses. The actual number of features, as well as the amount of material involved in mud volcanism, is much greater in offshore areas than onshore.

Mud volcanoes in collisional settings show many similarities in geometry, age, material extruded, and volatile emission. The region where most of the mud extrusions have been found is in the Mediterranean Sea and Tethyan Belt, stretching from south of Greece over the Black and Caspian Seas into Azerbaijan, the Crimea and Taman Peninsulas, Iran, and Turkmenistan into the Makran coast. Azerbaijan is the region of the world's densest onshore and offshore population of mud volcanoes and is an excellent area to study this phenomenon. First, they have been described in the works of many scholars (Kulschin, 1845; Abich, 1863; Jakubov et al., 1971; Guliyev and Feyzullayev, 1995; Lerche and Bagirov, 1999) and second, the mud volcanoes in this region represent a collection of features with different forms and sizes from onshore to marine settings.

Extensive studies of onshore mud volcanoes in Azerbaijan concluded that mud volcanism in this area is a manifestation of mud diapiric processes. The theory proposed 


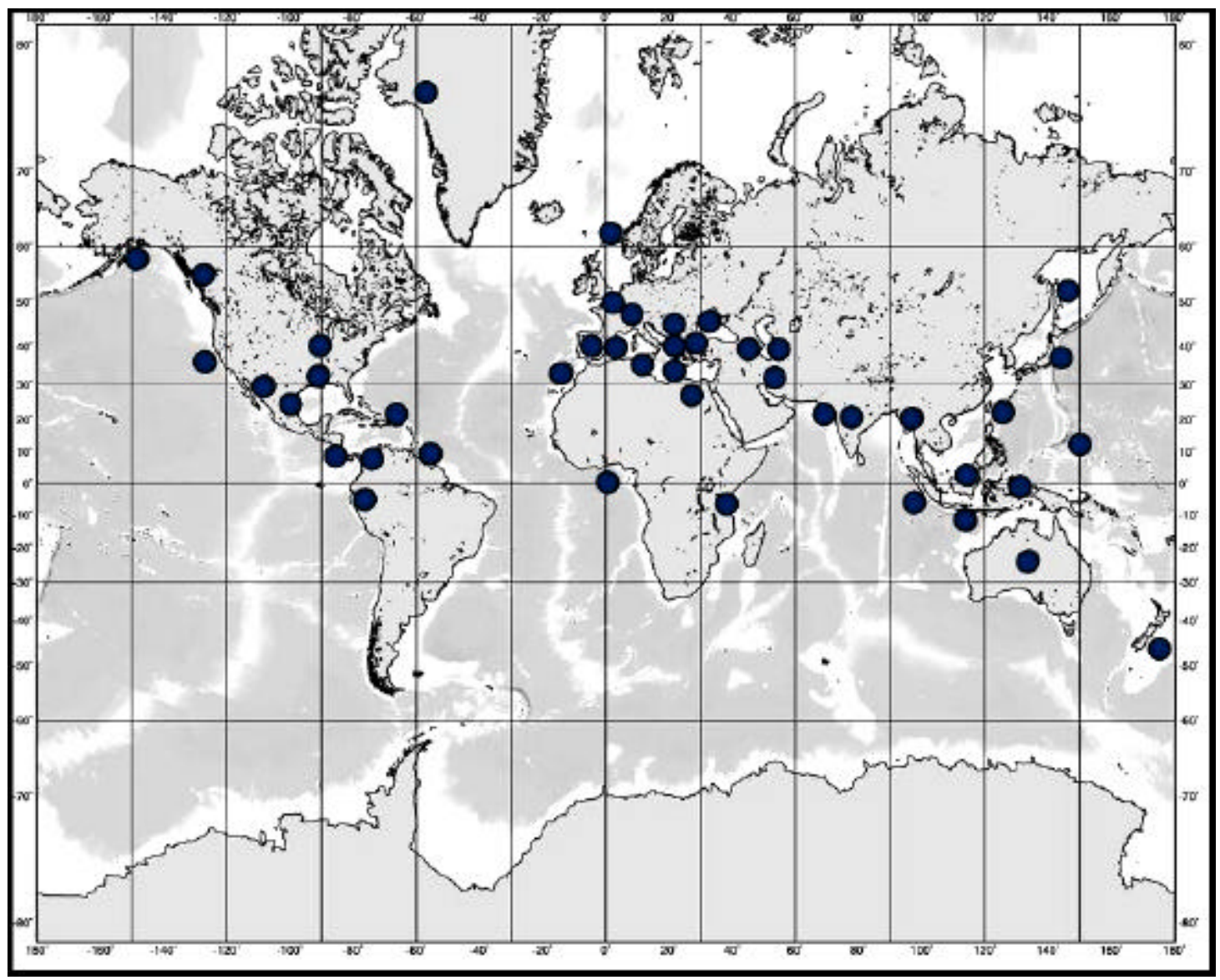

Figure 22. Distribution of mud volcanoes on Earth. Adopted from A.J. Kopf, 2002. 
by Goubkin (1934) explained the mechanism of mud volcano formation in Azerbaijan and was widely accepted among other scholars. He believed that since Akchagyl time overpressure builds conditions for plastic shale movement up to the dome of the structures. Water, gas and later oil began to migrate in the same direction concentrating on the top of the growing structure, where fracturing and faulting of the overburden rocks provide a passage for the gas and water to escape. Some amount of the fluid reaches the surface and forms a natural seepage. When the rate of gas supply becomes so high that its discharge is no longer sufficient the greatest pressure builds up on top of the structure. This stress is released as an eruption of the fluidized shale, with enormous amount of gas destroying the dome and taking surrounding rocks to the surface. Usually eruption occurs through the fault or faults system. However, even little cracks or fractures within the overburden rocks could be enough for the triggering the mud volcano mechanism.

By definition diapirism is the process of movement of a plastic body from areas of greater pressure to areas of less pressure. Therefore, diapirs are bodies of fine-grained sediments produced by the plastic deformation that are capable to deform and rupture overlying rocks. They usually have rather intrusive nature, whereas mud volcanoes are characterized by the extrusive mechanism of a moving mass. In addition, mud diapirism is described mainly as a slow process of a movement of a plastic rock over an instantaneous event in a mud volcano case.

Many mud volcanoes develop in the crest of the diapirs (Dimitrov, 2002). It is also true that most of the studies of mud volcanoes in Azerbaijan were made from 
onshore observations where mud diapirism was confirmed not only by seismic methods but also by numerous wells available for analysis. However, there are many examples when mud volcanoes are not connected with diapirs (Dimitrov, 2002). In this case, the term diatreme is used. It is type of mud extrusive feature that evolve from the violent eruption of overpressured mud, cross-cutting the overlying strata like a dyke (Kopf, 2002). Mud diapirs and diatremes are neatly distinguished on the grounds of the mechanical stress and the mud intrusions that they originate.

In offshore realms of Azerbaijan, the only data is extensive 2D and 3D seismic acquisition. Seismic data acquired across the mud volcanoes showed enormous parabolic, diapir like zones of signal distortion. From a conventional point of view on mud volcanism in Azerbaijan, a seemingly obvious conclusion was that the diapirs compose the core of mud volcanoes (Guliyev and Feyzullayev, 1995; Jakubov et al., 1971). Regional compression was invoked to attribute to a weak material of almost incomprehensible strength to pierce huge columns of rock. It could be very difficult to initiate such a system, where mechanical objections were not considered. The recent models suggest that mud diapirs were initiated during the deposition of the Lower Productive Series in Late Miocene time and underwent repeated intermittent inflation (Cooper, 2001). Such a model would require thinning of the syndepositional sedimentary series across the rising high. In this particular study, after careful examination of the strata attached to the discontinuous zone of weak reflections syndepositional thinning was not detected. The majority of mud volcanoes are related to the regional deep fault systems along with shallower listric and normal faults. Such a setting suggests that mud 
volcanoes in this area form due to instantaneous event of pressure release through diatremes.

Mud volcano formation is controlled by several factors including, recent tectonic activity, particularly compressional settings, sedimentary or tectonic loading due to rapid sedimentation, continuous hydrocarbon generation, and existence of fine-grained plastic sediments. All of these factors prevail in the South Caspian Basin. However, it is crucial to understand the origin of these forces in order to reveal the mechanism of mud volcanism in the region.

The South Caspian Basin is known for its abnormally high formation pressures. The formation of overpressure is controlled by two major factors. The first factor is the relative isolation of rocks from the effects if fluid flow. The second factor is the change of either fluid volume and / or pore volume that may occur during the burial history of a given sequence of rocks. There are three major mechanisms that result in the development of abnormal high formation pressure: 1) sedimentation, 2) hydrocarbon generation, 3) the vertical migration of fluids. In a broader sense there are numerous ways to create anomalous subsurface pressure. They include:

Nonequilibrium compaction is believed to be the dominant mechanism in formation of overpressured sediments. During burial and compaction, water is physically expelled from sediments. In thick, rapidly deposited fine-grained sections reductions in porosity and permeability related to compaction inhibit the flow of water out of the shale. As burial continues, fluid pressure increases in response to bearing the increasing weight of the overburden. 
Tectonic compression creates abnormal pressure similar to the nonequilibrium compaction mechanism. Horizontal compressive forces, directed at zones of low porosity and permeability act on the pore fluids and cause pore pressure to increase.

Aquathermal pressuring occurs when increasing temperature with depth of burial causes pore waters to expand at a greater rate than the rock. If pore waters are prevented from escaping by the flow barrier, pore pressure will increase.

Transformation of smectite to illite refers to the fact that at a temperature of about $221 \mathrm{~F}$, smectite, which is a mineral composing shale, begins altering to illite and expels a large volume of water. This way, if the rock is sealed, expelled water combined with the thermal expansion of the pore fluids will increase the formation pressure.

Hydrocarbon generation is thought to be the next major contributor after compaction forces to the pressure increase in the formation rocks. The generation of hydrocarbons involves the transformation of kerogen in organic matter into liquid and gaseous phases. This transformation results in an increase in fluid volume of the organic matter that will lead to the growth of formation pressure.

Other types of mechanisms that evolve in increase formation pressure are Osmosis, Reverse Osmosis, Gypsum/anhydrite transformation, Buoyancy, Irregularities in the potentiometric surface and Isolation and uplift of deep, gas-filled compartments. These mechanisms may contribute to the overall increase of the pressure within the sediments but their influence is rather minimal (if any) to the magnitude of overpressure.

Field data show the presence of unaltered montmorillonite in deposits around Baku Archipelago at depth down to $6 \mathrm{~km}$ (Buryakovsky et al., 1995). That indicates a 
subordinate role of montmorillonite dehydration in the total process of abnormal formation pressure development. Luo et al. (1994) conclude that most of the pore-fluid generating mechanisms (illite to smectite transformation, aquathermal expansion, kerogen maturation) contribute little to overpressure increase. Kerogen to gas or oil to gas transition produce significant volume changes (Rensbergen et al., 1999). In addition, Forbes et al. (1992) and Sandal (1996) report that even thin units of a rock can form effective permeability barriers. Faults of limited throw and relatively thin shale beds can maintain high pressure differences for a relatively long time.

The stratigraphic section of the South Caspian Basin consists of a high percentage of the fine-grained matrix (Figure 6). Sand succession highly interbedded by shales and silts. Moreover, sediments that are brought by the Kura river have poor reservoir quality due to high content of a silt material. Azeri scientists are inclined to believe that mud volcanism in Azerbaijan is related only to the Maykop plastic shale succession (Guliyev and Feyzullayev, 1995; Jakubov et al., 1971), a theory confirmed by the analyses of rocks sampled around onshore mud volcanoes. However, in offshore where Maykop lies at depth of about $12 \mathrm{~km}$, it would require extreme high pressures to overcome the overburden and instantaneously break through to the surface. More likely, due to shaly nature of the stratigraphic section, the mud volcano activity is not always related to the Maykop shale succession. Mud volcanism can occur from a shallower depth from any stratigraphic zone that can accommodate and store the great pressure and have sufficient plasticity to be transported to the surface. 
Compressional settings are also important in mud volcano formation and development. The map of distribution of the mud volcanoes (Figure 15) illustrates the position of these features along the regional structural trends (compare Figure 15 with the Figure 2). The general occurrence of the mud volcanoes above the structural crest also suggests that their origin is due to structural growth. The appearance of mud volcanoes on the flanks of the structures is usually associated with faults that detach subsurface structure. Such observations may reveal violent escape of the fluidized and highly overpressured material through the faults and cause of the seal failure. The existence of growth faults with a curved shaped at the seabed (ring faults) are connected to the mud volcanoes. Consequently the question arises whether the mud volcanoes are triggered by the activity of these faults, or conversely is there any connection at all. Graue (2000) in his work on mud volcanoes in Nigeria suggests that sudden pressure release associated with eruption will cause trembling of undercompacted shale at the root and the liquefied and gasified mud subsequently flows up the vent. This explains the distorted seismic image in the root zone. The rapid kinetics of such an eruption causes rapid depletion of pressure to a level bellow the fracture pressure of the seal. It is the point when the roof collapses into the vent and plugs the conduit to the surface. This collapse is believed to account for the concentric faults and the dipping section seen on the seismic data (Figure 13). This model proposes that eruption triggers spontaneous activity along the listric faults. Contraction occurs at the base, with corresponding fault displacement up section (Graue, 2000). In addition, use of seismic coherency attributes and mapping the fault pattern illustrate that mud volcanoes in the South Caspian Basin 
occur strictly in areas of local tension and within regional compressive fields (Cooper, 2001).

Syncline mud volcanoes observed in this study may be good indicators of a relationship of a mud volcanism with the regional compressional fields. First of all, these features occur mainly in the south, where the high density of subsurface structures suggests intense structural growth, therefore highly active compressional settings. It is plausible to expect that due to the great magnitude of lateral compression the fluidized mud overcomes fracture pressure and breaks the seal immediately in place of its origin, rather than to transmit the pressure to the top of the structure. Furthermore, the analysis of the location of a northern syncline mud volcano is important. This mud volcano is situated between two structural trends directed south-east and south-west respectively (compare Figures 2 and 19), implying that this area has undergone compression from both sides with an opposite direction. From a stratigraphic point of view this location is influenced by deposition of two different river systems. From the north it is the Volga River that in this particular location is represented by fine-grained sediments of distal delta deposits. From the west it is the silty and muddy deposits of the Kura River. Therefore, the highly overpressured succession of predominantly fine-grained plastic sediments being compressed by the lateral tectonic load overcame the seal capacity of the overburden and formed this remarkable volcano. In addition, this mud volcano is the oldest extrusive feature that was detected by this study (refer to the series of maps on Figure 21). Its activity most probably began in Sabunchi time and continued through present. 
Example of mud volcanoes over the Shah Deniz structure, offshore Azerbaijan (Fowler, 2000) shows that the time of their activity offsets the beginning of structural growth in the beginning of Akchagyl time. Therefore, one can expect a relationship of the mud volcano formation with the major elements of petroleum system. The lack of regional pressure data confines the possibility to compare the pulses of structural growth and mud volcano activity in this region. However, knowledge of the other elements of petroleum system may reveal some clues to the prevailing factors of the mud volcanism in South Caspian Basin.

Since the middle Pliocene time at about 4-5 MY ago sedimentation rate in South Caspian Basin substantially increased and reached turbidite values (Lerche et al., 1997). Approximately 2 MY ago the Azerbaijan part of the South Caspian Basin had undergone the next pulse of rapid sediment load. When these sedimentation rates are compared with the timing of activity of mud volcanoes it becomes apparent that the first pulse of mud volcano activity in the Uppermost Surakhany offsets the major pulse of sediment load. The later event of an increase in sediment supply also coincides with the peak of mud volcano activity in Upper Akhagyl time.

Lerche et al. (1997) after analyzing the data from 18 wells, together with numerical modeling of different elements of petroleum systems, concluded that the major episode of hydrocarbon generation, migration and accumulation of excessive pressure within the South Caspian Basin occurred between 3-1 MY with the emphasis to the interval of 1.8 MY. This coincides with the major increase in activity of mud volcanoes with a large increase around Upper Akchagyl (1.8 MY). 
The direction of the lateral pressure gradients after massive deposition of the Pliocene sediments is primarily to the northeast from the central portion of the basin, with secondary drives to the northwest and southwest. Accounting for the lack of data (only 18 wells) and huge approximation and extrapolation of the pressure contours it is quite difficult to expect a nice match between these trends and evolution of the mud volcanoes obtained in this study. However, there is certain trend can be seen regarding the evolution of the mud volcanoes that is consistent with conclusions of Lerche (1999).

The cyclicity of mud volcano evolution in the South Caspian Basin by itself is very important aspect of mud volcano development. Based on several studies on mud volcanoes in Trinidad and Nigeria, in addition to the studies of mud flows at Shah Deniz structure, it is possible to differentiate three stages of mud volcano development (Graue, 2000; Barboza and Boettcher, 2000; Boettcher et al., 2000; Fowler, 2000).

Stage 1 - Eruption. Hydraulic failure of strata within the overpressured stratigraphic section.

Stage 2 - Depletion. Migration of gas, oil and water to the surface from cracks, mudflow and adjacent porous strata.

Stage 3 - Quiescence and build-up. Accumulation of primary and/or secondary overpressure.

These stages may reflect the development of the mud volcanoes in the South Caspian. Each cycle shown in Figure 20 clearly distinguished the periods of maximum activity, depletion and quiescence. Therefore, the general pattern of development of the 
mud volcanoes observed globally is influenced by similar factors of the seal failure, gas supply and pressure build-up.

The different morphology of mud volcanoes could be explained by differences in physical properties of material supplied, by the frequency of eruptions or it could represent different stages of mud volcano development. In the literature there are many terms that describe the shape and seize of mud volcanoes (Cooper, 2001; Graue, 2000; Guliyev and Feyzullayev, 1995; Kopf, 2002; Dimitrov, 2002). Some terms are referred to as mud cones, mud pies, domes and craters. The distinctive type of mud volcano with a negative surface expression is called a mud pool, when extruded material is so fluidized and gassy that it collapses into the crater and fills the depression. Simple rules appear to apply to the formation of different shapes of the mud volcanoes. The higher the pore-fluid pressure, the more violent the eruption; the more frequent the activity, the larger the structure; the lower the viscosity, the larger and flatter the body. Mud with low porosities form mud domes or ridges, more consistent mud with intermediate fluid content can give rise to mud volcanoes with large diameters and elevation above the sea floor, and high porosity mud creates mud pies with the great areal extent. Summarizing the general knowledge of mud volcano geometry it is possible to conclude that the size of mud volcano is mainly a function of the size of the conduit and the driving force of the mud volcanism in the area. Large features are generally thought to have a wide conduit and efficient trigger at depth (Kopf, 2002). In addition, the consistency of the mud is suggested to be the controlling parameter for the height of the mud volcano. Analog modeling of mud volcanism in the laboratory has yielded flat mud pies for wide 
feeders and cones for narrowing feeders when using the same material (Lance et al., 1998).

There are instances when mud volcanoes are spaced very close to each other and form a common body. The mud flows from such system can cover areas of 100 square kilometers. It is especially true for the mud volcanoes in the South Caspian Basin, where extensive morphological features have several mud volcanoes associated with them.

The attempt to classify mud volcanoes based on the character of eruption with regard to the surface expression was made by Kalinko (1964). He distinguishes three classes of mud volcanoes:

First class - Lokbatan type. Well formed steep conical shape of mud volcanoes of this type.

Second class - Chikishlyar type. The mud volcanoes of this type form very low, bulged or flat domes, which merge with the surrounding plane, or they form plateshaped depressions that are filled by water.

Third class - Schugin type. Characterized by a great variety of forms, but most common the mud volcanoes of this type create composite craters.

In this study the convex shape of the mud volcanoes within the Caspian Sea may be classified as the Lokbatan type, flat mud volcanoes as Chikishyar type and convex shaped mud volcanoes as Schugin type. Buried mud volcanoes can be distinguished as a separate type, since they do not have a surface manifestation. The areal distribution of the mud volcanoes of different shapes does not reveal any noticeable trend. Most 
commonly, all types of mud volcanoes can be observed in a volcano belt of mud volcanoes.

The different morphology of the mud volcanoes may also be related to the different stages in its development. At the first stage of the mud volcano evolution one can expect a product of violent eruption manifesting itself by creating a large crater and a huge amount of mud and parts of rocks deposited on the sides. Then during the time of fluid migration the crater can be filled by the mud, or in the case of more dense material, it could form a dome- like feature. Later stages of quiescence may result in subsidence of the feature and formation of a very low dome that would eventually merge with the surrounding plane. However, this does not mean that this process is controlling the geometry of the mud volcanoes. It may have a relationship with the general and widely accepted point of view, described above, such as a relationship with the density of material and frequency of eruptions (Guliyev and Feyzullayev, 1995; Kopf, 2002; Cooper, 2001; Graue, 2000; Dimitrov, 2002).

Summarizing everything above the following are the major conclusions drown from the analysis and interpretation of the data as well as the extensive literature research:

- Mud volcanism in South Caspian offshore is associated with the fluid pressure gradient (diatremes) in the subsurface.

- Differences in morphology may be due to the relationship between driving force (pressure) and material supply, width of conduit or could represent different stages in mud volcano evolution. 
- Mud volcanoes occur strictly in areas of local tension, within regional compressional fields.

- Mud Volcano formation in the offshore South Caspian is mainly controlled by tectonic forces and overpressured sediments.

- Mud volcano activity is not always related to the Maykop shale succession. It can occur at shallow depths by pressure breakthrough from any stratigraphic zone.

- The cycles of mud volcano activity in the South Caspian Basin coincides with the time of high sedimentation rate, a regional contraction episode, and major stage for hydrocarbon generation.

- There is no relationship between the mud volcano parameters such as size, shape areal extent etc., and their distribution. 


\section{REFERENCES CITED}

Abdullayev, N. R., 2000, Seismic stratigraphy of the Upper Pliocene and Quaternary deposits in the South Caspian Basin: Journal of Petroleum Science and Engineering, no 28, p. 207-226.

Abich, O. W. H., 1863, Uber eine im Caspischen Meere erschienene Insel, nebst Beitragen zur Kenntniss der Schlammvulkane der Caspischen Region: Memoir of Academy Imperial Science, St. Petersburg, ser. 7, T6(5), 183 p.

Abrams, M. A., and A. A. Narimanov, 1997, Geochemical evaluation of hydrocarbons and their potential sources in the western South Caspian depression, Republic of Azerbaijan: Marine and Petroleum Geology, v. 14, no. 4, p. 451-468.

Allen, M. B., S. J. Vincent, G. I. Alsop, A. Ismail-zadeh, and R. Flecker, 2003, Late Cenozoic deformation in the South Caspian region: effects of a rigid basement block within a collision zone: Tectonophysics, v. 366, p. 223-239.

Barboza, S. A., and S. S. Boettcher, 2000, Major and trace element constraints on fluid origin, offshore Eastern Trinidad: Proceedings of SPE 2000 Conference, Port-ofSpain, Trinidad, $11 \mathrm{p}$.

Belopolsky, A., M. Talwani, and D. L. Berry, 1998, Geology and petroleum potential of the Caspian region: The Center for Political Economy and the James A. Baker III Institute for Public Policy, Rice University, Houston, TX, 34 p. 
Berberian, M., 1983, The Southern Caspian: a compressional depression floored by a trapped, modified oceanic crust: Canadian Journal of Earth Science, v. 20, p. $163-183$.

Berberian, M., and G. P. King, 1981, Towards a paleogeography and tectonic evolution of Iran: Canadian Journal of Earth Science, v. 18, p. 210-265.

Boettcher, S. S., J. L. Jackson, J. E. Neal, and M. J. Quinn, 2000, Lithosphere-scale cross section and tectonic synthesis, offshore Eastern Trinidad: Proceedings of SPE 2000 Conference, Port-of-Spain, Trinidad, 14 p.

Brown, K. M., 1990, Nature and hydrogeologic significance of mud diapirs and diatrimes for accretionary systems: Journal of Geophysical Research, v.95, p. 8969-8982.

Bulin, N. K., 1978, New ideas on crust structure (from seismic data): International Geology Reviews, v. 20, p. 887-889.

Buryakovsky, L. A., R. D. Djevanshir, and G. V. Chilingar, 1995, Abnormally-high formation pressures in Azerbaijan and the South Caspian Basin (as related to smectite - illite transformations during diagenesis and catagenesis): Journal of Petroleum Science and Engineering, v. 13, p. 203-218.

Cooper, C., 2001, Mud volcanoes of the South Caspian Basin - seismic data and implications for hydrocarbon systems: AAPG Bulletin, v. 85, no. 13, p. 231-245.

Croissant, C., 1998, Azerbaijan oil and geopolitics: Nova Science Publishers, Commack, New York, 117 p.

Cullen, R., 1999, The Caspian Sea: National Geographic, v. 195, no. 5, p. 2-35. 
Daniloff, R., 1998, Waiting for the oil boom: Smithsonian, v. 28, no. 10, p. 24-35.

Dimitrov, L. I., 2002, Mud volcanoes - the most important pathway for degassing deeply buried sediments: Earth-Science Reviews, v. 59, p. 49-76.

Forbes, P. L., P. Ungerer, and B. S. Mudford, 1992, A two-dimensional model of overpressure development and gas accumulation in Venture field, Eastern Canada: AAPG Bulletin, v. 76, p. 318-338.

Fowler, S. R., J. Mildenhall, and S. Zalova, 2000, Mud volcanoes and structural development on Shah Deniz: Journal of Petroleum Science and Engineering, no. 28 , p.189-206.

Galperin, Y., I. Kosminskaya, and P. Krakshina, 1962, Main characteristics of deep waves recorded during deep seismic sounding in the central part of the Caspian Sea, Deep Seismic Sounding of the earth's crust in the U.S.S.R.: Academy of Science of U.S.S.R., Moscow, p. 167-186.

Goubkin, I., 1934, Tectonics of South-East Caucasus and its relation to the productive oilfields: AAPG Bulletin, v. 18, p. 603-671.

Graue, K., 2000, Mud volcanoes in deep water Nigeria: Marine and Petroleum Geology, v.17, p. 959-974.

Guliyev, I. S., and A. A. Feizullayev, 1995, All about mud volcanoes: Institute of Geology of the Azerbaijan Academy of Sciences, Baku, 52 p.

Jackson, J., K. Priestley, M. Allen, and M. Berberian, 2002, Active tectonics of the South Caspian Basin: Geophysical Journal International, v. 148, p. 214-245. 
Jakubov, A. A., A. A. Ali-Zade, and M. M. Zeynalov, 1971, Mud volcanoes of the Azerbaijan SSR: Academy of Science of the Azerbaijan SSR, Baku, 257 p.

Kalinko, M., 1964, Mud volcanoes, reasons of their origin, development and fading: VNIGRI, v. 40, p. 30-54 (in Russian).

Katz, B., D. Richards, D. Long, and W. Lawrence, 2000, A new look at the components of the petroleum system of the South Caspian Basin: Journal of the Petroleum Science and Engineering, v. 28, p.161-182.

Khalilov, E. N., S. F. Mekhtiyev, and V. Y. Khain, 1987, Some geophysical data confirming the collisional origin of the Greater Caucasus: Geotectonics, v. 21, p. $132-136$.

Kopf, A. J., 2002, Significance of mud volcanism: Reviews of Geophysics, v. 40, no. 2, p. 2.1-2.52.

Kulshin, V., 1845, Die Schlammvulcane der Krym: Arch. Wiss. Russ., v. 4, p. 130-134.

Lance, S., P. Henry, X. Le Pichon, S. Lallemant, H. Chamley, F. Rostek, J. Faugeres, E. Conthier, and K. Olu, 1998, Submersible study of mud volcanoes seaward of the Barbados accretionary wedge: sedimentology, structure and rheology: Marine Geology, v. 145, p. 255-292.

Lebedev, L. I., I. A. Aleksina, and L.S. Kulakova, 1987, Caspian Sea geology and oil and gas potential: Nauka, Russian Academy of Science, Moscow, 295 p. (in Russian).

Lerche, I., and E. Bagirov, 1999, Impact of natural hazards on oil and gas extraction, the South Caspian Basin: Kluwer Academic / Plenium Publishers, New York, 353 p. 
Lerche, I., E. Bagirov, F. Nadirov, M. Tagiyev, and I. Guliyev, 1997, Evolution of the South Caspian Basin: geologic risks and probable hazards: Institute of Geology of Azerbaijan Academy of Sciences, Baku, 580 p.

Lorenz, V., 1975, Formation of phreatomagmatic maar-diatreme volcanoes and its relevances to kimberlite diatremes: Physical Chemistry of Earth, v. 9, p. 17-27.

Luo, M., M. R. Baker, and D. V. LeMone, 1994, Distribution and generation of the overpressure system, eastern Delaware Basin, western Texas and southern New Mexico: AAPG Bulletin, v. 78, p. 1386-1405.

Maksimova, S. P., 1987, Oil and gas deposits of the USSR. Asiatic part of USSR: Moscow, Nedra Press (in Russian), v. 2, p. 69-110.

Mangino, S., and K. Priestley, 1998, The crustal structure of the southern Caspian region: Geophysical Journal International, v. 133, p. 630-648.

Milkov, A. V., 2000, Worldwide distribution of submarine mud volcanoes and associated gas hydrates: Marine Geology, v. 167, p. 29-42.

Nadirov, R. S., E. Bagirov, and M. Tagiyev, 1997, Flexural plate subsidence, sedimentation rates, and structural development of the super-deep South Caspian Basin: Marine and Petroleum Geology, v. 14, p. 383-400.

Narimanov, A. A., and I. Palaz, 1995, Oil history, potential converge in Azerbaijan: Oil and Gas Journal, May 22, p. 32-39.

Neprochnov, Y. U., 1968, Structure of the earth's crust of epicontinental seas: Caspian, Black and Mediterranean: Canadian Journal of Earth Science, v. 5, p. 1037-1043. 
Philip, H., A. Cisternas, A. Gvishian, and A. Gorshkov, 1989, The Caucasus: an actual example of the initial stages of continental collision: Tectonophysics, v. 161, p. 1-21.

Rabinowitz, P. D., M. Z. Yusifov, J. Arnoldi, and E. Hakim, 2004, Geology, oil and gas potential, pipelines, and the geopolitics of the Caspian Sea Region: Ocean Development and International Law, v. 35, p. 19-40.

Rensbergen, P. V., C. K. Morley, D. W. Ang, T. Q. Hoan, and N. T. Lam, 1999, Structural evolution of shale diapirs from reactive rise to mud volcanism: 3D seismic data from the Baram delta, offshore Brunei Darussalam: Journal of the Geological Society, London, v. 156, p. 633-650.

Reynolds, A. D., and M. D. Simmons, 1998, Implications of outcrop geology for reservoirs in the Neogene Productive Series: Apsheron Peninsula, Azerbaijan: AAPG Bulletin, v. 82, no. 1, p. 25-49.

Rezanov, I. A., and S. S. Chamo, 1969, Reasons for absence of a granitic layer in basins of the South Caspian and Black Sea type: Canadian Journal of Earth Science, v. 6, p. 671-678.

Ryaboy, V., 1969, Structure of the Earth's crust in the central regions of Turkmenia according to deep seismic sounding data: Proceedings of $8^{\text {th }}$ Assembly European Seismic Commission, p. 216-221.

Sagers M. J., and J. R. Matzko, 1993, The oil resources of Azerbaijan, survey and current developments: International Geology Review, v. 35, p. 1093-1103. 
Sandal, S. T., 1996, The geology and hydrocarbon resources of Negara Brunei Darussalem (1996 revision): Brunei Shell Petroleum Company/Brunei Museum, Syabas Bandar Seri Begawan, Brunei Darussalem.

Sengor, A. M. C., 1990, A new model for the late Paleozoic-Mesozoic tectonic evolution of Iran and implications for Oman, the geology and tectonics of the Oman region: Geological Society of London Special Publication, no. 49, p. 797-831.

Shikalibeily, E. Sh., and B. V. Grigoriants, 1980, Principal features of the crustal structure of the South Caspian Basin and the conditions of its formation: Tectonophysics, v. 69, p. 113-121.

Yegorkin, A. V., and B. A. Matushkin, 1970, Crustal structure of the Caucasus and Western Central Asia based on geophysical sounding data: International Geology Reviews, v. 12, p. 281-290.

Zonenshain, L.P., and X. Le Pichon, 1986, Deep basins of the Black Sea and Caspian Sea as remnants of Mesozoic back-arc basins: Tectonophysics, v.123, p. 181-211. 
APPENDIX A

\section{DATABASE FOR ANALYZED MUD VOLCANOES WITHIN THE AREA OF STUDY}

\section{Legend:}

\begin{tabular}{|l|l|}
\hline $\mathbf{x}$ & Clear presence of determined parameter \\
\hline $\boldsymbol{?}$ & Probable presence of determined parameter \\
\hline
\end{tabular}




\begin{tabular}{|c|c|c|c|c|c|c|c|c|c|c|c|}
\hline \multirow{2}{*}{$\begin{array}{c}\text { Mud } \\
\text { Volcanoes } \\
\text { (MV) }\end{array}$} & \multicolumn{4}{|c|}{ Size } & \multirow{2}{*}{$\begin{array}{l}\text { Shape of } \\
\text { the MV }\end{array}$} & \multicolumn{3}{|c|}{ Seismic Artifacts } & \multirow{2}{*}{$\begin{array}{l}\text { Relation to } \\
\text { the structure }\end{array}$} & \multirow{2}{*}{$\begin{array}{l}\text { Collapse } \\
\text { structure }\end{array}$} & \multirow[b]{2}{*}{ Faulting } \\
\hline & $\begin{array}{l}\text { Length } \\
\text { (m) }\end{array}$ & $\begin{array}{l}\text { Width } \\
\text { (m) }\end{array}$ & $\begin{array}{c}\text { area } \\
\text { (sq.km) }\end{array}$ & $\begin{array}{l}\text { height } \\
\text { (m) }\end{array}$ & & $\begin{array}{c}\text { Wipeout } \\
\text { zone }\end{array}$ & Multiples & $\begin{array}{c}\text { Pulldown } \\
\text { effect }\end{array}$ & & & \\
\hline 1 & 4361 & 3180 & 10.79 & 132 & Convex & Strong & $x$ & & Side & $x$ & $x$ \\
\hline 2 & 737 & 683 & 1.96 & 23 & Concave & Weak & & & Syncline & $x$ & $x$ \\
\hline 3 & 1587 & 1587 & 4.5 & 74 & Flat & Strong & $x$ & & Side & & \\
\hline 4 & 4608 & 3038 & 14.97 & 0 & Buried & Weak & & & Crest & & $x$ \\
\hline 5 & 5110 & 4030 & 21.42 & 0 & Buried & Weak & & & Crest & & \\
\hline 6 & 3256 & 2594 & 8.26 & 122 & Convex & Strong & & $x$ & Side & $x$ & $x$ \\
\hline 7 & 2719 & 2081 & 4.28 & 99 & Flat & Strong & $x$ & & Side & & \\
\hline 8 & 9560 & 2810 & 24.33 & 130 & Convex & Weak & $x$ & $x$ & Crest & $x$ & $x$ \\
\hline 9 & 1568 & 1570 & 2.4 & 55 & Convex & Weak & & & Crest & & $x$ \\
\hline 10 & 3921 & 3408 & 10.76 & 148 & Convex & Weak & $x$ & & Side & $x$ & \\
\hline 11 & 3210 & 1110 & 3.11 & 65 & Flat & Strong & $x$ & & Crest & $x$ & $x$ \\
\hline 12 & 1568 & 1568 & 2.47 & 0 & Buried & Weak & & & Side & & $x$ \\
\hline 13 & 1389 & 1389 & 2.13 & 92 & Convex & Weak & $x$ & & Syncline & & \\
\hline 14 & 2807 & 2159 & 5.12 & 101 & Convex & Weak & & & Crest & $x$ & $x$ \\
\hline 15 & 5222 & 4272 & 18.12 & 113 & Convex & Weak & & & Side & & $x$ \\
\hline 16 & 5214 & 3926 & 14.41 & 184 & Flat & Strong & $x$ & & Side & & $x$ \\
\hline 17 & 1618 & 1492 & 2.5 & 178 & Convex & Weak & & & Side & $x$ & $x$ \\
\hline 18 & 8830 & 2222 & 21.18 & 194 & Concave & Strong & $x$ & & Crest & & \\
\hline 19 & 2526 & 1662 & 4.28 & 0 & Buried & Weak & & & Side & & \\
\hline 20 & 1213 & 1213 & 1.61 & 0 & Buried & Strong & & & Syncline & & $x$ \\
\hline 21 & 2583 & 1543 & 4.42 & 0 & Buried & Strong & & $x$ & Side & & $x$ \\
\hline 22 & 6071 & 3817 & 18.4 & 136 & Convex & Strong & $x$ & & Side & & $x$ \\
\hline 23 & 4369 & 2663 & 9.47 & 145 & Convex & Strong & $x$ & & Side & & $x$ \\
\hline
\end{tabular}




\begin{tabular}{|c|c|c|c|c|c|c|c|c|c|c|c|}
\hline \multirow{2}{*}{$\begin{array}{c}\text { Mud } \\
\text { Volcanoes } \\
\text { (MV) }\end{array}$} & \multicolumn{4}{|c|}{ Size } & \multirow{2}{*}{$\begin{array}{l}\text { Shape of } \\
\text { the MV }\end{array}$} & \multicolumn{3}{|c|}{ Seismic Artifacts } & \multirow{2}{*}{$\begin{array}{l}\text { Relation to } \\
\text { the structure }\end{array}$} & \multirow{2}{*}{$\begin{array}{l}\text { Collapse } \\
\text { structure }\end{array}$} & \multirow[b]{2}{*}{ Faulting } \\
\hline & $\begin{array}{l}\text { Length } \\
\text { (m) }\end{array}$ & $\begin{array}{c}\text { Width } \\
(\mathrm{m})\end{array}$ & $\begin{array}{c}\text { area } \\
\text { (sq.km) }\end{array}$ & $\begin{array}{l}\text { height } \\
\text { (m) }\end{array}$ & & $\begin{array}{c}\text { Wipeout } \\
\text { zone }\end{array}$ & Multiples & $\begin{array}{c}\text { Pulldown } \\
\text { effect }\end{array}$ & & & \\
\hline 24 & 2952 & 2306 & 6.15 & 0 & Buried & Weak & & & Side & $x$ & $x$ \\
\hline 25 & 3290 & 2982 & 7.93 & 0 & Buried & Weak & & $x$ & Syncline & & $x$ \\
\hline 26 & 953 & 953 & 0.9 & 10 & Convex & Weak & & $x$ & Side & & \\
\hline 27 & 2265 & 2080 & 3.42 & 94 & Convex & Weak & & & Crest & & $x$ \\
\hline 28 & 1185 & 1084 & 1.02 & 84 & Convex & Weak & & & Crest & & $x$ \\
\hline 29 & 3817 & 3437 & 12 & 157 & Convex & Weak & & & Side & $x$ & $x$ \\
\hline 30 & 2792 & 2275 & 5.75 & 151 & Convex & Strong & & & Crest & & $x$ \\
\hline 31 & 4072 & 3390 & 9.7 & 62 & Convex & Weak & & & Crest & $x$ & $x$ \\
\hline 32 & 2208 & 2208 & 5.18 & 105 & Convex & Weak & $x$ & & Side & $x$ & $x$ \\
\hline 33 & 13791 & 5820 & 90 & 237 & Convex & Strong & $x$ & & Crest & $x$ & $x$ \\
\hline 34 & 10151 & 6921 & 54.87 & 246 & Flat & Strong & $x$ & & Crest & & $x$ \\
\hline 35 & 8626 & 7434 & 54 & 32 & Convex & Weak & $x$ & & Crest & $x$ & $x$ \\
\hline 36 & 5611 & 5293 & 24.72 & 157 & Convex & Strong & $x$ & & Crest & $x$ & $x$ \\
\hline 37 & 4835 & 4061 & 18.41 & 187 & Flat & Strong & $x$ & & Crest & $x$ & $x$ \\
\hline $38 a$ & 3917 & 3200 & 10.68 & 76 & Flat & Strong & $x$ & & Crest & $x$ & $x$ \\
\hline $38 b$ & 774 & 774 & 0.43 & 71 & Convex & Weak & & & Crest & $x$ & $x$ \\
\hline 39 & 333 & 333 & 0.1 & 34 & Convex & Weak & & & Crest & & $x$ \\
\hline 40 & 4179 & 4125 & 9.32 & 13.8 & Flat & Strong & $x$ & & Crest & & $x$ \\
\hline 41 & 1053 & 1053 & 0.8 & 50 & Convex & Strong & & & Crest & & $x$ \\
\hline 42 & 7748 & 4779 & 36.73 & 166 & Convex & Weak & & & Crest & $x$ & $x$ \\
\hline 43 & 7046 & 5109 & 30 & 243 & Flat & Strong & $x$ & & Crest & $x$ & $x$ \\
\hline 44 & 8145 & 5646 & 34 & 172 & Flat & Strong & $x$ & & Crest & & $x$ \\
\hline 45 & 5624 & 3543 & 16 & 106 & Flat & Strong & $x$ & & Crest & $x$ & $x$ \\
\hline
\end{tabular}




\begin{tabular}{|c|c|c|c|c|c|c|c|c|c|c|c|}
\hline \multirow{2}{*}{$\begin{array}{c}\text { Mud } \\
\text { Volcanoes } \\
\text { (MV) }\end{array}$} & \multicolumn{4}{|c|}{ Size } & \multirow{2}{*}{$\begin{array}{l}\text { Shape of } \\
\text { the MV }\end{array}$} & \multicolumn{3}{|c|}{ Seismic Artifacts } & \multirow{2}{*}{$\begin{array}{l}\text { Relation to } \\
\text { the structure }\end{array}$} & \multirow{2}{*}{$\begin{array}{l}\text { Collapse } \\
\text { structure }\end{array}$} & \multirow[b]{2}{*}{ Faulting } \\
\hline & $\begin{array}{l}\text { Length } \\
\text { (m) }\end{array}$ & $\begin{array}{c}\text { Width } \\
(\mathrm{m})\end{array}$ & $\begin{array}{c}\text { area } \\
\text { (sq.km) }\end{array}$ & $\begin{array}{l}\text { height } \\
\text { (m) }\end{array}$ & & $\begin{array}{c}\text { Wipeout } \\
\text { zone }\end{array}$ & Multiples & $\begin{array}{c}\text { Pulldown } \\
\text { effect }\end{array}$ & & & \\
\hline 46 & 3992 & 3551 & 11 & 103 & Flat & Strong & $x$ & & Crest & $x$ & $x$ \\
\hline 47 & 988 & 988 & 1 & 49 & Convex & Weak & $x$ & $x$ & Crest & & $x$ \\
\hline 48 & 843 & 567 & 0.44 & 58 & Convex & Weak & $x$ & & Side & & $x$ \\
\hline 49 & 2481 & 2336 & 4.52 & 126 & Concave & Strong & $x$ & & Crest & & $x$ \\
\hline 50 & 2200 & 2132 & 4.03 & 185 & Flat & Strong & $x$ & & Crest & & $x$ \\
\hline 51 & 688 & 688 & 0.5 & 83 & Convex & Weak & $x$ & & Crest & & $x$ \\
\hline 52 & 2053 & 2053 & 3.83 & 0 & Flat & Strong & & & Crest & & \\
\hline 53 & 5665 & 4770 & 20.18 & 427 & Concave & Strong & $x$ & & Crest & & $x$ \\
\hline 54 & 9352 & 5775 & 40.79 & 611 & Convex & Strong & $x$ & & Side & & $x$ \\
\hline 55 & 6252 & 4485 & 29.42 & 397 & Flat & Strong & $x$ & & Crest & & $x$ \\
\hline 56 & 5629 & 4992 & 20.42 & 276 & Convex & Weak & & & Crest & $x$ & $x$ \\
\hline 57 & 5917 & 4910 & 24 & 250 & Convex & Strong & $x$ & & Crest & & $x$ \\
\hline 58 & 4302 & 3756 & 13.56 & 270 & Flat & Strong & $x$ & & Crest & & $x$ \\
\hline 59 & 3658 & 2731 & 8.76 & 178 & Convex & Strong & $x$ & & Crest & $x$ & $x$ \\
\hline 60 & 4031 & 4029 & 14.22 & 258 & Convex & Weak & & $x$ & Crest & & $x$ \\
\hline 61 & 2980 & 2119 & 5.23 & 210 & Convex & Strong & $x$ & & Crest & & $x$ \\
\hline 62 & 1070 & 1070 & 1.27 & 65 & Flat & Weak & & & Crest & $x$ & $x$ \\
\hline 63 & 3282 & 3282 & 9.47 & 240 & Concave & Weak & $x$ & & Crest & & $x$ \\
\hline 64 & 11396 & 5666 & 55.46 & 258 & Flat & Strong & $x$ & $x$ & Crest & $x$ & $x$ \\
\hline 65 & 1301 & 1301 & 2.32 & 168 & Flat & Weak & & & Crest & $x$ & $x$ \\
\hline 66 & 2755 & 2755 & 6.8 & 201 & Convex & Weak & & & Crest & $x$ & $x$ \\
\hline 67 & 7424 & 3939 & 24.28 & 362 & Concave & Weak & & & Crest & & $x$ \\
\hline 68 & 12412 & 2133 & 24.89 & 228 & Concave & Weak & & & Crest & & $x$ \\
\hline
\end{tabular}




\begin{tabular}{|c|c|c|c|c|c|c|c|c|c|c|c|}
\hline \multirow{2}{*}{$\begin{array}{c}\text { Mud } \\
\text { Volcanoes } \\
\text { (MV) }\end{array}$} & \multicolumn{4}{|c|}{ Size } & \multirow{2}{*}{$\begin{array}{l}\text { Shape of } \\
\text { the MV }\end{array}$} & \multicolumn{3}{|c|}{ Seismic Artifacts } & \multirow{2}{*}{$\begin{array}{l}\text { Relation to } \\
\text { the structure }\end{array}$} & \multirow{2}{*}{$\begin{array}{l}\text { Collapse } \\
\text { structure }\end{array}$} & \multirow[b]{2}{*}{ Faulting } \\
\hline & $\begin{array}{l}\text { Length } \\
\text { (m) }\end{array}$ & $\begin{array}{c}\text { Width } \\
(\mathrm{m})\end{array}$ & $\begin{array}{c}\text { area } \\
\text { (sq.km) }\end{array}$ & $\begin{array}{l}\text { height } \\
\text { (m) }\end{array}$ & & $\begin{array}{c}\text { Wipeout } \\
\text { zone }\end{array}$ & Multiples & $\begin{array}{c}\text { Pulldown } \\
\text { effect }\end{array}$ & & & \\
\hline 69 & 2109 & 1898 & 3.84 & 270 & Convex & Weak & $x$ & & Crest & & $x$ \\
\hline 70 & 7118 & 3589 & 21.59 & 98 & Convex & Weak & & & Side & $x$ & $x$ \\
\hline 71 & 4992 & 4992 & 22.93 & 0 & Buried & Strong & & $x$ & Side & & $x$ \\
\hline 72 & 3328 & 3328 & 7.74 & 96 & Flat & Strong & $x$ & $x$ & Crest & $x$ & $x$ \\
\hline 73 & 12205 & 6507 & 50.91 & 329 & Convex & Weak & $x$ & & Crest & $x$ & $x$ \\
\hline 74 & 4207 & 3295 & 12.08 & 347 & Flat & Weak & & & Crest & & $x$ \\
\hline 75 & 3304 & 3304 & 8.02 & 356 & Concave & Weak & & & Crest & & $x$ \\
\hline 76 & 6286 & 5252 & 26.7 & 398 & Convex & Weak & & & Crest & $x$ & $x$ \\
\hline 77 & 7889 & 5031 & 32.28 & 143 & Flat & Strong & $x$ & & Crest & & $x$ \\
\hline 78 & 1064 & 1064 & 0.8 & 77 & Concave & Weak & & & Crest & & $x$ \\
\hline 79 & 10997 & 5046 & 48.35 & 124 & Flat & Weak & & & Crest & & $x$ \\
\hline 80 & 838 & 838 & 0.5 & 118 & Flat & Weak & & $x$ & Crest & & $x$ \\
\hline 81 & 1788 & 1788 & 2.42 & 0 & Concave & Weak & $x$ & & Crest & & $x$ \\
\hline 82 & 1878 & 1878 & 3.66 & 0 & Flat & Weak & & $x$ & Crest & & $x$ \\
\hline 83 & 4296 & 2306 & 9.76 & 68 & Flat & Weak & & & Crest & & $x$ \\
\hline 84 & 2768 & 2768 & 8.15 & 160 & Flat & Weak & $x$ & & Crest & & $x$ \\
\hline 85 & 560 & 560 & 0.3 & 0 & Flat & Weak & & & Crest & & $x$ \\
\hline 86 & 11653 & 6361 & 60.73 & 0 & Concave & Strong & $x$ & & Crest & & $x$ \\
\hline 87 & 3928 & 3694 & 12.43 & 157 & Convex & Strong & $x$ & $x$ & Syncline & $x$ & $x$ \\
\hline 88 & 4174 & 2474 & 9.12 & 199 & Convex & Weak & $x$ & $x$ & Crest & $x$ & $x$ \\
\hline 89 & 6185 & 4799 & 23.37 & 0 & Flat & Weak & & & Crest & & $x$ \\
\hline 90 & 5219 & 5219 & 21.47 & 0 & Flat & Weak & & $x$ & Crest & & \\
\hline 91 & 1692 & 1692 & 2.7 & 118 & Convex & Weak & & $x$ & Crest & & $x$ \\
\hline
\end{tabular}




\begin{tabular}{|c|c|c|c|c|c|c|c|c|c|c|c|}
\hline \multirow{2}{*}{$\begin{array}{c}\text { Mud } \\
\text { Volcanoes } \\
\text { (MV) }\end{array}$} & \multicolumn{4}{|c|}{ Size } & \multirow{2}{*}{$\begin{array}{l}\text { Shape of } \\
\text { the MV }\end{array}$} & \multicolumn{3}{|c|}{ Seismic Artifacts } & \multirow{2}{*}{$\begin{array}{l}\text { Relation to } \\
\text { the structure }\end{array}$} & \multirow{2}{*}{$\begin{array}{l}\text { Collapse } \\
\text { structure }\end{array}$} & \multirow[b]{2}{*}{ Faulting } \\
\hline & $\begin{array}{c}\text { Length } \\
(\mathrm{m})\end{array}$ & $\begin{array}{c}\text { Width } \\
(\mathrm{m})\end{array}$ & $\begin{array}{c}\text { area } \\
\text { (sq.km) }\end{array}$ & $\begin{array}{l}\text { height } \\
\text { (m) }\end{array}$ & & $\begin{array}{c}\text { Wipeout } \\
\text { zone }\end{array}$ & Multiples & $\begin{array}{c}\text { Pulldown } \\
\text { effect }\end{array}$ & & & \\
\hline 92 & 4714 & 3032 & 12.24 & 200 & Convex & Strong & $x$ & & Crest & $x$ & $x$ \\
\hline 93 & 4417 & 3994 & 14.11 & 133 & Convex & Weak & & $x$ & Crest & & $x$ \\
\hline 94 & 2354 & 1939 & 4.24 & 46 & Flat & Strong & $x$ & & Side & & $x$ \\
\hline 95 & 7155 & 3023 & 20.48 & 0 & Buried & Weak & & & Crest & $x$ & $x$ \\
\hline 96 & 4433 & 4091 & 14.85 & 55 & Flat & Strong & $x$ & & Crest & & $x$ \\
\hline 97 & 3148 & 3148 & 8 & 111 & Convex & Weak & & & Crest & & $x$ \\
\hline 98 & 1078 & 1078 & 9 & 175 & Convex & Weak & & & Crest & & \\
\hline 99 & 3367 & 3045 & 8.33 & 0 & Flat & Weak & & $x$ & Crest & & $x$ \\
\hline
\end{tabular}




\begin{tabular}{|c|c|c|c|c|c|c|c|c|c|c|c|c|c|}
\hline \multirow{3}{*}{ 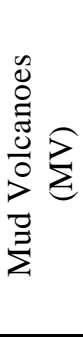 } & \multicolumn{13}{|c|}{ Time of Mud Flows } \\
\hline & 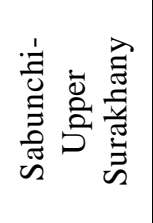 & 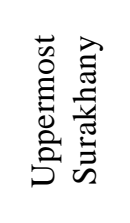 & 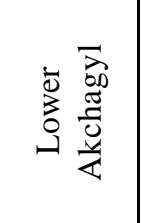 & $\sum_{\sum}^{\frac{\vec{\pi}}{20}} \frac{\vec{\pi}}{\frac{\pi}{0}}$ & 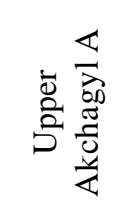 & 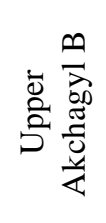 & 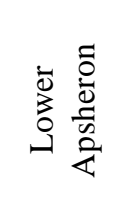 & 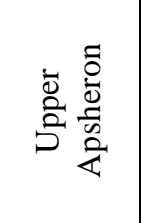 & 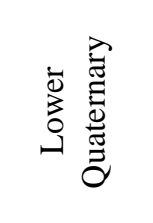 & 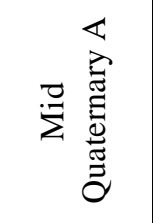 & 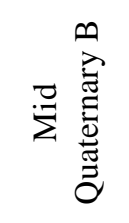 & 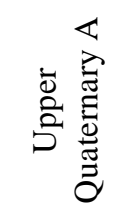 & 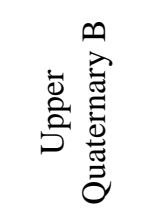 \\
\hline & $4.33 \mathrm{MY}$ & $3.5 \mathrm{MY}$ & $3.4 \mathrm{MY}$ & $2.8 \mathrm{MY}$ & $2.3 \mathrm{MY}$ & $2 \mathrm{MY}$ & $1.8 \mathrm{MY}$ & $1.3 \mathrm{MY}$ & $0.75 \mathrm{MY}$ & $0.63 \mathrm{MY}$ & $0.5 \mathrm{MY}$ & $0.3 \mathrm{MY}$ & $0.15 \mathrm{MY}$ \\
\hline 1 & & & & & $x$ & $x$ & $x$ & $?$ & $?$ & $x$ & $x$ & $x$ & $x$ \\
\hline 2 & & & & & & & & & & $?$ & $?$ & $?$ & $x$ \\
\hline 3 & & & & & & & & & & & & & $x$ \\
\hline 4 & & $?$ & $x$ & $x$ & $x$ & $x$ & $x$ & $x$ & $x$ & $x$ & & & \\
\hline 5 & & & & & & & & & & & & & $x$ \\
\hline 6 & \multicolumn{13}{|c|}{ NA } \\
\hline 7 & \multicolumn{13}{|c|}{ NA } \\
\hline 8 & $?$ & $x$ & & $x$ & $x$ & $x$ & $x$ & $x$ & $x$ & $x$ & 20 & $x$ & $x$ \\
\hline 9 & \multicolumn{13}{|c|}{ NA } \\
\hline 10 & & & & & $x$ & $x$ & $x$ & $x$ & $x$ & $x$ & $x$ & $x$ & $?$ \\
\hline 11 & & & $?$ & $x$ & $x$ & $x$ & $x$ & $x$ & $x$ & $x$ & $x$ & $x$ & $x$ \\
\hline 12 & & & & & & & & & $?$ & $?$ & $x$ & $x$ & \\
\hline 13 & \multicolumn{13}{|c|}{ NA } \\
\hline 14 & & & & & & & $?$ & $?$ & $?$ & $?$ & $?$ & $?$ & $x$ \\
\hline 15 & & & & & & & $x$ & $x$ & $x$ & $x$ & $x$ & $x$ & $x$ \\
\hline 16 & & & & & & & $?$ & $?$ & $?$ & $?$ & $x$ & $x$ & $x$ \\
\hline 17 & & & & $x$ & $x$ & $x$ & $x$ & $x$ & $x$ & $x$ & & & \\
\hline 18 & & & & $?$ & $x$ & $x$ & $x$ & $x$ & $x$ & $x$ & $?$ & $?$ & \\
\hline 19 & & & & & $?$ & $?$ & $x$ & $x$ & $x$ & $x$ & $x$ & $?$ & \\
\hline 20 & & & $?$ & $?$ & $?$ & $?$ & $x$ & $x$ & $x$ & $x$ & $x$ & & \\
\hline
\end{tabular}




\begin{tabular}{|c|c|c|c|c|c|c|c|c|c|c|c|c|c|}
\hline \multirow{3}{*}{$\begin{array}{l}0 \\
0 \\
0 \\
\bar{\Xi} \\
0 \\
0 \\
z \\
0 \\
\sum \\
\sum\end{array}$} & \multicolumn{13}{|c|}{ Time of Mud Flows } \\
\hline & 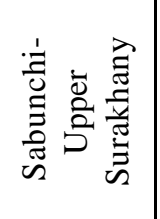 & 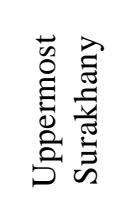 & 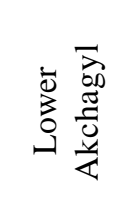 & 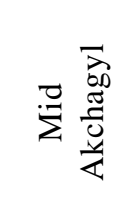 & 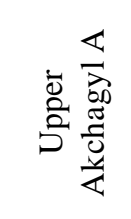 & 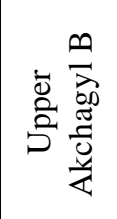 & 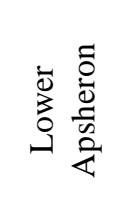 & 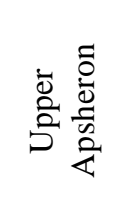 & 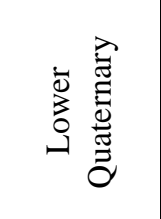 & 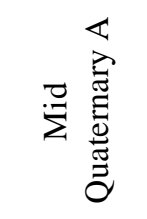 & 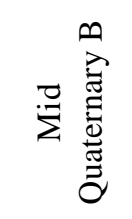 & 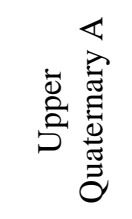 & 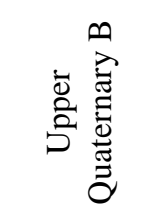 \\
\hline & $4.33 \mathrm{MY}$ & $3.5 \mathrm{MY}$ & $3.4 \mathrm{MY}$ & $2.8 \mathrm{MY}$ & $2.3 \mathrm{MY}$ & $2 \mathrm{MY}$ & $1.8 \mathrm{MY}$ & $1.3 \mathrm{MY}$ & $0.75 \mathrm{MY}$ & $0.63 \mathrm{MY}$ & $0.5 \mathrm{MY}$ & $0.3 \mathrm{MY}$ & $0.15 \mathrm{MY}$ \\
\hline 21 & \multicolumn{13}{|c|}{ NA } \\
\hline 22 & & & ? & ? & ? & ? & ? & ? & $x$ & & ? & $x$ & $x$ \\
\hline 23 & & & $?$ & $?$ & $?$ & ? & ? & $?$ & $x$ & & $x$ & $x$ & $x$ \\
\hline 24 & & & & $?$ & $x$ & $x$ & $\mathbf{x}$ & $x$ & $x$ & $\mathbf{x}$ & & & \\
\hline 25 & & & & & $x$ & $x$ & $x$ & $\mathbf{x}$ & & & & & \\
\hline 26 & & & & & & & & & & $x$ & $?$ & $?$ & $x$ \\
\hline 27 & & & & & & & ? & ? & $x$ & & $x$ & $x$ & $x$ \\
\hline 28 & & & & & & & & & & $x$ & $x$ & $x$ & $x$ \\
\hline 29 & & & $?$ & $?$ & $?$ & $?$ & $?$ & $?$ & $x$ & & $x$ & $x$ & $x$ \\
\hline 30 & & & 0 & 0 & ? & ? & ? & ? & ? & ? & ? & ? & $x$ \\
\hline 31 & & & $?$ & $?$ & $?$ & $?$ & $?$ & $?$ & $x$ & $x$ & & $x$ & $x$ \\
\hline 32 & & & & $?$ & $?$ & $?$ & $?$ & $?$ & $?$ & $?$ & $?$ & $x$ & $x$ \\
\hline 33 & & & & & & & & & & & $x$ & $x$ & $x$ \\
\hline 34 & & & & & & & & & & & & $x$ & $x$ \\
\hline 35 & & & & & & & & & & & $x$ & $x$ & $x$ \\
\hline 36 & & & & & & & & & $x$ & $x$ & $?$ & $x$ & $x$ \\
\hline 37 & & & & & & & & & & & & $?$ & $x$ \\
\hline $38 a$ & & & $?$ & $?$ & $?$ & $?$ & $?$ & $?$ & $x$ & $x$ & $x$ & $x$ & $x$ \\
\hline $38 b$ & & & $?$ & $?$ & ? & ? & $?$ & $?$ & $x$ & $x$ & $x$ & $x$ & $x$ \\
\hline 39 & & & & & & & NA & & & & & & \\
\hline
\end{tabular}




\begin{tabular}{|c|c|c|c|c|c|c|c|c|c|c|c|c|c|}
\hline \multirow{3}{*}{ 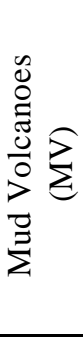 } & \multicolumn{13}{|c|}{ Time of Mud Flows } \\
\hline & 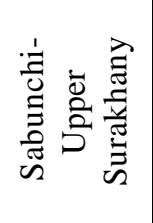 & 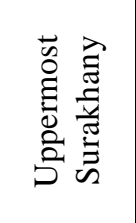 & 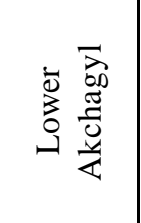 & 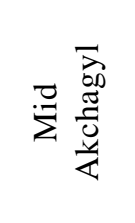 & 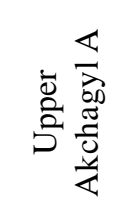 & 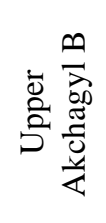 & 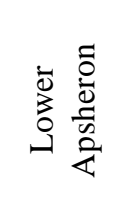 & 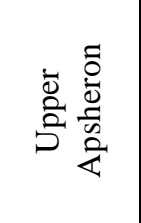 & 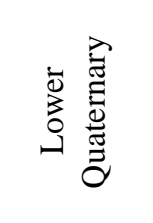 & 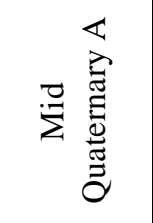 & 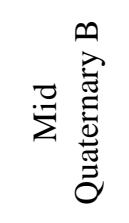 & 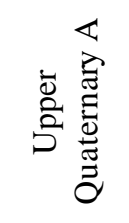 & 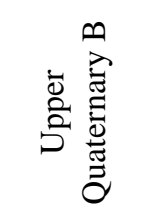 \\
\hline & $4.33 \mathrm{MY}$ & $3.5 \mathrm{MY}$ & $3.4 \mathrm{MY}$ & $2.8 \mathrm{MY}$ & $2.3 \mathrm{MY}$ & $2 \mathrm{MY}$ & $1.8 \mathrm{MY}$ & $1.3 \mathrm{MY}$ & $0.75 \mathrm{MY}$ & $0.63 \mathrm{MY}$ & $0.5 \mathrm{MY}$ & $0.3 \mathrm{MY}$ & $0.15 \mathrm{MY}$ \\
\hline 40 & & & & & & & & & & & $x$ & & $x$ \\
\hline 41 & \multicolumn{13}{|c|}{ NA } \\
\hline 42 & & & & & & & & & $?$ & $?$ & $?$ & $?$ & $x$ \\
\hline 43 & & & & & & & & & $?$ & $?$ & $?$ & $?$ & $x$ \\
\hline 44 & & & & & & & & & & $?$ & $x$ & $x$ & $x$ \\
\hline 45 & & & & & & & & & & $?$ & $x$ & $x$ & $x$ \\
\hline 46 & & & $?$ & $?$ & $?$ & $?$ & $?$ & $?$ & $?$ & $?$ & $?$ & $?$ & $x$ \\
\hline 47 & & & & & & & $?$ & $?$ & $x$ & $?$ & $?$ & $x$ & $x$ \\
\hline 48 & & & & & & & & & $?$ & $?$ & $?$ & $?$ & $x$ \\
\hline 49 & & & & & & & & & $x$ & $x$ & $x$ & $?$ & $x$ \\
\hline 50 & & & & & & & & & $x$ & & $x$ & & $x$ \\
\hline 51 & \multicolumn{13}{|c|}{ NA } \\
\hline 52 & \multicolumn{13}{|c|}{ NA } \\
\hline 53 & \multicolumn{13}{|c|}{ NA } \\
\hline 54 & & & & $?$ & & & $x$ & $x$ & $x$ & $x$ & $?$ & $?$ & $x$ \\
\hline 55 & & & & & $?$ & $?$ & $?$ & $?$ & $?$ & $x$ & & & $x$ \\
\hline 56 & & & $?$ & $?$ & $x$ & $?$ & $?$ & $?$ & $x$ & $?$ & $x$ & & $x$ \\
\hline 57 & & & & & $?$ & $?$ & $x$ & $x$ & $x$ & $x$ & $x$ & $x$ & $x$ \\
\hline 58 & \multicolumn{13}{|c|}{ NA } \\
\hline 59 & & & & & $?$ & $?$ & $?$ & $?$ & $?$ & $?$ & & & $x$ \\
\hline
\end{tabular}




\begin{tabular}{|c|c|c|c|c|c|c|c|c|c|c|c|c|c|}
\hline \multirow{3}{*}{ 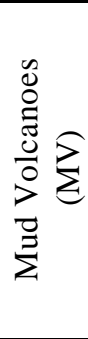 } & \multicolumn{13}{|c|}{ Time of Mud Flows } \\
\hline & 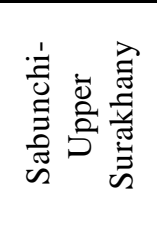 & 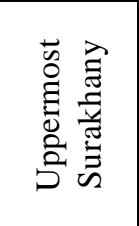 & 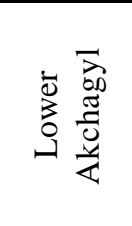 & 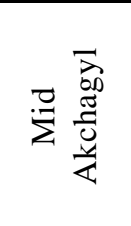 & 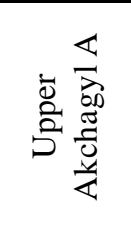 & 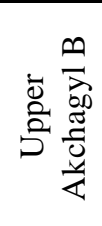 & 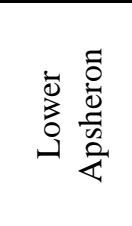 & 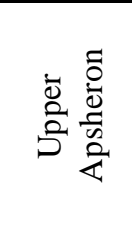 & 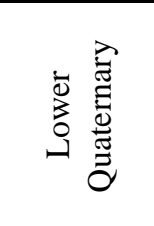 & 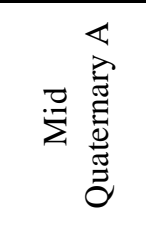 & 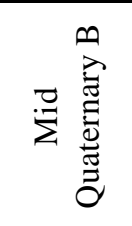 & 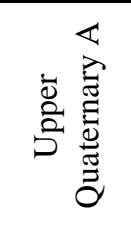 & 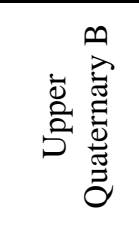 \\
\hline & $4.33 \mathrm{MY}$ & $3.5 \mathrm{MY}$ & $3.4 \mathrm{MY}$ & $2.8 \mathrm{MY}$ & $2.3 \mathrm{MY}$ & $2 \mathrm{MY}$ & $1.8 \mathrm{MY}$ & $1.3 \mathrm{MY}$ & $0.75 \mathrm{MY}$ & $0.63 \mathrm{MY}$ & $0.5 \mathrm{MY}$ & $0.3 \mathrm{MY}$ & $0.15 \mathrm{MY}$ \\
\hline 60 & & & & & & & $?$ & $x$ & $?$ & $x$ & $x$ & $x$ & $x$ \\
\hline 61 & & & & & & & & & & $?$ & $?$ & $?$ & $x$ \\
\hline 62 & & & & & $?$ & $?$ & $?$ & $?$ & $?$ & $?$ & & & $x$ \\
\hline 63 & & & & ? & ? & $?$ & ? & ? & ? & $x$ & & $x$ & $x$ \\
\hline 64 & & & & & & & $?$ & $?$ & $x$ & $x$ & $x$ & $?$ & $x$ \\
\hline 65 & & & & & & & $\times$ & $\times$ & $?$ & & $?$ & $?$ & $x$ \\
\hline 66 & & & & & $?$ & $?$ & $x$ & $x$ & $x$ & & $x$ & $?$ & $x$ \\
\hline 67 & & & & & & & & & & $x$ & & & $x$ \\
\hline 69 & & & $?$ & $?$ & $?$ & & $x$ & $x$ & $x$ & & & & $x$ \\
\hline 70 & & & & & & & & $x$ & $x$ & $x$ & $x$ & & $x$ \\
\hline 71 & & & $x$ & $x$ & $x$ & $x$ & $x$ & $x$ & & & $x$ & & \\
\hline 72 & & & & & & & & & $x$ & $x$ & $x$ & & $x$ \\
\hline 73 & & & & & & & $x$ & & & $x$ & $x$ & $x$ & $x$ \\
\hline 74 & & & & & & & $?$ & $\times$ & $?$ & $?$ & & & $x$ \\
\hline 75 & & & & & & $?$ & $?$ & $?$ & $x$ & & $x$ & & $x$ \\
\hline 76 & & & & & $?$ & $?$ & $?$ & & & & & & $x$ \\
\hline 77 & & & & & & $x$ & $?$ & $?$ & $x$ & $x$ & $x$ & $x$ & $x$ \\
\hline 78 & & & & & & & & & & $?$ & $?$ & $?$ & $x$ \\
\hline 79 & & & & & & & & & & & & & $x$ \\
\hline 80 & & & & & & & NA & & & & & & \\
\hline
\end{tabular}




\begin{tabular}{|c|c|c|c|c|c|c|c|c|c|c|c|c|c|}
\hline \multirow{3}{*}{ 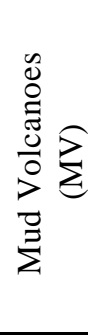 } & \multicolumn{13}{|c|}{ Time of Mud Flows } \\
\hline & 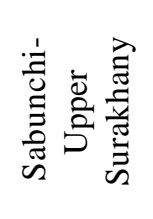 & 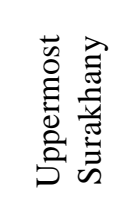 & 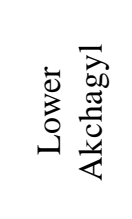 & 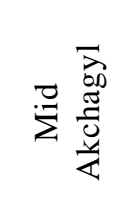 & 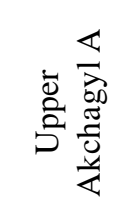 & 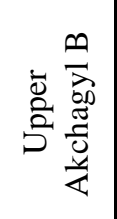 & 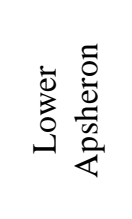 & 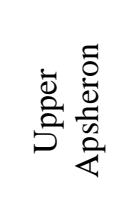 & 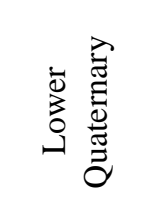 & 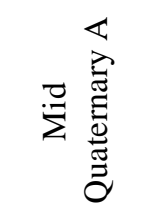 & 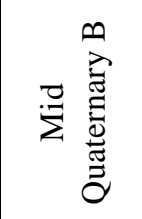 & 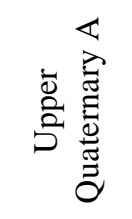 & 芯悹 \\
\hline & $4.33 \mathrm{MY}$ & $3.5 \mathrm{MY}$ & $3.4 \mathrm{MY}$ & $2.8 \mathrm{MY}$ & $2.3 \mathrm{MY}$ & $2 \mathrm{MY}$ & $1.8 \mathrm{MY}$ & $1.3 \mathrm{MY}$ & $0.75 \mathrm{MY}$ & $0.63 \mathrm{MY}$ & $0.5 \mathrm{MY}$ & $0.3 \mathrm{MY}$ & $0.15 \mathrm{MY}$ \\
\hline 81 & & & & & & & $?$ & $x$ & $x$ & $x$ & $x$ & $x$ & $x$ \\
\hline 68 & & & & & & & $?$ & ? & ? & ? & & & $x$ \\
\hline 83 & & & & & & & & ? & ? & $?$ & & & $x$ \\
\hline 84 & & & & & & & ? & $?$ & $?$ & $?$ & & & $x$ \\
\hline 85 & & & & & $x$ & & $x$ & & $x$ & $x$ & $?$ & $?$ & $?$ \\
\hline 82 & \multicolumn{13}{|c|}{ NA } \\
\hline 86 & & & & & & & & & & $x$ & $x$ & & $x$ \\
\hline 87 & $x$ & $x$ & $x$ & $x$ & $x$ & $x$ & $x$ & $x$ & $x$ & $x$ & $x$ & $x$ & $x$ \\
\hline 89 & \multicolumn{13}{|c|}{ NA } \\
\hline 90 & & & & & & & $x$ & $x$ & & & & & $x$ \\
\hline 88 & & & & & $?$ & $?$ & $?$ & $?$ & $x$ & $x$ & $x$ & $x$ & $x$ \\
\hline 91 & & & & & $?$ & ? & & & ? & ? & ? & ? & $x$ \\
\hline 92 & & & & & $?$ & $?$ & $x$ & $x$ & $x$ & $x$ & $x$ & $x$ & $x$ \\
\hline 93 & & & & & & & & & & & & & $x$ \\
\hline 94 & & & & & & & & & $?$ & $?$ & $?$ & $x$ & $x$ \\
\hline 95 & & & & & $?$ & $?$ & $?$ & $?$ & $x$ & $x$ & $x$ & $x$ & $x$ \\
\hline 96 & & & & & & & & & $?$ & $?$ & & $x$ & $x$ \\
\hline 97 & & & & & & & $?$ & $?$ & $?$ & $x$ & & $x$ & $x$ \\
\hline 98 & $?$ & $?$ & $?$ & & & & & & & $x$ & & & $x$ \\
\hline 99 & \multicolumn{13}{|c|}{ NA } \\
\hline
\end{tabular}




\section{APPENDIX B}

\section{LOCATION MAP FOR MUD VOLCANOES PRESENTED IN THE DATABASE}

\section{Legend:}

\begin{tabular}{|c|c|}
\hline 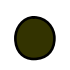 & Mud volcano \\
\hline 15 & $\begin{array}{l}\text { Number of the mud volcano } \\
\text { according to the database }\end{array}$ \\
\hline
\end{tabular}




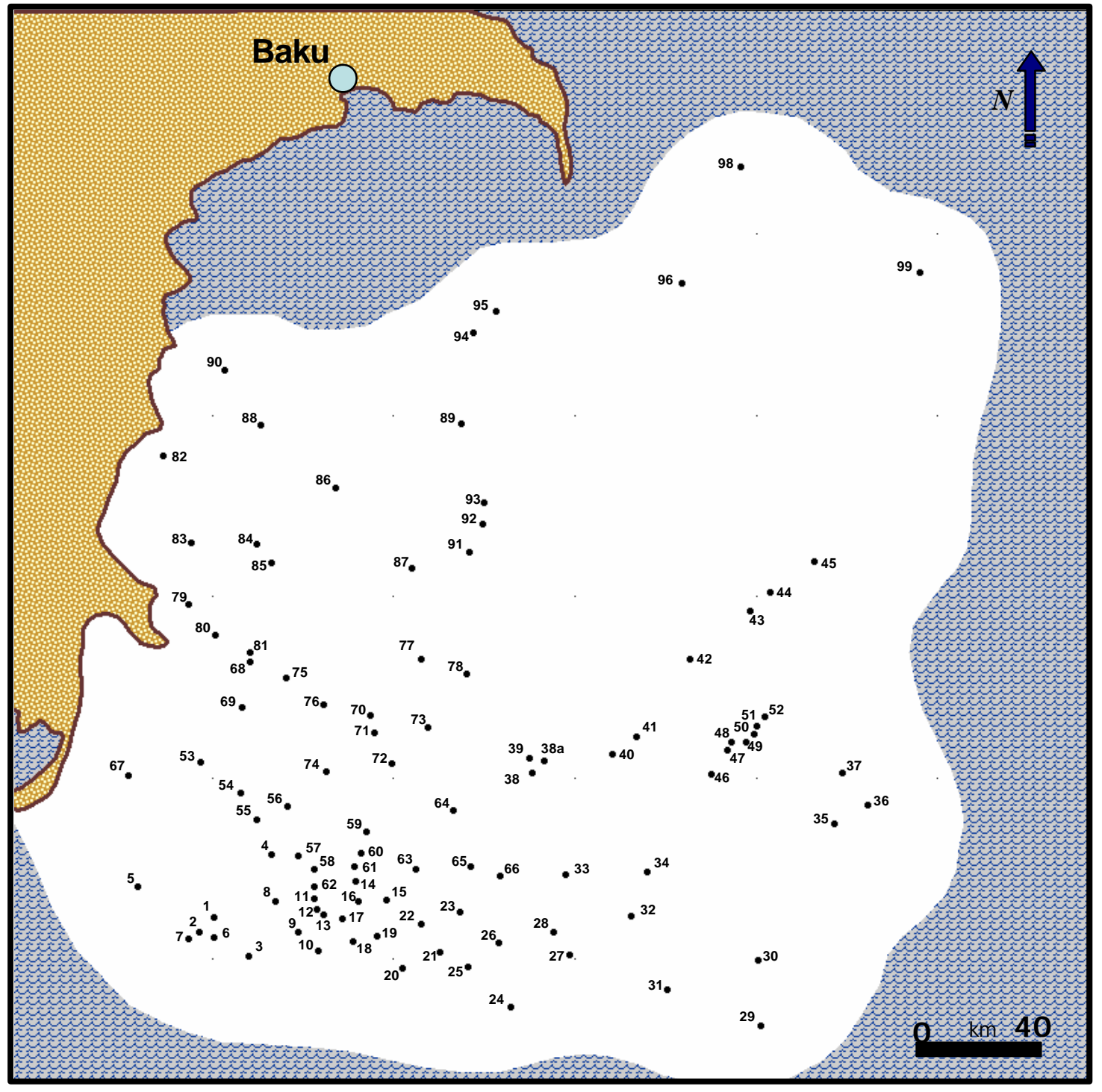




\section{VITA}

Name

Mailing Address

Educational Background

Professional Organization

Experience
Mehdi Yusifov

18 Gulbala Aliyev, apt. \# 1, Baku, Azerbaijan 370003

B.S. in Exploration Geology, Azerbaijan State Oil Academy, June 2000.

M.S. in Geology,

Texas A\&M University, August 2004.

American Association of Petroleum Geologist (AAPG), Society of Exploration Geophysicist (SEG), Geological Society of America (GSA).

Laboratory Assistant Institute of Geology, Azerbaijan Academy of Science, October 1998 - July 2000

Research Assistant Ocean Drilling Program, Texas A\&M University, College Station, TX, January 2003 - December 2003 